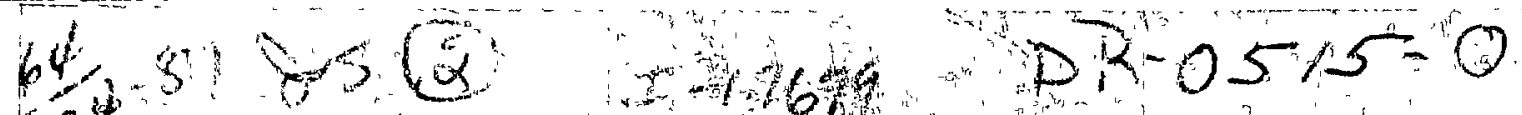
2 \&

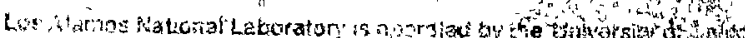

LA. $10159-1 \mathrm{LW}$

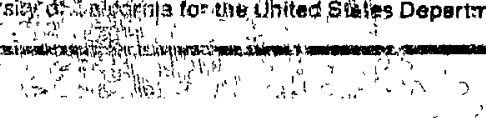

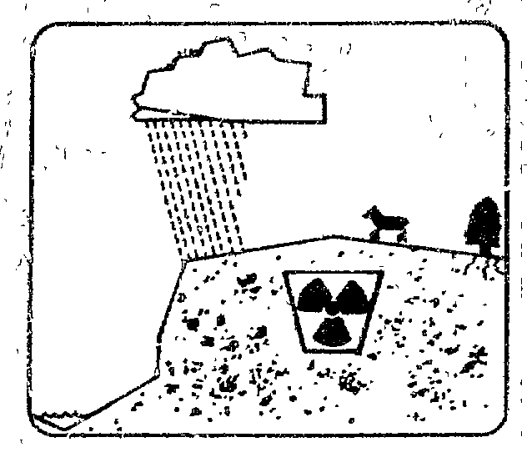

\title{
RADIOACTVE WASTE MANAGEMENT PROGRAM
}

DISTRIBUTION OE RADIONUCLIDES AND WATER IN BANDELIER TUFF BENEATH A FORMER LOS ALAMOS LIOUID WASTE DISPOSAL SITE AFTER 33 YEARS

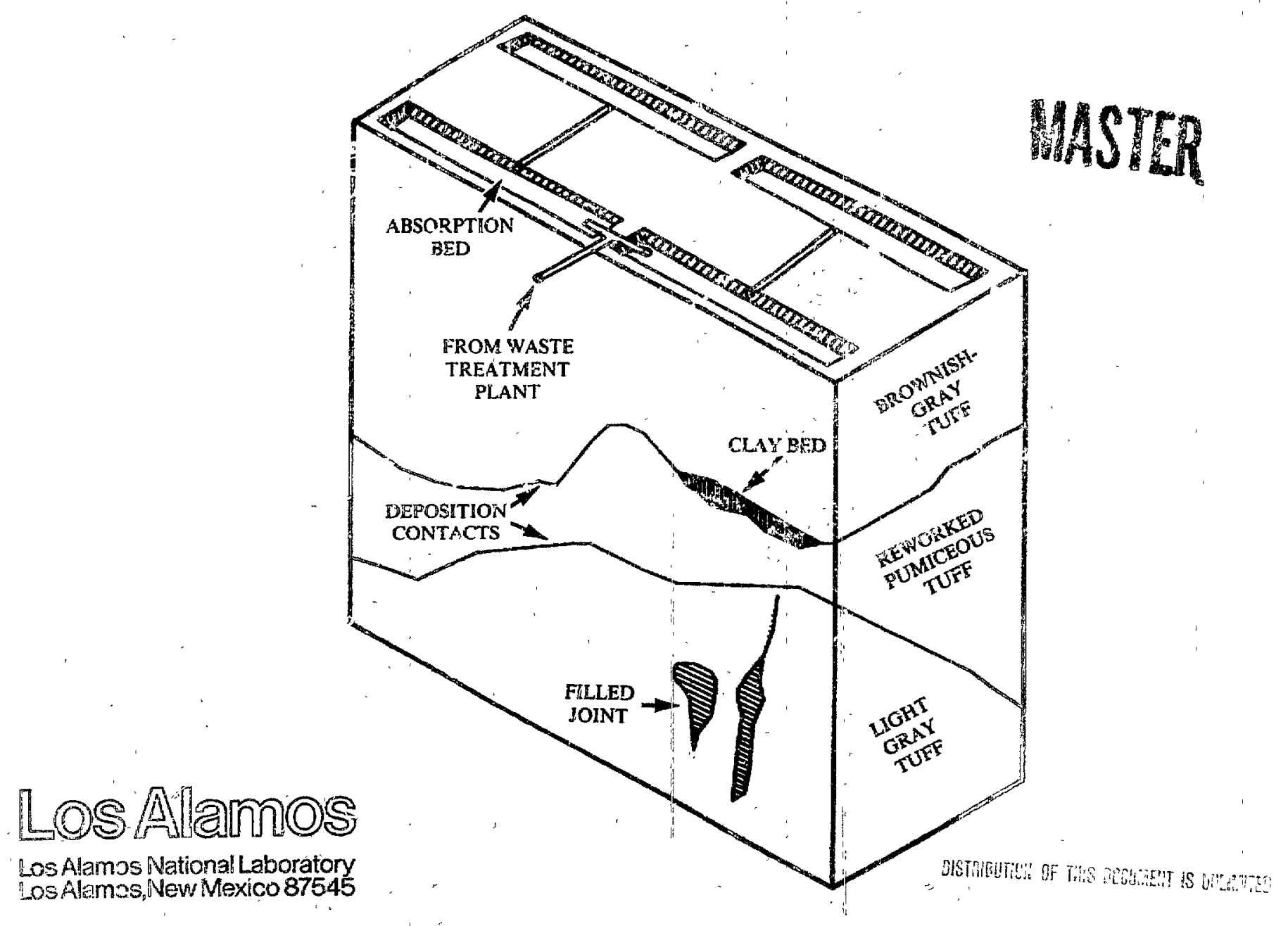




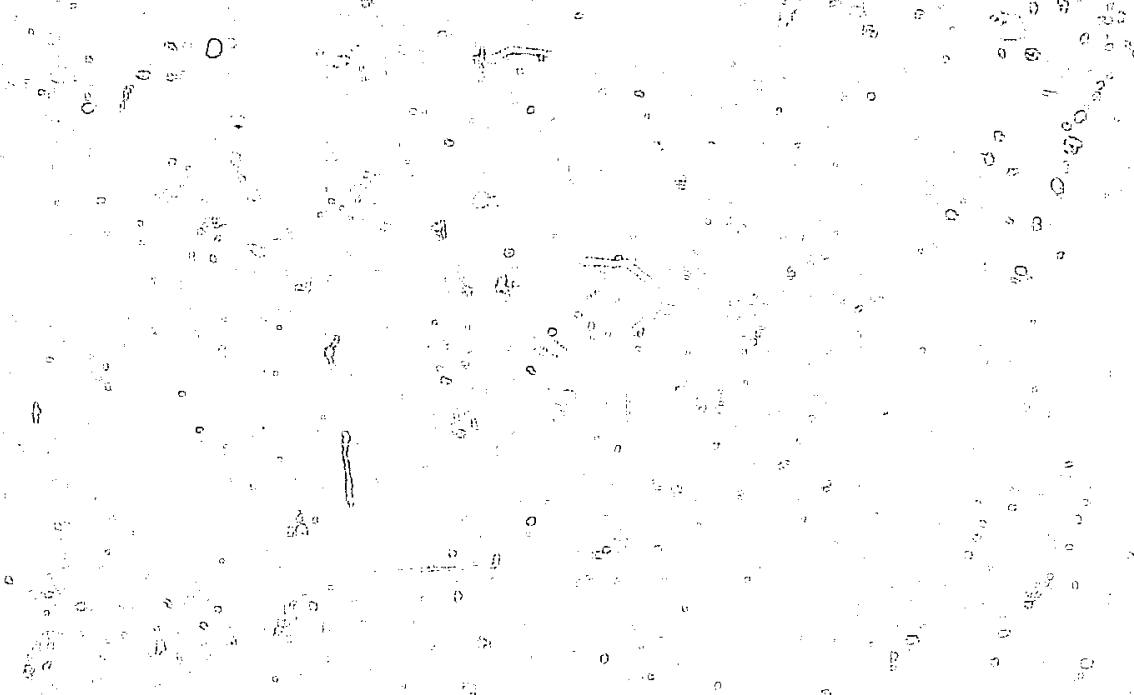

is

This wolk was supported by the $U$.S. Departmient of Energy, Office of Vat ional Low Level Waste Management Frogram.<smiles>C=CC=CC=C</smiles>
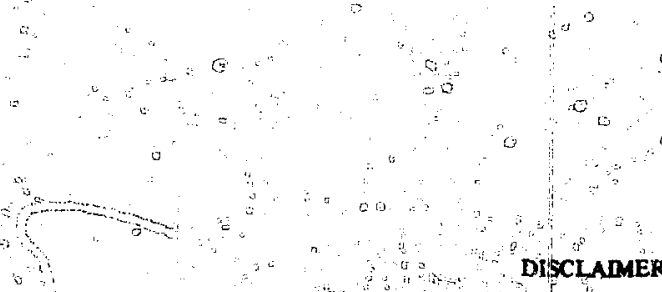

This repart was prepared as an acoount of work shonoted by an agency of the United States Governenent. Neither the United States Sonemment for any sibncy thereof, Doo any of their tmployen, nakes any

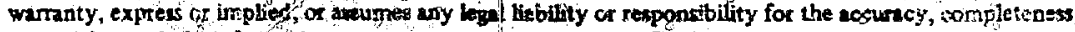
or befuines of say information, apperatus, product; ar proces aieclosed, or represents that its use would not infringe privztely owned rights. Referenice harelis to any spectic commercial peoduct, process, ar

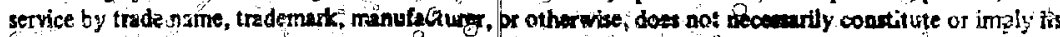
endorsement, eccomrieridation, or fordif oy the linited States Goveinment or anyagency therion. The

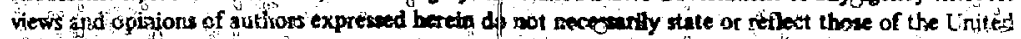
States Coverimeit or any agency thereof. 


\title{
Distribution of Radionuciides and Water in Bandelier Tuff Beneath a Former Los Alamos Liquid Waste Disposal Site After 33 Years
}

\author{
J. W. Nyhan \\ W. J. Herrera \\ B. J. Drennon \\ M. L. Wheeler \\ W. V. Abeele \\ J.W. Booth \\ G. Trujillo \\ W. D. Purtymun
}

\section{DISCLAIMER}

\begin{abstract}
This report was prepared as an account of work sponsored by an agency of the United States Government. Neither the United States Government nor any agency thereof, nor any of their employees, makes any warranty, express or implied, or assumes any legal liability or responsibility for the accuracy, completeness, or usefulness of any information, apparatus, product, or process disclosed, or represents that its use would not infringe privately owned rights. Reference herein to any specific commercial product, process, or service by trade name, trademark, manufacturer, or otherwise does not necessarily constitute or imply its endorsement, recommendation, or favoring by the United States Government or any agency thereof. The views and opinions of authors expressed herein do not necessarily state or reflect those of the United States Government or any agency thereof.
\end{abstract}

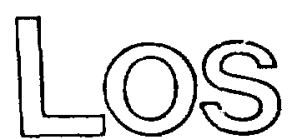




\title{
DISTRIBUTION OF RADIONUCLIDES AND WATER \\ IN BANDELIER TUFF BENEATH A FORMER LOS ARAMOS LIQUID WASTE DISPOSAL SITE AFTER 33 YEARS
}

\author{
by \\ J. W. Nyhan, B. J. Drennon, W. V. Abeele, M. L. Wheeler, \\ W. D. Purtymun, G. Trujillo, W. J. Herrera, and J. W. Booth
}

\begin{abstract}
The distribution of radionuclides and water in Bandelier Tuff beneath a former liquid waste disposal site at Los Alamos was inve',tigated. The waste use history of the site was described, as well as several pertinent laboratory and field studies of water and radionuclide migration in Bandelier Tuff. The distribution of plutonium, ${ }^{241} \mathrm{Am}$, and water was determined in a set of about 800 tuff samples collected to sampling depths of $30 \mathrm{~m}$ beneath two absorption beds. These data were then related to site geohydrologic data. Water and radionuclide concentrations found after 33 years were compared with the results of similar studies previously performed at this site, and the implications of these comparisons are discussed relative to nuclear waste management.
\end{abstract}

\section{INTRODUCTION}

In late 1943, a site with the primary responsibility for the purification of plutonium was established at Los Alamos. Because of urgency, Jimited construction time, and the lack of information on the resulting radioactive wastes, it was initially decided to dispose of radioactive wastes in several ways. Untreated liquid wastes were at first discharged into canyons, into underground storage tanks, and into absorption beds filled with gravel and cobble (Abrahams 1962, Rogers 1977), such as the beds at Area $T$ in the DP Wesi site of the Los Alamos National Laboratory.

The interaction of radionuclides in these liquid wastes with local soils and geologic materials was initially studied in the laboratory. Cores of Bandelier Tuff collected at Los Alamos were contaminated with waste solutions of plutonium, essentially all of which was retained in the top few millimeters of the core even after subsequent leaching of the sorbed plutonium (Christenson et al. 1958). In 1959, a field study was initiated to determine the distribution of plutonium previously discharged into an absorption bed at Area T (Christenson and Thomas 1962). Unlike the previous laboratory study, the 1959 field study showed that plutonium species penetrated as far as $8.5 \mathrm{~m}$ into Bandelier Tuff and that this penetration coul take place along fissures in the tuff. High percentages of clays, deposited randomly in the tuff by local weathering, were speculated to have absorbed plutonium species, resulting in localized areas of high plutonium concentrations.

In 1974, a detailed series of laboratory studies was initiated with crushed and intact Bandelier Tuff at Argonne National Laboratory, which showed that waste and aqueous solutions of plutonium and americium exhibited anomalous migration behavior (Fried et al. 1975, 1976, 1977, and 1978). This research demonstrated that plutonium appeared to exist in two forms, one of which (probably the hydrolyzed form) migrated much more rapidly than the "ionic" form when conducted by aqueous percolation. Much to the surprise of the waste man- 
agement community, the experimental results suggested a predicted penetration rate of the more mobile plutonium phase of about $217 \mathrm{~cm} / \mathrm{yr}$ when accompanied by unsaturated water flow in the tuff (Fried et al. 1975)!

The objective of this field study was to determine the distribution of plutonium, ${ }^{241} \mathrm{Am}$, and water beneath two absorption beds at Area $T$ in Los Alamos as a function of depth and of the waste use history of each absorption bed. The vertical distributions of radionuclides and water were related to the occurrences of fractures and geologic units of tuff in each protile. The findings of this field study are also compared with the results of other studies performed at this site and are discussed relative to the long-term migration of water in the tuff at this site.

\section{WASTE USE HISTORY AND DESCRIP- TION OF STUDY SITE}

The absorption beds at Area $\mathrm{T}$ are the oldest used for the disposal of liquid wastes at Los Alamos (Fig. 1) and have been described in detail (Rogers 1977). After the construction of these 1.2-m-deep, $36.6-\mathrm{m}$ by $6.1-\mathrm{m}$ absorption beds (Fig. 2) was completed in 1945 , they received untreated radioactive liquid wastes from 1945 through 195 ! from DP Site. The DP West liquid waste treatment plant, Building TA-21-35, was installed in 1952 (Fig. 2), largely because the volume of liquids discharged to the beds had exceeded the holding capacity of the absorption beds, despite the fact that the beds had been equipped with a distribution box located between beds 1 and 2 , which ensured that equal volumes of wastes were discharged to these two beds. Approximately $89 \%$ of the $69260 \mathrm{~m}^{3}$ of liquid effluents added to the Area T absorption beds was added between 1945 and 1960 , with the remaining $11 \%$ added in rapidly decreasing amounts until 1967 (Rogers 1977). A new treatment plant, TA-21-257, was built in 1967, which also infrequently discharged treated wastes in to the absorption beds. However, almost all of these treated effluents were discharged to the canyon north of the plant.

Both the addition rate and the type of waste added to the absorption beds changed with time at Area T. About $98 \%$ of the estimated $10 \mathrm{Ci}$ of plutonium discharged to the absorption beds was added as untreated wastes between 1945 and 1952 (HDivision Staff 1974, Rogers 1977). The concentration of plutonium in the estimated $53000 \mathrm{~m}^{3}$ of untreated effluents during this period has been estimated at about $120 \mathrm{dpm}$ plutonium $/ \mathrm{ml}$, with an average fluoride concentration associated with the wastes of $160 \mathrm{ppm}$. However, about $40 \mathrm{~m}^{3}$ of untreated ef- fluents containing large concentrations of ammonium citrate were released into the beds from June 1951 to July 1952, and these wastes contained about $14000 \mathrm{dpm}$ plutonium $/ \mathrm{ml}$ and $200 \mathrm{ppm}$ fluoride. The smallest contributions to the beds came between 1953 and 1967 when about $16000 \mathrm{~m}^{3}$ of treated effluents, containing only about $0.2 \mathrm{dpm}$ plutonium $/ \mathrm{m} \ell$, were discharged to the absorption beds. Although most of the physical and chemical properties of these liquids were described (Rogers 1977), the results of the 1961 study show the pH of the raw wastes usually ranged from 3.0 to 4.0 , with about $50 \%$ of the alpha activity and $75 \%$ of the solids in the raw wastes passing through a $0.45-\mu \mathrm{M}$ millipore filter (Christenson and Thomas 1962). These waste solutions contained an average of $1245 \mathrm{ppm} \mathrm{K}$, $197 \mathrm{ppm} \mathrm{Na}, 57 \mathrm{ppm} \mathrm{Cl}$, and $36 \mathrm{ppm} \mathrm{SO}_{4}$ during one month of daily sampling in this study.

Detailed geologic descriptions of the Area T site were summarized in 1977 (Rogers 1977). The absorption beds were excavated in Unit 3 of the Tshirege Member of the Bandelier Tuff. The upper $3.6 \mathrm{~m}$ of a typical geologic profile consists of a moderately welded, light brownish-gray tuff. This layer is underlain by a 3-m-thick layer of reworked tuff and pumice, which was emplaced contemporaneously with the upper unit in a channel (or low relief) cut into the lower tuff unit. A sharp contact zone is found between this reworked tuff and the lower, moderately welded, light gray tuff unit, which has an approximate thickness of $33 \mathrm{~m}$. This later unit is underlain by a moderately to densely welded tuff, giving a total thickness of Bandelier Tuff in excess of $250 \mathrm{~m}$. The top of the main zone of saturation is about $350 \mathrm{~m}$ below the surface of the mesa.

The saturated hydraulic conductivity of 20 intact tuff samples from the upper unit of tuff at Area $T$, collected adjacent to absorption bed 1, ranged from 0.05 to $0.29 \mathrm{~cm} / \mathrm{h}$ (Nyhan 1979). However, a more detailed description of the geohydrology of Bandelier Tuff was recently reported (Abeele et al. 1981).

\section{ENVIRONMENTAL STUDIES AT AREA T}

The earliest studies at Area T were environmental monitoring surveys. For example, water and suil samples were collected in the absorption beds in 1946 and analyzed for plutonium (Kingsley 1947). These environmental plutonium assays showed large variability: a water sample collected in July assayed at $6780 \mathrm{dpm} \mathrm{Pu/ \ell}$, whereas a similar sample collected in September contained only $100 \mathrm{dpm} \mathrm{Pu} / \ell$. 


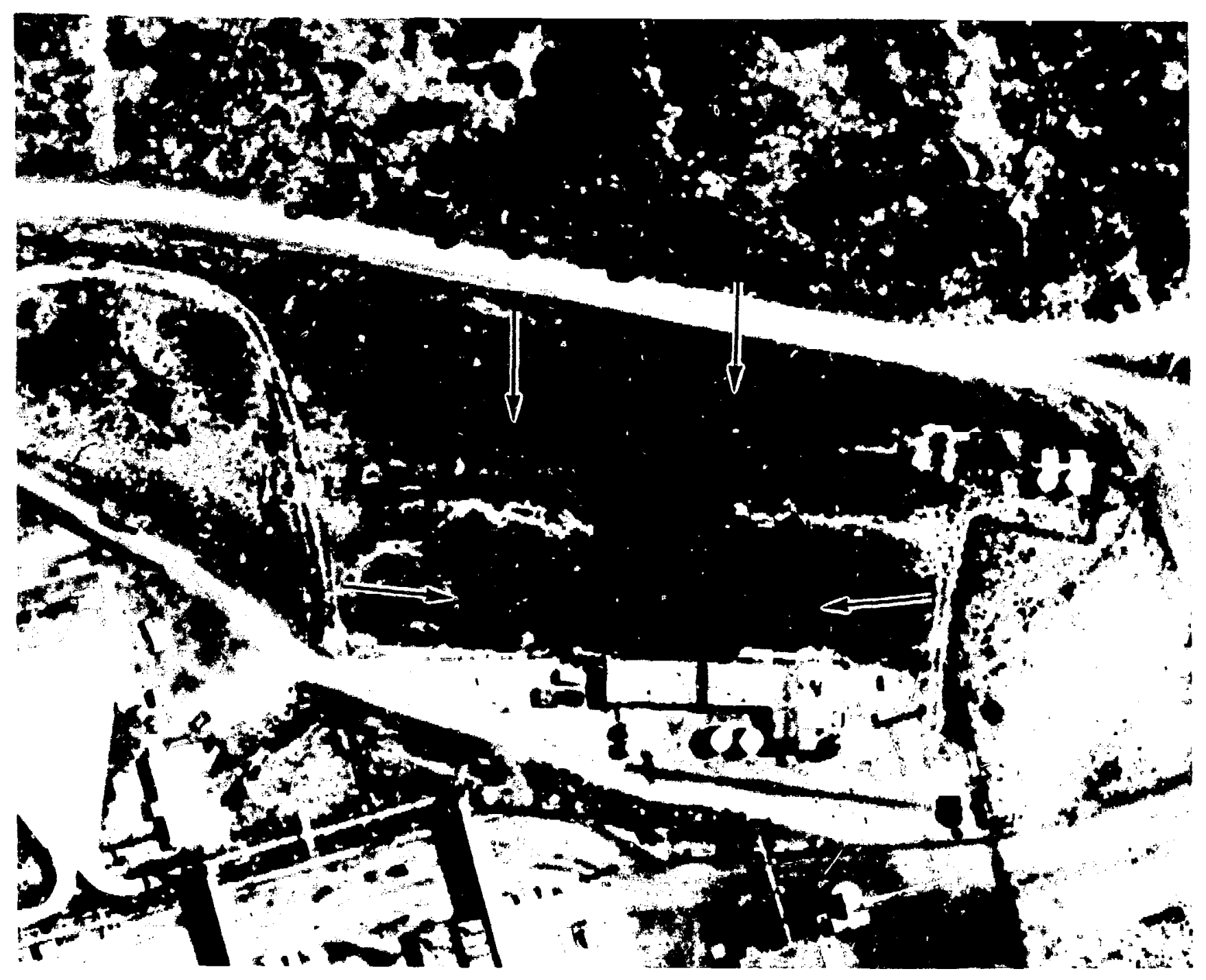

Fig. 1. Aerial photograph of four absorption beds at Area T in 1965 (see Fig. 2a for more detail). 


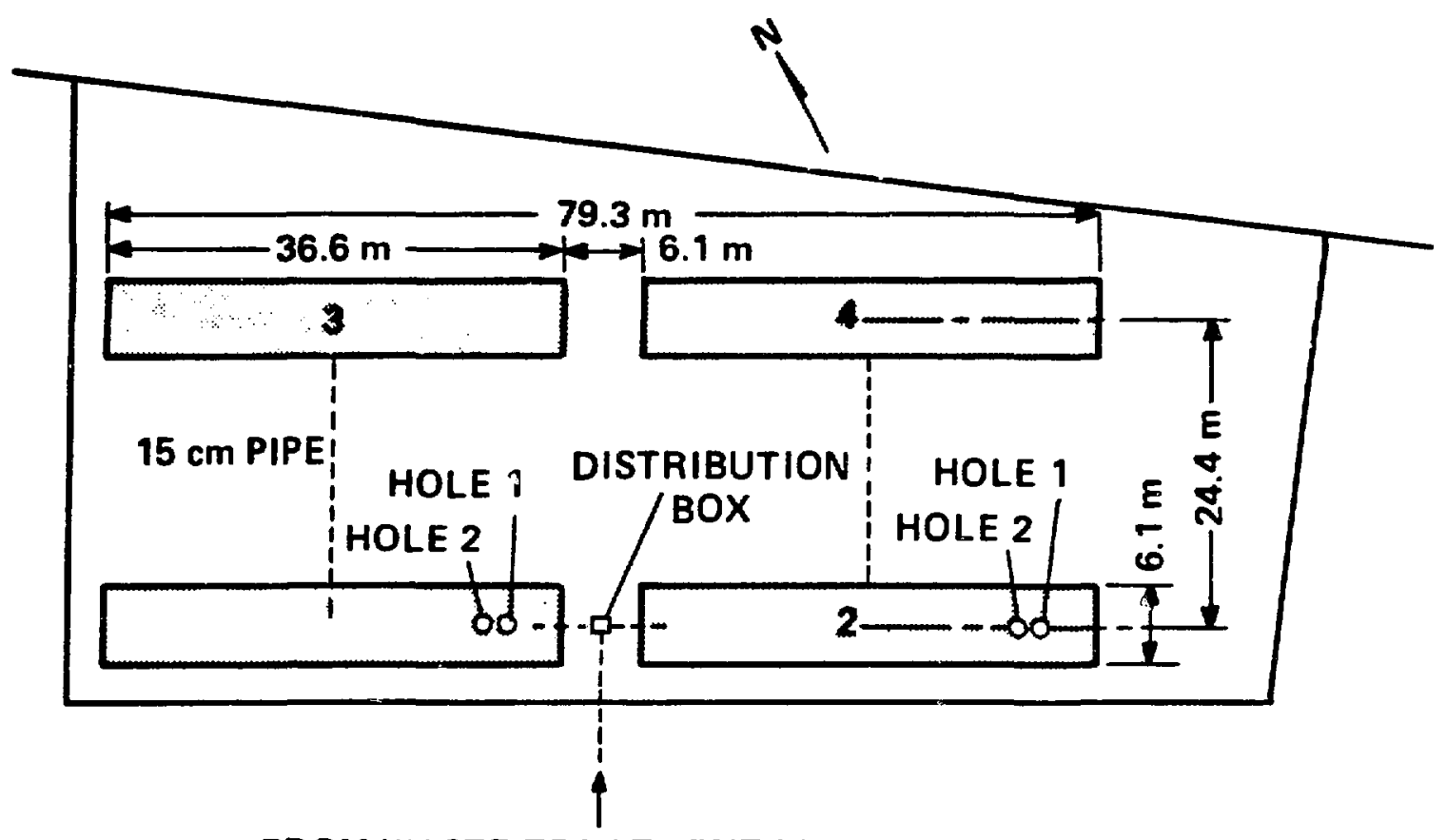

FROM WASTE TREATMENT PLANT

a. Site plan of absorption bed system.

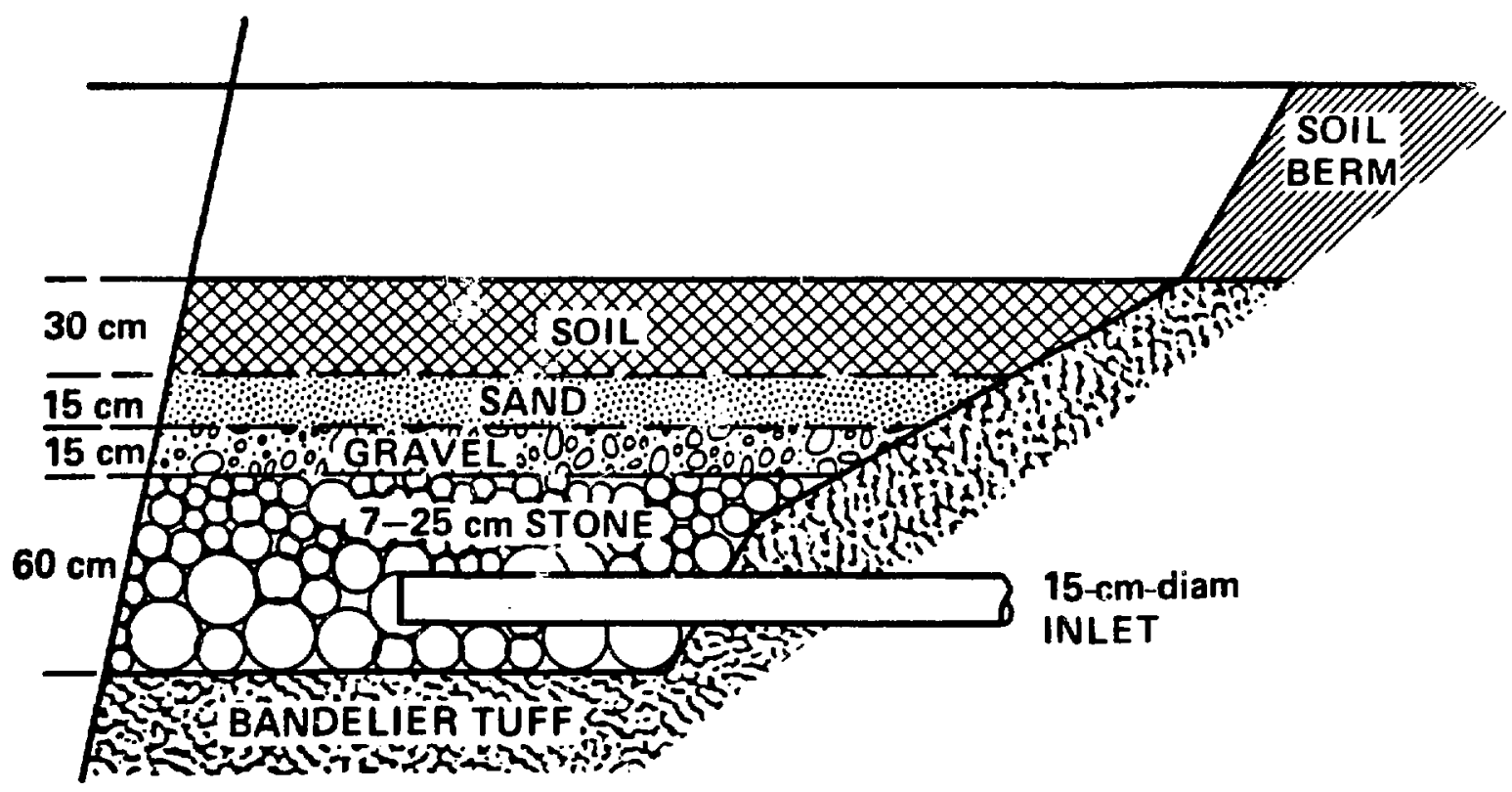

b. Cross section of an absorption bed.

Fig. 2. Design of absorption beds at Area T. 
In 1953, the US Geological Survey (USGS) conducted a preliminary study to determine the vertical distribution of plutonium beneath the absorption beds at Area $T$ because "past information indicated that this particular location has probably received more plutonium contamination from liquid wastes than any other area." (Herman 1954). Five 3- to 6-mdeep holes were drilled in and around the absorption beds, and an effort was made to gather samples at 30$\mathrm{cm}$ intervals using a pick and shovel, a driven pipe, and a drillirg rig with a core barrel. The medium sampled was a conglomeration of soil, sand, gravel, tuff, and rock (Fig. 2), which allowed only fragmentary or no core recovery using the drill rig. Thus, Herman notes that "the bottom of the hole occasionally became contaminated by loose material from near the surface." However, the results of this study indicated that the vertical migration of plutonium occurred within $6 \mathrm{~m}$ of the surface of the absorption beds and that plutonium is readily retained by the components in the bed (Fig. 2). Herman also stated "Penetration of plutonium into the underlying strata is not to be expected."

A joint USGS-Los Alamos National Laboratory study (Abrahams 1963, Christenson and Thomas 1962) was begun in October 1959 at Area T with the construction of a 9.1 -m-deep, 1.8-m-wide, 3.6-m-long caisson on the northwest corner of absorption bed 1 . Twelve horizontal holes were drilled at $61-\mathrm{cm}$-depth intervals and long enough to terminate at about the center of the absorption bed. Liquid samples were collected under vacuum from each hole for radionuclide assays, and soil wate: eterminations were performed in each hole with a neutron moisture gauge. Cuttings from these horizontal caisson holes were collected in the summer of 1959 to estimate the vertical distribution of plutonium in absorption bed 1. Average gross alpha radiation readings in these samples at the $3-\mathrm{m}$ depth were $3003 \mathrm{cpm} / \mathrm{g}$ and gradually decreased to $28 \mathrm{cpm} / \mathrm{g}$ at $\$ .5 \mathrm{~m}$, except for a high concentration $(402 \mathrm{cpm} / \mathrm{g})$ found at the $7.3-\mathrm{m}$ depth. The latter observation was attributed to a known vertical fissure in the tuff at this depth, which allowed wastes from the absorption bed "to drain unchanged to a lower level." (Christenson and Thomas 1962).

After documenting the vertical distribution of radioactivity in the 1959-1960 study, researchers attempted to change the distribution of plutonium beneath absorption bed 1 by adding $10.8 \mathrm{~m}$ of effluent containing plutonium in July 1961 and $9.7 \mathrm{~m}$ of tap water a month later. During and immediately after the releases, a large effort was also expended to characterize the infiltration and movement of water and plutonium in the tuff beneath the absorption bed. Unsaturated water flow was observed from 12 to $30 \mathrm{~m}$ beneath this absorption bed, with about $10 \mathrm{~m}$ of water-saturated tuff occurring above this layer after the addition of the $9.7 \mathrm{~m}$ of tap water.

In 1967, another reconnaissance study was made of the Area T absorption beds (Purtymun 1967). Water samples were again collected from the tuff beneath the bed, and the moisture contents of the tuff were logged at selected depths. Results showed the maximum tuff water contents moved from the $3.7-\mathrm{m}$ depth in August 1961 to the 12-m depth in January 1967. It was again concluded that most of the plutonium was retained in the upper $6 \mathrm{~m}$ of the absorption bed, with some plutonium moving to greater depths through open joints.

Starting in 1974, several cooperative studies were initiated between Argonne National Laboratory and the Los Alamos National Laboratory (Fried et al. 1975, 1976, 1977, 1978). The Argonne workers were performing laboratory research on the migration of plutonium in tuff from Los Alamos, and they desired field validation of their results. Thus, in 1976, core samples were collected at Area $T$ to a minimal depth of $6 \mathrm{~m}$, and the distribution of pluionium and americium in these samples was compared with predicted actinide distributions derived from laboratory studies. Although the laboratory results for plutonium agreed with the field data, americium was found to migrate farther into the tuff in the field than in the laboratory (Fried et al. 1977).

\section{METHODS}

Our field study was initiated in 1978 to determine the vertical distribution of ${ }^{241} \mathrm{Am}$, plutonium, and water beneath the absorption beds at Area $T$. During 1978, two 30.5-m-deep holes were drilled through absorption beds 1 and 2 (Fig. 1). Continuous core samples of the tuff were collected beneath the beds by driving a split-spoon sampler, $60-\mathrm{cm}$ long and 7.6-cm diam, through a $23-\mathrm{cm}$-diam hollow-stem auger. The sampler was driven with either an 180-lb or a 400-lb drop hammer. At the end of each core run, to minify cross-contamination, the auger was advanced to the bottom of the core hole before the next core was collected.

Core samples were cut into $15-\mathrm{cm}$ segments as they were removed from the split spoon, immediately placed in glass jars, and brought back to the laboratory. Each sample was dried for $72 \mathrm{hr}$ at 
$110^{\circ} \mathrm{C}$ to determine soil water. The sample was then crushed in a plastic bag, mixed on a sheet of paper, and assayed for ${ }^{241} \mathrm{Am}$ and plutonium using an $\mathrm{L} \mathrm{x}$ ray and gamma-ray radionuclide assay system described previously (Trujillo et al. 1980, Nyhan et al. 1983). Radionuclide inventories for each hole were determined by multiplying the concentration of either ${ }^{241} \mathrm{Am}$ or plutonium by the total oven-dry weight of tuff in the depth segment for evcry segment in the hole below the gravel-cobble bed bottom and expressing this result as $\mu \mathrm{Ci}$ of radioactivity for each hole.

The inventory of soil water in each hole was calculated from the gravimetric water content and bulk density of all the samples from each hole. The bulk density was calculated from the total oven-dry weight of the tuff sample from each $15-\mathrm{cm}$ core segment and the known sampling volume of the splitspoon sampler. The bulk density was multiplied by the gravimetric water percentage of each sample divided by 100 and by the sampling depth to calculate the total amount of water in each core segment.

Although the hydraulic conductivity $(\mathrm{K})$ of the upper unit of tuff adjacent to bed 1 was determined (Nyhan 1979), we were not able to collect undisturbed samples of tuff within the contact zone between the two tuff units to assay for $K$. Thus, we approximated the value of $\mathrm{K}$ for the contact zone using the data collected in the 1961 Area T siudy (Christenson and Thomas 1962) and the constanthead method according to the following equation:

$$
K=\left(\frac{\mathrm{Q}}{\mathrm{At}}\right)\left(\frac{\mathrm{L}}{\Delta \mathrm{H}}\right) \text {. }
$$

The yolume of water, $Q$, that passed through the contact zone tuff core of area, $A$, and length, $L$, was measured for a known time, $t$, and for a constant hydraulic head difference, $\Delta \mathrm{H}$. The value of $\mathrm{Q}$ was approximated from the difference of the neutron moisture gauge data collected on July 26, 1961, and August 23, 1961, below the contact zone (12.19- to $25.91-\mathrm{m}$ depth), for a tuff core with a radius of $30 \mathrm{~cm}$, corresponding to the estimated radius of investigation of the moisture gauge (Nyhan et al. 1983, Q = $18615 \mathrm{~cm}^{3}$ water). Thus, the estimated values for $A$, $t$, and $\Delta H$ were $2827 \mathrm{~cm}^{2}, 672$ hours, and $969 \mathrm{~cm}$. The thickness, $L$, of the contact zone was estimated from the drilling $\log$ data and the distribution of water beneath bed 1 in $1978(\mathrm{~L}=250 \mathrm{~cm})$.

Soil $\mathrm{pH}$ was determined on a few samples of tuff using a 2:1 water-to-soil ratio so that the effect of the nonradioactive components of the waste solutions on the tuff geochemistry could be partially evaluated.

\section{RESULTS AND DISCUSSION}

The detailed field notes co'lected during the drilling operation at Area $T$ are presented in Tables A-I through A-IV (Appendix A). This information is followed by Appendix $B$, which lists results of the determinations of the sample oven-dry weight, water content, and plutonium and ${ }^{241} \mathrm{Am}$ concentrations for the 800 samples collected in this study.

We will first examine the distribution of radionuclides beneath the absorption beds in 1978 and then, because the movement of water under the beds is the driving force for radionuclide migration, the distribution of water in the tuff will be analyzed. The inventories and vertical distributions of radionuclides and water will then be related to site geohydrologic characteristics and the $\mathrm{pH}$ of selected tuff samples. Our data will then be compared with the results of similar studies performed at Area $T$ in the past, and the temporal changes in water and radionuclide distributions at this site will be discussed.

\section{A. Vertical Distributions of Radionuclides and Water Beneath the Absorption Beds}

The distribution of plutonium and ${ }^{241} \mathrm{Am}$ concentrations as a function of sampling depth is presented for both absorption beds in Figs. 3 and 4. The cobble layer indicated in these figures marks the gravel-cobble layer in the bottom of the original absorption beds (Fig. 2). Although the individual data points are not plotted in these figures, the high degree of detail reflects the fact that this data set represents radionuclide assays on a total of 800 samples!

Radionuclides were generally detected to the bottom of both holes in absorption bed 1, which received the additions of large amounts of tap water and effluents in 1961 to provide the additional driving force for radionuclide migration (Figs. 3 and 4). More specifically, in hole 1 , plutonium was detected to a sampling depth of $30.33 \mathrm{~m}$ and ${ }^{241} \mathrm{Am}+\mathrm{o}$ a depth of $30.48 \mathrm{~m}$. Although the hole 2 samples generally contained smaller radionuclide concentrations than the samples from hole $1,{ }^{241} \mathrm{Am}$ was deteeted to a depth of $30.78 \mathrm{~m}$ and plutonium was found to a sampling depth of $14.48 \mathrm{~m}$ in hole 2 , indicating higher mobility for ${ }^{241} \mathrm{Am}$ than for plutonium under thcse environmental conditions.

The plutonium and ${ }^{241} \mathrm{Am}$ did not penetrate nearly as far into the tuff beneath absorption bed 2 because this bed did not receive additional water in 1961 (Figs. 3 and 4). The minimum sensitivity of analysis (depicted in these figures as a sample plotted 


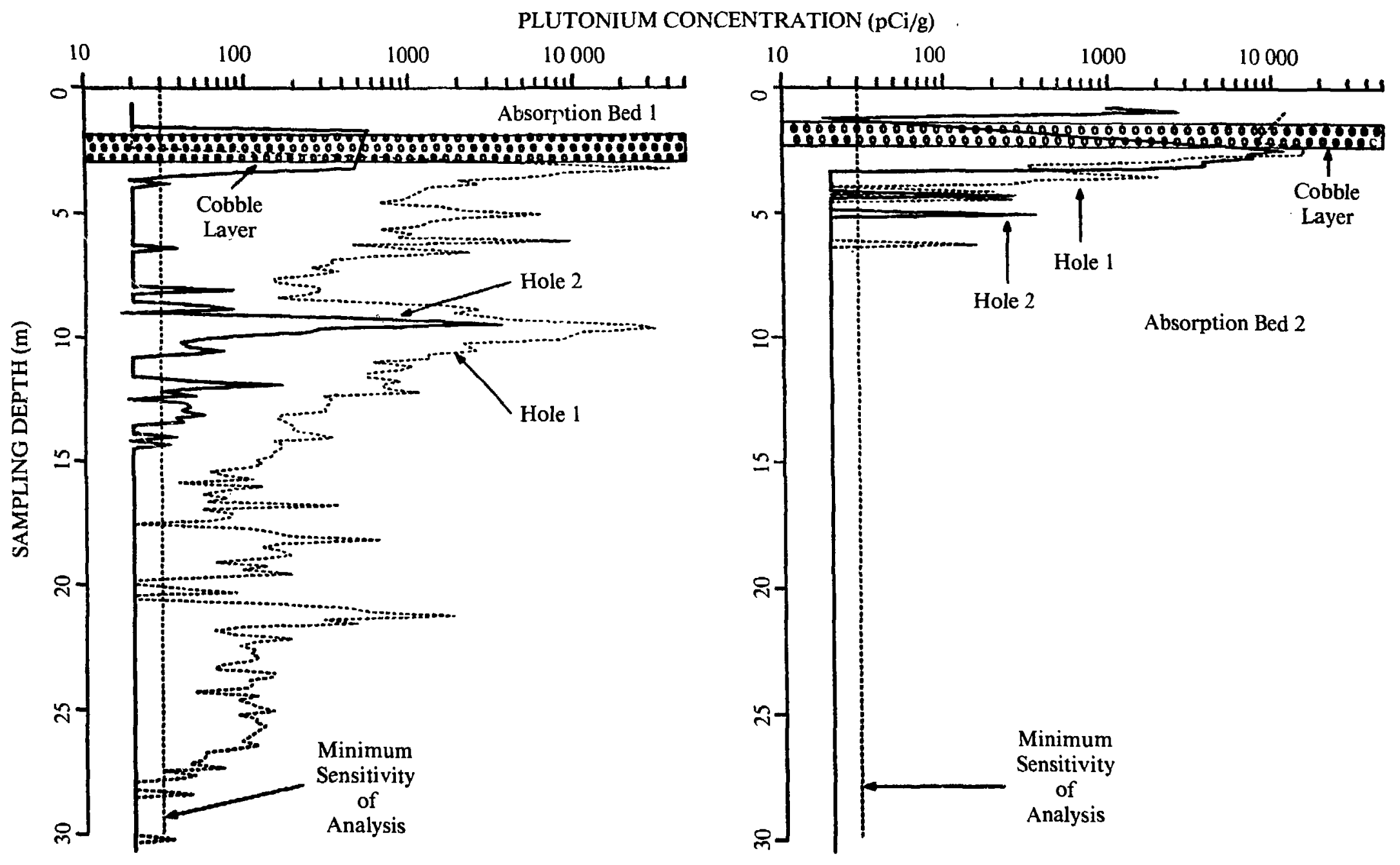

Fig. 3. Concentration of plutonium as a function of sampling depth for absorption beds 1 and 2 in 1978. 
AMERICIUM CONCENTRATION ( $(\mathrm{Ci} / \mathrm{g}$ )

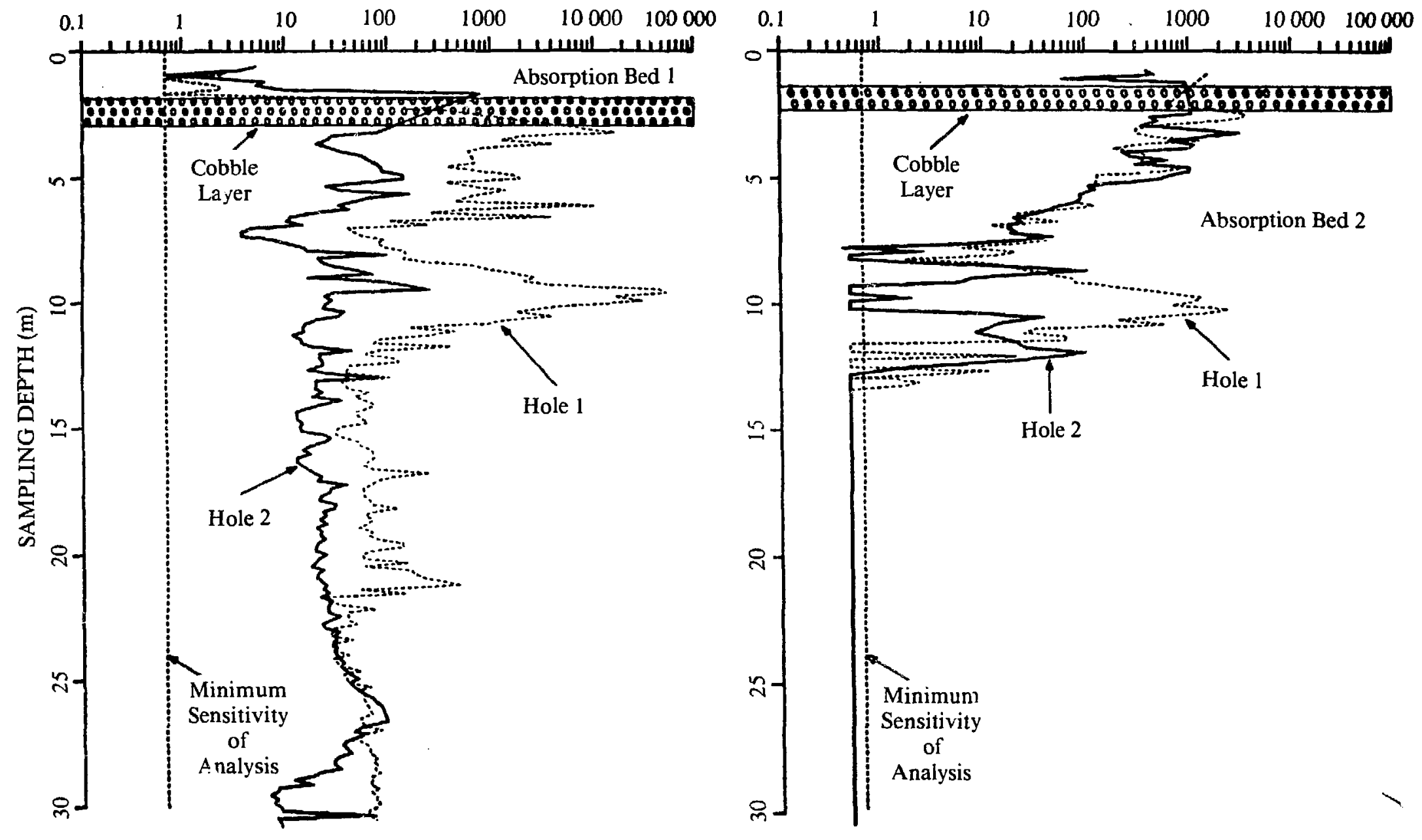

Fig. 4. Concentration of ${ }^{24 !} \mathrm{An}$ ) as a function of sampling depth for absorption beds 1 and 2 in 1978. 
to the left of the minimum sensitivity of analysis line) was reached for tuff samples collected at sampling depths greater than $6.55 \mathrm{~m}$ for plutonium and 13.41 $\mathrm{m}$ for ${ }^{241} \mathrm{Am}$ in hole 1 . Plutonium was detected only to a sampling depth of $5.18 \mathrm{~m}$ in hole 2 and ${ }^{241} \mathrm{Am}$ to a sampling depth of $12.80 \mathrm{~m}$ in this hole, indicating a higher degree of mobility of americium than plutonium in this absorption bed, just as for absorption bed 1. This was also shown for the Area $T$ field data described previously (Fried et al. 1977).

The distribution of water in the tuff (giavimetric water content) beneath the Area $T$ absorption beds is shown as a function of depth below the current land stirface (Fig. 5). The absorption bed 1 profiles showed generally higher tuff water contents than did similar profiles in absorption bed 2, with some samples attaining gravimetric water contents as high as $30 \%$ (Fig. 5), a value very close to saturation (38\%) for Bandelier Tuff. The water content of most of the tuff samples collected in bed 1 was obviously still enhanced relative to the bed 2 samples because of the additions of water in 1961. For example, considering only the samples collected from the 25.15- to 30.48$m$ depth in the hole 1 profiles, the absorption bed 1 average tuff water content was $7.66 \%$, whereas the average gravimetric water content for similar bed 2 samples was only $5.89 \%$.

\section{B. Correlations of Radionuclide and Water Content Distributions with Site Geohydrology}

Although all of the variations in soil water content (Fig. 5) and radionuclide concentrations (Figs. 3 and 4) cannot be explained, several changes can be accounted for based on the geohydrologic data collected in this and other studies at Area T.

1. Tuff Layers with Clay. The first high concentrations of radionuclides and water encountered in the tuff beneath the gravel-cobble layer in absorption bed 1 were found at sampling depths of 4 to $5.5 \mathrm{~m}$ (Figs. 3-5), where a highly weathered, light orangegray tuff layer with a high clay content was found. This layer, previously described as Bed B (Rogers 1977), would be less permeable than the rest of the surrounding tuff and probably resulted from the severe chemical and hydrologic tuff-weathering processes brought about by the acidic liquid wastes added to this absorption bed.

2. Contact Zones. The next major increase in tuff water content and radionuclide concentrations occurred at a sampling depth of about 8 to $9 \mathrm{~m}$ in absorption bed 1 (Figs. 3-5). At this depth we encountered a change in tuff units from the upper-lying, light brownish-gray, moderately welded tuff to the lower-lying, light gray, moderately welded tuff. This contact zone was identified on the basis of color changes and the change in the total amount of force required to drive the split spoon sampler into the tuff. For example, in hole 1 of absorption bed 1, the upper tuff unit required 102 to 157 blows of a lili-kg hammer to extract a $61-\mathrm{cm}$ core sample, whereas the unit under the contact zone only required 23 to 60 blows to collect a similar sample. Contact zones such as this exhibit increased welding, decreased porosity (Abeele et al. 1981), and, thus, decreased conductivity relative to the adjacent tuff units. Using the neutron probe data collected in the 1961 study (Christenson and Thomas 1962), we estimated the saturated hydraulic conductivity, $\mathrm{K}$, of this layer to be $0.0025 \mathrm{~cm} / \mathrm{h}$, which corresponds to both a $10-$ fold lower water transmission rate and a 10 -fold longer contact time between soluble radionuclides and tuff than for that of the overylying unit of tuff (Nyhan 1979).

3. Fractures in the Tuff. Fractures, originally formed by cooling of the tuff ash flows, commonly divide the tuff into irregular blocks and account for some of the variations in tuff water content shown in Fig. 5. Although a few fractures occurring from 3 to $12 \mathrm{~m}$ at this site could have received saturated flow of liquids directly from the large amounts of effluents discharged to absorption bed 1 (Abrahams 1963), fractures usually act as barriers for unsaturated liquid flow (Abeele et al. 1981). For example, a fracture was found in hole 1 of absorption bed 2 at a depth of 10.06 to $10.21 \mathrm{~m}$. The fracture fillings had a water content of $12.5 \%$, compared with a value of $16.15 \%$ in the adjacent tuff sample collected at the 9.91- to 10.06-m-depth increment. The water contents of tuff samples collected at the 23- and 24-m depths in hole 1 of absorption bed 1 were also elevated, probably indicating the presence of fractures close to and below the hole but not detected in the hole.

Because previous studies at Area $T$ emphasized the role of fractures in promoting vertical radionuclide migration (Abrahams 1963, Christenson and Thomas 1962), we collected samples of fracture fillings and analyzed them for radionuclide concentrations. No significant differences were found in radionuclide concentrations between fracture fillings and adjacent tuff samples in eight out of ten cases, where fractures were encountered at sampling depths ranging from 2 to $18 \mathrm{~m}$ in both absorption beds. Both 
SOIL WATER CONTENT (\%)
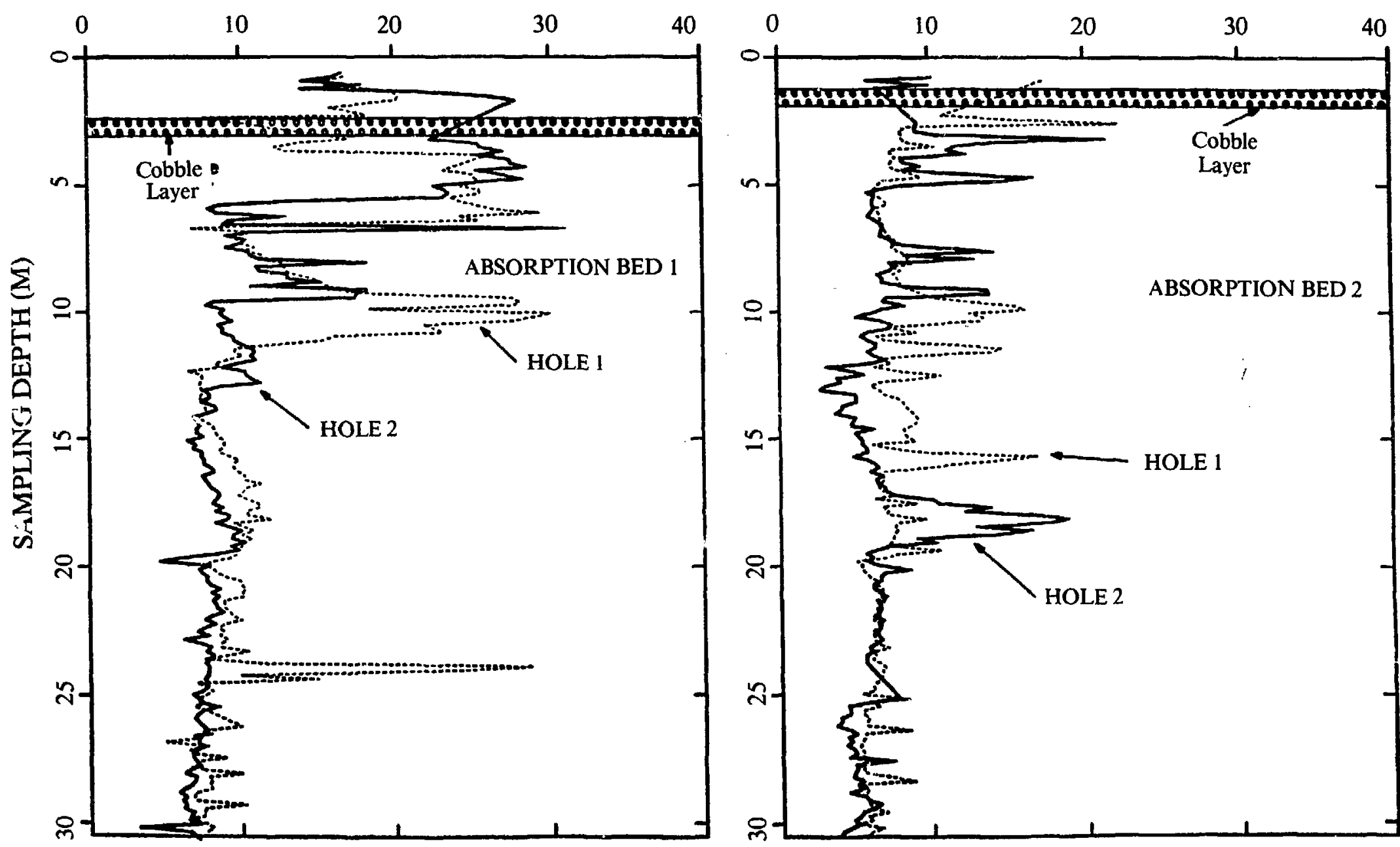

Fig. 5. Gravimetric soil water content as a function of sampling depth for absorption beds 1 and 2 in 1978 . 
cases involving higher radionuclide concentrations in the fine-textured fracture fillings than in the tuff adjacent to the fractures were found in the upper unit of tuff, i.e., at sampling depths of $6.6 \mathrm{~m}$ in absorption bed 1 (2-fold difference in radionuclide concentrations) and $3.5 \mathrm{~m}$ in absorption bed 2 (3-fold difference in radionuclide concentrations). Thus, these results tend to support the idea that fractures in the tuff generally act as barriers to unsaturated flow of migrating waste solutions (Abeele et al. 1981); however, fractures may play a role in conveying waste solutions through the tuff near the bottoms of the absorption beds where saturated flow conditions were more commonly found.

4. $\mathrm{pH}$ of the Wastes and Tuff. During the final week of the addition of $10.8 \mathrm{~m}$ of untreated, acidic (usuaily $\mathrm{pH} 3$ to 4) wastes to absorption bed 1 in 1961 , the $\mathrm{pH}$ of water samples extracted from the tuff at sampling depths of 0.9 to $8.5 \mathrm{~m}$ was studied (Christenson and Thomas 1962). The $\mathrm{pH}$ values of these water samples usually ranged from 4 to 5 but returned to $\mathrm{pH} 8$ to 9 after the subsequent addition of $9.7 \mathrm{~m}$ of tap water four weeks later, reflecting a dilution of the acidic wastes initially added to the tuff and the natural buffering capacity of the tuff.

We further evaluated these 1961 results by performing $\mathrm{pH}$ determinations on a few of the tuff samples collected in our 1978 study (Table I). The

\section{TABLE I}

\section{AVERAGE PH OF TUFF SAMPLES COLLECTED BENEATH ABSORPTION BEDS AT AREA T IN 1978}

\begin{tabular}{|c|c|c|}
\hline \multirow{2}{*}{$\begin{array}{c}\text { Sampling Depth } \\
\text { (m) }\end{array}$} & \multicolumn{2}{|c|}{$\begin{array}{l}\text { Average and Standard } \\
\text { Deviation of pH of } \\
\text { Tuff from Absorption } \\
\text { Bed Number }\end{array}$} \\
\hline & 1 & 2 \\
\hline $\begin{array}{l}\text { Immediately below } \\
\text { gravel cobble layer }\end{array}$ & $7.6(0.5)$ & $6.8(0.50)$ \\
\hline $10.06-10.21$ & $7.6(0.78)$ & $7.0(0.25)$ \\
\hline $16.00-16.15$ & $8.7(0.06)$ & $7.3(0.47)$ \\
\hline $19.51-19.66$ & $7.4(0.40)$ & $7.5(0.91)$ \\
\hline $25.60-25.76$ & $7.5(0.01)$ & $7.0(0.11)$ \\
\hline $30.02-30.18$ & $7.5(0.06)$ & $8.0(0.73)$ \\
\hline $30.18-30.33$ & $8.1(0.12)$ & $7.6(0.91)$ \\
\hline
\end{tabular}

${ }^{a}$ Average $\mathrm{pH}$ of one sample collected at each depth from each of two holes. average pH of tuff samples collected in absorption bed 2 ranged from 7.0 to 8.0 below sampling depths of $16 \mathrm{~m}$, which corresponded to sampling depths not receiving detectable levels of plutonium and ${ }^{241} \mathrm{Am}$ wastes (Figs. 3 and 4). Samples collected in sampling locations other than these and beneath both beds, which obviously received large volumes of wastes (Figs. 3 and 4), exhibited no significant differences in $\mathrm{pH}$ (Table I). This observation indicates that the natural buffering capacity of the tuff was still maintaining the pH of this geochemical system in 1978 (and not the acidity of the waste solutions added in the past), just as it did after the additions of water to absorption bed 1 in 1961 .

\section{Inventoriss of Radionuclides and Water Beneath the Absorption Beds}

Inventories of radionuclides found beneath the absorption beds were calculated by multiplying the radionuclide concentration of the sample by the oven-dry weight of each sample. Because radionuclides were not found below $11.28 \mathrm{~m}$ belıeath bed 2 (Figs. 3 and 4), the resulting inventory (for the projected area of the hole) was then summed for all the samples from depths of 0 to $11.28 \mathrm{~m}$ and 11.28 to $27.13 \mathrm{~m}$ below both of the absorption beds (Table II). For absorption bed 2, total piutonium inventories ranged from 33 to $61 \mu \mathrm{Ci}$ and total ${ }^{241} \mathrm{Am}$ inveniories ranged from 16 to $26 \mu \mathrm{Ci}$. For absorption bed 1 , hole 1 contained $212 \mu \mathrm{Ci}$ plutonium and $223 \mu \mathrm{Ci}{ }^{241} \mathrm{Am}$, and $6.9 \mu \mathrm{Ci}$ plutonium and $5.6 \mu \mathrm{Ci}^{241} \mathrm{Am}$ were found in hole 2. Coefficient of variation (standard deviation of mean/mean) estimates of radionuclide inventories were 3- to 4-fold higher for absorption bed 1 than for bed 2 , probably reflecting enhanced variation in liquid waste deposition patterns near the point of entry of the waste solutions into the absorption bed (Fig. 2) as shown previously (Herman 1954, Abrahams 1963, Christensoji and Thomas 1962). Thus, even though the bed 1 samples were collected closer to where the wastes were added to the bed than the bed 2 samples were (Fig. 2), ro significant differences in total radionuclide inventories could be found between these two absorption beds; this observation supports the idea that approximately equivalent amounts of wastes were added to each bed through the distribution box between beds 1 and 2 (Fig. 2).

To better understand the relationship between radionuclides and the major radionuclide redistribution factor, water, we calculated the total inventory of water in the tuff samples from each hole. The total centimeters of water in each sample were calculated 
by multiplying the sample's gravimetric water content (per cent water divided by 100 ' by the bulk density of the sample and the sampling depth $(\mathrm{cm})$. Because the maximum penetration of radionuclides beneath absorption bed 2 was $11.28 \mathrm{~m}$ below the gravel-cobble layer at the bottom of the absorption bed, the inventory of water was calculated for the same depths as for the radionuclide inventories (Table II). The water inventory calculations clearly demonstrate that even 17 years after the 1961 additions of water to absorption bed 1, elevated water contents can be found under this bed. Holes 1 and 2 in absorption bed 1 contained 435 and $380 \mathrm{~cm}$ of water, respectively, whereas holes 1 and 2 in absorption bed 2 only contained 286 and $260 \mathrm{~cm}$ of water, respectively. In addition, total inventories of water and radionuclides werè directly correlated within each absorption bed, indicating enhanced radionuclide migration with elevsted levels of water in the tuff (Table II).

The most important information to be gleaned from Table II, however, is related to the inventories of radionuclides and water found at the 11.28 - to $27.13 \mathrm{~m}$ depths of both holes in absorption bed 1 .
Thus, in hole 1 of absorption bed $1,10.7 \mu \mathrm{Ci}$ plutonium and $6.66 \mu \mathrm{Ci}^{241} \mathrm{Am}$ were translocated to this depth (Table II), representing 5.1 and $3.0 \%$, respectively, of the radionus:ide inventories in this hole. The samples from hole 2 of this absorption bed, which contained very low radionuclide inventories, exhibited only $0.022 \mu \mathrm{Ci}$ plutonium and $2.79 \mu \mathrm{Ci}$ ${ }^{241} \mathrm{Am}$ within the 11.28- to 27.13-m-depth increment (Table II), representing 0.3 and $49 \%$, respectively, of the radionuclide inventories. The relative distribution of the water inventory with depth demonstrated an amazingly consistent pattern for this bed. The top $11.28 \mathrm{~m}$ of the profiles below absorption bed 1 contained $55 \%$ of the inventory of water, with only $45 \%$ of the inventory found at the 11.28- to $27.13-\mathrm{m}$ depth (Table II). Thus, these data also indicate that 17 years after the addition of a large slug of water to absorption bed 1, the tuff located 11.28- to 27.13-m below this bed contained significant radionuclide inventories and a $25 \%$ higher average water inventory than did the tuff at a corresponding depth below absorption bed 2 , which did not receive a large addition of water in 1961.

TABLE II

\section{INVENTORIES OF PLUTONIUM, AMERICIUM, AND WATER BENEATH ABSORPTION BEDS AT AREA T IN 1978}

\begin{tabular}{|c|c|c|c|c|}
\hline \multirow{3}{*}{$\begin{array}{c}\text { Depth Below Bottom } \\
\text { of Absorption Bed } \\
(\mathrm{m})\end{array}$} & \multicolumn{4}{|c|}{ Inventory } \\
\hline & \multicolumn{2}{|c|}{ Absorption Bed 1} & \multicolumn{2}{|c|}{ Absorption Bed 2} \\
\hline & Hole 1 & Hole 2 & Hole 1 & Hole 2 \\
\hline & \multicolumn{4}{|c|}{ Plutonium ( $\mu \mathrm{Ci})$} \\
\hline $0-11.28$ & 201.3 & 6.934 & 61.28 & 33.05 \\
\hline $11.28-27.13$ & 10.71 & 0.022 & 0.00 & 0.00 \\
\hline \multirow[t]{2}{*}{ Total Inventory } & 212.01 & 6.956 & 61.28 & 33.05 \\
\hline & \multicolumn{4}{|c|}{ Americium $(\mu \mathbf{C} \mathbf{i})$} \\
\hline $0-11.28$ & 216.1 & 2.829 & 26.11 & 15.66 \\
\hline $11.28-27.13$ & 6.664 & 2.787 & 0.00 & 0.00 \\
\hline \multirow[t]{2}{*}{ Total Inventory } & 222.764 & 5.616 & 26.11 & 15.66 \\
\hline & \multicolumn{4}{|c|}{ Soil Water (cm) } \\
\hline $0-11.28$ & 241 & 211 & 135 & 120 \\
\hline $11.28-27.13$ & 194 & 169 & $15]$ & 140 \\
\hline Total Inventory & 435 & 380 & 286 & 260 \\
\hline
\end{tabular}


As time proceeds, the ${ }^{241} \mathrm{Am}$ data present is more complex picture than the plutonium information generated in this study. The ${ }^{241} \mathrm{Am}$ found in our samples came not only from the original process waste solutions added to the absorption beds but also from the continuous beta decay of its ${ }^{241} \mathrm{Pu}$ parent in the wastes, which has a half-life of only 13.2 years (Fried et al. 1978); consequently, this second source generates ${ }^{241} \mathrm{Am}$ long after disposal and at a depth dependent on the migration of the precursor. We investigated the influence of the ${ }^{241} \mathrm{Pu}$ on our ${ }^{241} \mathrm{Am}$ data by collecting information on the amounts of ${ }^{241} \mathrm{Pu}$ in the wastes and the radiological characteristics of this isotope. The common weapons-grade plutonium mix found at Los Alamos, which was similar to what the Area $T$ absorption beds received, contains only $0.4 \%{ }^{241} \mathrm{Pu}$ by weight (H-Division Staff 1979). Since most of the plutonium had been added to the absorption beds by 1952 , we estimated that two halflives worth of ${ }^{241} \mathrm{Am}$ had been formed from the ${ }^{24 !} \mathrm{Pu}$ originally added to the beds. Using the radiological data for ${ }^{241} \mathrm{Am}$ (Wick 1967), we then calculated that the amount of ${ }^{241} \mathrm{Am}$ decaying from ${ }^{241} \mathrm{Pu}$ in these wastes after two half-lives should equal $16 \%$ of the plutonium inventory on an activity basis. A comparison of the amounts of ${ }^{241} \mathrm{Am}$ and plutonium actually found in the tuff samples (Table II) shows that 3 to 7 times more ${ }^{2 a}$ Am was found under the beds than could have been generated from ${ }^{241} \mathrm{Pu}$ decay. For example, $16 \%$ of the $212 \mu \mathrm{Ci}$ of plutonium found in hole 1 of absorption bed 1 would have resulted in $33.92 \mu \mathrm{Ci}^{241} \mathrm{Am}$ generated from ${ }^{241} \mathrm{Pu}$, yet almost 7 times this amount of ${ }^{241} \mathrm{Am}$ was found in samples collected from this hole. Thus, while the ${ }^{241} \mathrm{Am}$ generated from ${ }^{241} \mathrm{Pu}$ may have increased the complexity of making temporal comparisons in the vertical distributions of radionuclides beneath the absorption beds, this effect was minimized by the fact that laiger amounts of ${ }^{241} \mathrm{Am}$ evidently existed in the original waste solutions than were eventually formed by ${ }^{24 !} \mathrm{Pu}$ decay.

\section{DISCUSSION OF RADIONUCLIDE MI- GRATION WITH TIME AT AREA T}

Because the long-term migration of radionuclides in the porous materials of a burial site is an important issue, we examined the question of what happened to the distribution of radionuclides with time at Area T. In the succeeding subsections we first demonstrate the results of previous studies of the vertical distribution of radionuclides at Area $T$ and compare them with the results of our 1978 study. We will then use the hydrologic characteristics of the tuff at Area T and at Mesita del Buey as a time marker to more precisely estimate what happened with time to the vertical distributions of radionuclides at Area $T$.

\section{A. Vertical Radionuclide Distributions at Various Sampling Dates}

Estimates of the distribution of plutonium beneath absorption bed 1 were made for the 1953 (Herman 1954) and 1960 (Christenson and Thomas 1962) studies and compared with our 1978 results (Fig. 6). The results of the 1953 study used here were for the DPW-4 hole, which was closest to our hole 1 in absorption bed 1 . In 1953, peak concentrations of 16300 and $20500 \mathrm{pCi} \mathrm{Pu/g}$ were found above the tuff in the sand and gravel bed bottom, with $5.4 \mathrm{pCi} / \mathrm{g}$ found at the maximum sampling depth of $6.1 \mathrm{~m}$. The general vertical distribution pattern of plutonium with depth at this time was similar to the 1978 data.

The 1960 data plotted in Fig. 6 represent the average estimated plutonium concentrations found in from 4 to 10 core samples per depth collected directly under absorption bed 1 when horizontal hoies were drilled into the northeastern corner of the absorption bed. The original gross alpha radiation determinations $(\mathrm{cpm} / \mathrm{g})$ were intended to represent plutonium concentrations ( $(\mathrm{pCi} / \mathrm{g})$, which we estimated, but were also known to reflect alpha radiations by ${ }^{241} \mathrm{Am}$. However, these 1960 data exhibited decreases in radionuclide concentrations from 3380 $\mathrm{pCi} / \mathrm{g}$ immediately beneath the cobble-gravel layer to about $17 \mathrm{pCi} / \mathrm{g}$ at the $6.71 \mathrm{~m}$ sampling depth, only to increase to $453 \mathrm{pCi} / \mathrm{g}$ at $7.3 \mathrm{~m}$ (Fig. 6). The 1978 data showed very similar trends, such as at the 7 to $8 \mathrm{~m}$ depth where the contact zone was encountered.

Thus, as time proceeded, it appears that the peak plutenium concentration gradually moved downward below bed 1 (Fig. 6) and was unaffected by the tuff zone with high clay concentrations and the contact zone. However, both the 1953 and 1960 studies only sampled the upper $10 \mathrm{~m}$ of the absorption bed profile, so that no direct comparisons can be made with the data collected below this depth in our 1978 study.

\section{B. Use of Site Hydrology as a Time Marker}

Because the distribution of radionuclides $10 \mathrm{~m}$ beneath absorption bed 1 has only been determined in our 1978 study, we had to estimate how fast 


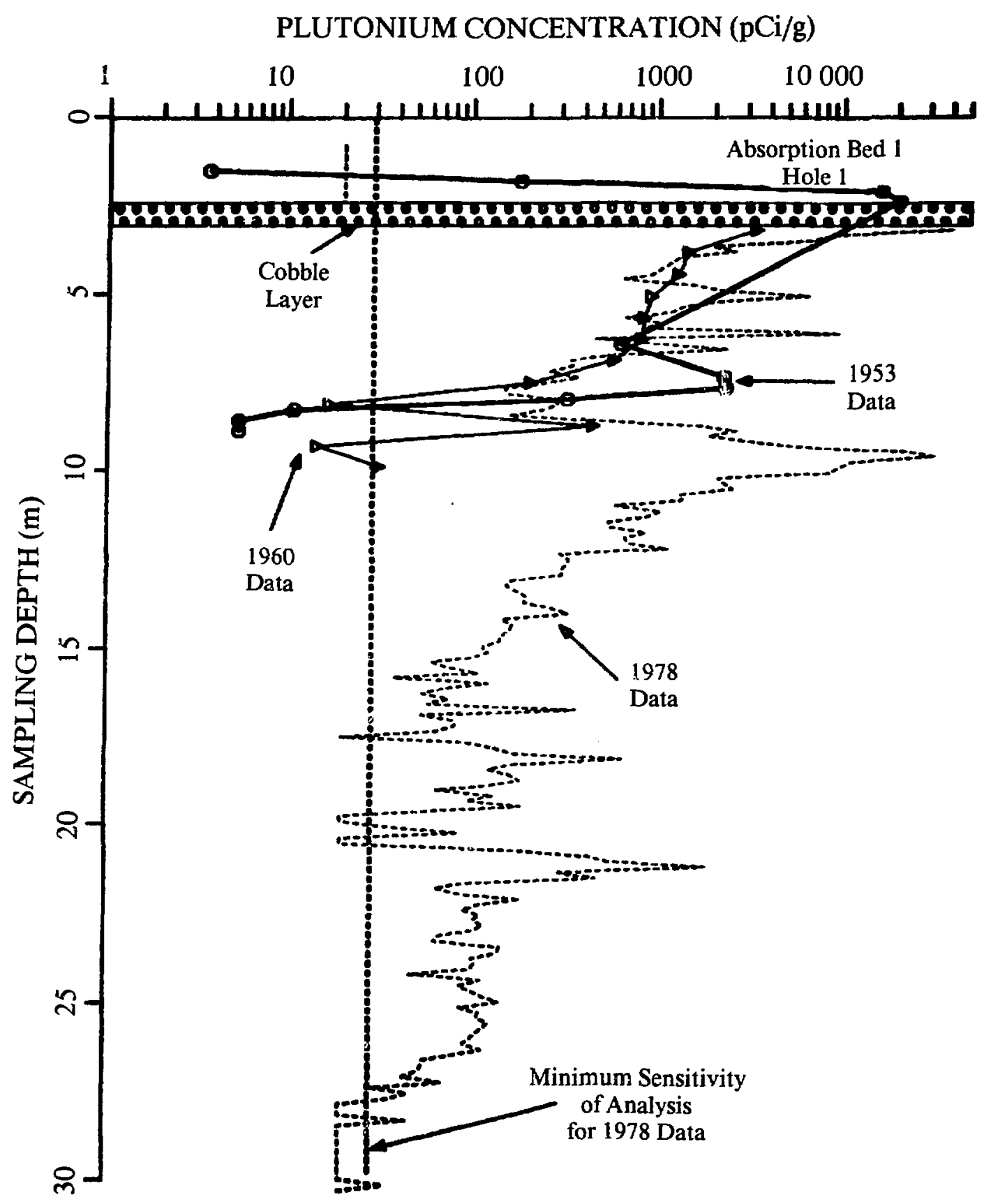

Fig. 6. Concentration of plutonium as a function of sampling depth in absorption bed 1 found in 1953 (Herman 1954), 1960 (Christenson and Thomas 1962), and in our study in 1978. 
radionuclide migration occurred beneath this bed from estimates of the movement of water, which is the driving force for radionuclide migration.

Besides our 1978 study, the only oth $/$ r comprehensive study of water distributions in the tuff below the absorption beds at Area $\mathrm{T}$ was done in 1961 (Abrahams 1963, Christenson and Thomas 1962). Hole 2 of this 1961 study was found to re adjacent to our hole 1 in aissorption bed 1 ar.d consisted of the location where a neutron moisture gauge access tube extended almost $30 \mathrm{~m}$ below the bed. We estimated water inventories in the tuff beneath bed 1 for tw: sampling dates in 1961 (using the methods described previously) and compared this neutron moisture gauge data with the results of our 1978 study (Table III). In late June 1961 before the large addition of water to this absorption bed, the total water inventory beneath the absorption bed was $432 \mathrm{~cm}$. In late A.ugust 1961 , immediately after the addition of water to the absorption bed, the inventory of water in the tuff increased to $751 \mathrm{~cm}$. Our data, which was collected in 1978 for hole 1 , showed a total water inventory of $435 \mathrm{~cm}$. : value very similar to the estimated inventory obs 'ived in June 1961 before the water was added to ihis absorption bed. Thus, $316 \mathrm{~cm}$ of water drained out of this tuff profile sometime between 1961 and 1978 , resulting in a $42 \%$ decrease in water inventory.

Because no additional data were collected after August 1961 in Christenson and Thomas's 1961 study to follow the drainage of water out of the tuff, we decided to estimate the drainage rate from an infiltration/drainage experiment performed at Mesita del Buey (Abrahams 1963), a site with similar geohydrologic characteristics. In this study, water was continuously added to a 0.91 - by 0.91 - by $0.91-\mathrm{m}$ pit for 230 days at a rate of about $0.2 \mathrm{~m}$ per day, similar to the water addition rate in the Area $T$ study (Christenson and Thomas 1962). Neutron moisture gauge readings were collected to a depth of $11 \mathrm{~m}$ before and immediately after water additions to the pit, as well as affer 286 days of drainage of the tuff (Table IV). The results show that $72 \mathrm{~cm}$ of water drained out of this tuff profile after only 286 days, with the result that the inventory of water in the tuff profile was back to what the original water inventory had been in the Mesita del Buey pit.

The results of the Mesita del Buey infiltration/drainage study demonstrate that it only takes about 286 days of drainage for the inventory of water in the tuff profile to be reduced to approximately its original pre-addition value. This implies that most of the water and, thus, radionuclides probably migrated between 1961 and 1962 at Area T and not between 1961 and 1978. However, after 1962, the water and radionuclides probably did continue to nigrate, but very slowly, since reduced levels of soil water result in unsaturated conductivities that are many orders of magnitude less than they were in 1961 when the water was originally added to this Area $\mathrm{T}$ absorption bed (Abcele et al. 1981).

TABLE III

INVENTORY OF WATER (CM) IN THE TUFF BELOW ABSORPTION BED 1 AT THREE SAMPLING TIMES

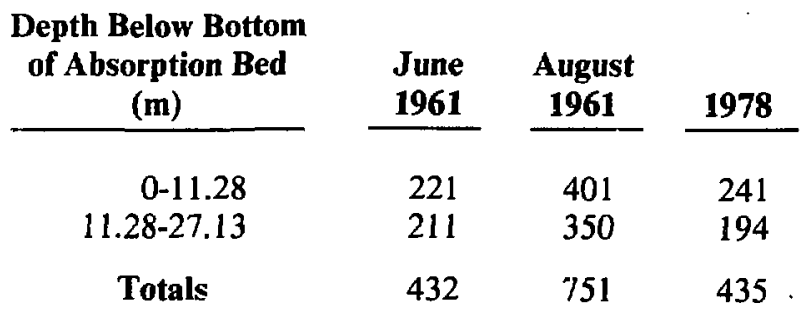

Note: Inventory estimates from the neutron moisture gauge data of Christenson and Thomas (1962). The moisture gauge data were collected in June 1961 (before the addition of water to the absorption bed) and in late August 1961 (immediately after the last addition of water to tine absorption bed). 
TABLE IV

\section{INVENTORY OF WATER IN TUFF AT THREE SAMPLING TIMES IN THE MESITA DEL BUEY STUDY}

\section{Sampling Date}

April 20, 1960

December 6, 1960

October 12, 1961

Note: These data represent estimates from the neutron moisture gauge data of Christenson and Thomas (1962). The moisture gauge data were collected in June 1961 (before the addition of water to the absorption bed) and in late August 1961 (immediately after the last addition of water to the absorption bed).

\section{NUCLEAR WASTE MANAGEMENT IM- PLICATIONS}

In view of the results of the extensive laboratory studies of radionuclide migration in Bandelier Tuff, it is apparent that one cannot fully exirapolate from laboratory studies, using baichi equilibrium and intact core samples, to conditions that prevail in the field. Early laboratory studies demonstrated that essentially all of the plutonium was retained within the top few miliimeters of tuff cores (Christenson et al. 1958), whereas our field study has shown plutonium penetrating to maximum sampling depths of over 30 $\mathrm{m}$ ! Once the plutonium and ${ }^{241} \mathrm{Am}$ are initially $\mathrm{ab}-$ sorbed in tuff, laboratory results using intact tuff cores demonstrated that $1 \%$ of the plutonium inventory and only $0.022 \%$ of the ${ }^{241} \mathrm{Am}$ inventory could be mobilized after the addition of 1000 column volumes of water (Fried et al. 1976). Our field study results demonstrate that from 0.3 to $5.1 \%$ of the plutonium and from 3.0 to $49.6 \%$ of the ${ }^{241} \mathrm{Am}$ initially absorbed can be mobilized with the addition of less than 1 column volume of water $[316 \mathrm{~cm}$ of water drained out of the tuff profile (Table III), whereas one column volume of water, covering the area of one absorption bed to a sampling depth of $30.5 \mathrm{~m}$, would contain $1067 \mathrm{~cm}$ of water].
The laboratory studies at Argonne National Laboratory demonstrated a distinct peak concentration of mobile plutonium migrating 10 times faster than the bulk of the plutonium in tuff; however, our 1978 field data did not show an analogous peak concentration band for either plutonium or ${ }^{241} \mathrm{Am}$. Although the full reason for this difference is unclear at present, part of the explanation probably involves the occurrence of heterogeneous geologic layers in the field, which contain drastically different hydrologic charactistics that change the kinetics of the flow of water and radionuclides through the tuff.

A previous field study (Christenson and Thomas 1962) attributed the major portion of the vertical migration of transuranics in tuff to flow of liquid wastes through fractures in the tuff. Our results indicate that radionuclide concentrations in the tuff are generally correlated to the water content of the tuff and not just in sampling locations involving fractures. The ${ }^{241} \mathrm{Am}$ data, for example, suggest a continuous flow of water and ${ }^{2 ! !}$ Am through almost $30 \mathrm{~m}$ of intact tuff and around fractures in the tuff (Fig. 4), with ${ }^{241} \mathrm{Am}$ migrating farther than platonium in this manner.

By gaining an appreciation for the amounts of long-iived radionuclides migrating in soils and geologic materials and the geohydrology of a site, we car, factor this information into our environmental monitoring and disposal practices; thus, the probability that the public will be exposed to significant adverse health risks will be reduced. Data generated in this study are aiso currently being used to design fiela sampling programs to evaluate radionuclide migration at Area $\mathrm{T}$ in much more detail and to evaluate hydrologic models dealing with unsaturated water flow in Bandelier Tuff. Information similar to that gathered in this study at Area $\mathrm{T}$ is needed for many sites with varying environmental conditions before the long-term behavior of long-lived radionuclides can be more clearly undersiood.

\section{ACKNOWLEDGMENTS}

We thank J. Umbarger and J. Crowell of the Laboratory's Group IT-1 for their efforts in the early instrumentation planning and development phases for this project. Special thanks are aiso extended to $M$. Lewis for again reading our illegible handwriting and for editing, typesetting, and layout of this now legible manuscript. 


\section{REFERENCES}

Abcele, W. V., M. L. Wheeler, and B. W. Burton, "Geohydrology of Bandelier Tuff," Los Alamos National Laboratory report LA-8962-MS (1981).

Abrahams, J. H., Jr., "Radioactive Waste Disposal at Los Alamos, New Mexico," prepared in cooperation with the US Atomic Energy Commission and the Los Alamos Scientific Laboratory, unpublished manuscript in files of US Geological Survey, Albuquerque, New Mexico (1962).

Abrahams, J. H., Jr., "Physical Properties of and Movement of Water in the Bandelier Tuff, Los Alamos and Santa Fe Counties, New Mexico," prepared in cooperation with the US Atomic Energy Commission and the Los Alamos Scientific Laboratory, unpublished manuscript in files of US Geological Survey, Albuquerque, New Mexico (1963).

Christenson, C. W., E. B. Fowler, G. L. Johnson, E. H. Rex, and F. A. Virgil, "Soil Adsorption of Radioactive Wastes at Los Alamos," Sewage and Industrial Wastes 30, 1478-1489 (1958).

Christenson, C. W., and R. G. Thomas, "Movement of Plutonium Through Los Alamos Tuff," in "Second Ground Disposal of Radioactive Wastes Conference," Technical Services, US Department of Commerce report TID-7628 (1962), pp. 249-282.

Fried, S. M., A. M. Friedman, J. J. Hines, and L. A. Quarterman, "Annual Report on DWMT Project AN01 15A, FY 1975," Argonne National Laboratory report ANL-75-64 (1975).

Fried, S. M., A. M. Friedman, J. J. Hines, R. W. Atcher, L. A. Quarterman, and A. Volesky, “Annual Report for FY 1976 on Project AN0115A: The Migration of Plutonium and Americium in the Lithosphere," Argonne National Laboratory report ANL-76-127 (1976).

Fried, A. M., A. M. Friedman, J. J. Hines, G. Schmitz, and $M$. Wheeler, "Distribution of Plutonium and Americium at a Former Los Alamos Waste Disposal Site," in "Transuranics in Natural Environments," M. G. White and P. B. Dunaway (Eds.), Nevada Applied Ecology Group report NVO-178 (1977), pp. 115-126.
Fried, S. S., A. M. Friedman, D. Cohen, J. J. Hines, and R. G. Sirickert, "The Migration of Long-Lived Radioactive Processing Wastes in Selected Rocks," Argonne National Laboratory report ANL-78-46 (i978).

H-Division Staff, "Transuranic Solid Waste Management Research Programs Quarterly Report, OctoberDecember 1973," Los Alarnos Scientific Laboratory report LA-5614-PR (1974).

H-Division Staff, "Los Alamos Scientific Laboratory Health, Safety, and Environment Manual," Los Alamos Scientific Laboratory manual (1979).

Herman, E. G., "Retention of Plutonium in Waste Seepage Beds at Los Alamos," unpublished manuscript in files of US Geological Survey, Santa Fe, New Mexico (1954).

Kingsley, W. H., A. Foxx, and J. F. Tribby, "Survey of Lr: Alamos and Pueblo Canyons for Radioactive Contamination and Radioassay Tests Run on SewerWater Samples, and Water and Soil Samples Taken from Los Alamos and Pueblo Canyons," Los Alamos Scientific Laboratory report LAMS-516 (1947).

Nyhan, J. W., "Radioactive Waste Burial in Tufi at Los Alamos," Los Alamos Scientific Laboratory report LA-7921-PR (1979).

Nyhan, J. W., B. J. Drennon, and J. M. Crowell, "Evaluation of an Automated Assay System to Measure Soil Radionuclides by L X-ray and Gammaray Spectrometry," Soil Science Society of America Journal 47, 486-490 (1983).

Purtymun, W. D., Letter to W. E. Hale, District Chief of USGS to W. Kennedy, Group Leader, H-6, February 20, 1967 in M. A. Rogers, "History and Environmental Setting of LASL Near-Surface Land Disposal Facilities for Radioactive Wastes (Areas A, B, C, D, E, F, G, and T)," Los Alamos Scientific Laboratory report LA-6848-MS, Vol. I (1977), pp. T1-40.

Rogers, M. A., "History and Environmental Setting of LASL Near-Surface Land Disposal Facilities for Radioactive Wastes (Areas A, B, C, D, E, F, G, and T)," Los Alanos Scientific Laboratory report LA-6848-MS, Vol. 1 (1977). 
Trujillo, G., J. W. Nyhan, and J. M. Crowell, “Automated Transuranic Assay System for Soils," Los Alamos Scientific Laboratory report LA-8376LLWM (1980).
Wick, O. J. (Ed.), Plutonium Handbook, Vol. II (Gordon and Breach, Science Publishers, New York, 1967). 


\section{APPENDIX A \\ DRILLING LOGS FOR FOUR HOLES DRILLED \\ IN 1978 AT AREA T}


TABLE A-I

\section{SAMPLE LOG FOR HOLE 1 IN ABSORPTION BED 1 AT AREA T}

[4.88 $\mathrm{m}$ from east end of bed 1 and in the center of the bed]

\begin{tabular}{|c|c|c|c|c|}
\hline \multirow{2}{*}{$\begin{array}{l}\text { Sample } \\
\text { Depth } \\
\text { (ft) }\end{array}$} & \multirow[b]{2}{*}{$\begin{array}{l}\text { Description and Comments } \\
\text { on Sample Collected }\end{array}$} & \multicolumn{2}{|c|}{ Blows with } & \multirow[b]{2}{*}{$\begin{array}{c}\text { Sample } \\
\text { Date } \\
\end{array}$} \\
\hline & & $\begin{array}{c}180 \mathrm{lb} \\
\text { Hammer }\end{array}$ & $\begin{array}{c}400 \mathrm{lb} \\
\text { Hammer }\end{array}$ & \\
\hline $0-2.5$ & No sample collected & - & - & $4 / 27 / 78$ \\
\hline $2.5-4.0$ & $\begin{array}{l}2.5-3.0 \mathrm{ft} \text { : grayish-brown tuff backfill } \\
3.0-4.0 \mathrm{ft} \text { : brown soil with high clay content }\end{array}$ & 55 & - & $4 / 27 / 78$ \\
\hline $4.0-4.5$ & No sample collected & - & - & $4 / 27 / 78$ \\
\hline $4.5-6.0$ & $\begin{array}{l}4.5-5.5 \mathrm{ft} \text { : brown soil with clay } \\
\text { mixed with gray tuff } \\
5.5-6.0 \mathrm{ft} \text { : brown soil with clay }\end{array}$ & - & - & $4 / 27 / 78$ \\
\hline $6.0-8.0$ & $\begin{array}{l}6.0-6.75 \mathrm{ft} \text { : void space } \\
6.75-7.7 \mathrm{ft} \text { : brown soil with high water } \\
\text { content and low (background) alpha activity } \\
7.7-8.0 \mathrm{ft} \text { : brown soil with river gravel } \\
\text { with iron stains and black coverings }\end{array}$ & - & - & $4 / 27 / 78$ \\
\hline $8.0-10.5$ & $\begin{array}{l}\text { Gravel-cobble iayer with } \\
\text { background alpha count }\end{array}$ & - & - & $4 / 28 / 78$ \\
\hline $10.5-12.5$ & $\begin{array}{l}\text { Grayish-brown tuff } \\
10.5-11.5 \mathrm{ft} \text { : dark grayish-brown tuff, } \\
6000 \mathrm{cpm} \text { alpha } \\
11.5-12.5 \mathrm{ft} \text { : light gray tuff, } \\
1500 \mathrm{cpm} \text { alpha }\end{array}$ & 440 & - & $5 / 4 / 78$ \\
\hline $12.5-14.5$ & $\begin{array}{l}12.5-13.5 \mathrm{ft} \text { : muddy from snow melt, } \\
\text { some of which went into hole; } \\
\text { dark gray tuff } \\
13.5-12.5 \mathrm{ft} \text { : gray tuff }\end{array}$ & - & 140 & $5 / 5 / 78$ \\
\hline $14.5-16.5$ & $\begin{array}{l}\text { Light gray tuff (hole covered } \\
\text { more thoroughly than previously } \\
\text { due to snow and rain } 5 / 5-5 / 7 \text { ) }\end{array}$ & - & 102 & $5 / 8 / 78$ \\
\hline $16.5-18.5$ & $\begin{array}{l}16.5-17.5 \mathrm{ft} \text { : light brown tuff zone } \\
\text { in light gray tuff } \\
17.5-18.5 \mathrm{ft} \text { : light gray tuff }\end{array}$ & - & 157 & $5 / 8 / 78$ \\
\hline $18.5-20.5$ & $\begin{array}{l}\text { Light gray-brown tuff with a few } \\
\text { orange-brown stains in matrix }\end{array}$ & - & - & $5 / 8 / 78$ \\
\hline $20.5-22.5$ & $\begin{array}{l}20.5-21.5 \mathrm{ft} \text { : moist due to water } \\
\text { in hole, dark gray tuff } \\
21.5-22.0 \mathrm{ft} \text { : fracture filling } \\
22.0-22.5 \mathrm{ft} \text { : light gray tuff }\end{array}$ & - & - & $5 / 8 / 78$ \\
\hline $22.5-24.5$ & Light gray-brown tuff, no fractures & - & 130 & $5 / 8 / 78$ \\
\hline $24.5-26.5$ & Light gray tuff, no fraciures & - & 75 & $5 / 9 / 78$ \\
\hline $26.5-28.5$ & Light gray tuff, no fractures & - & 40 & $5 / 9 / 78$ \\
\hline $28.5-30.5$ & Dark gray tuff, no fractures & - & 26 & $5 / 9 / 78$ \\
\hline
\end{tabular}


TABLE A-I (cont)

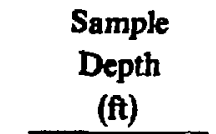

$\overline{30.5-32.5}$

$32.5-34.5$

$34.5-36.5$

$36.5-38.5$
$38.5-40.5$
$40.5-42.5$

$42.5-44.5$

$44.5-46.5$

$46.5-48.5$

$48.5-50.5$

$50.5-52.5$

$52.5-54.5$

$54.5-56.5$

$56.5-58.5$

$58.5-60.5$

$60.5-62.5$

$62.5-64.5$

$64.5-66.5$

$66.5-68.5$

$68.5-70.5$

$70.5-72.5$

$72.5-74.5$

$74.5-76.5$

$76.5-78.5$

$78.5-80.5$

$80.5-82.5$

$82.5-84.5$
Description and Comments

on Sampla Collected

30.5-31 ft: dark gray tuff

31.0- $32.5 \mathrm{ft}$ : brown-gray tuff, but not a fracture

32.5-33.5 ft: light gray tuff

33.5-34.5 ft: brown weathered tuff

intrusion into gray tuff

$34.5-35.5 \mathrm{ft}$ : same as $\mathbf{3 3 . 5 - 3 4 . 5}$

ft segment

35.5-36.5 ft: light gray tuff

Light gray tuff

Light gray tuff

40.5-40.8 $\mathrm{ft}$ fracture with

brown filling intruding gray tuff

40.8-42.5 ft: light gray tuff

Light gray tuff

Light gray tuff

Light gray tuff

Light gray tuff

$50.5-50.8 \mathrm{ft}$ : dark gray

50.8-52.5 ft: light gray

Light gray tuff

Light gray tuff

Light gray tuff

58.5-59.5 ft: fracture with

light brown colored filling

$59.5-60.5 \mathrm{ft}$ : light gray tuff

$60.5-61.4 \mathrm{ft}$ : light gray tuff

61.4-61.6 ft: rock

$61.6-62.5 \mathrm{ft}$ : light gray tuff

Gray tuff

Gray tuff

Gray tuff with some

yellow iron stains

Dark orange, rusty-colored tuff

matrix with 1-in. moist zone at $68.5 \mathrm{ft}$

Light gray tuff

Light gray tuff

Light gray tuff

Light gray tuff

Light gray tuff

Light gray tuff

82.5 -83.5 ft: gray tuff with iron stains

83.5-84.5 ft: gray tuff
Blows with

\begin{tabular}{|c|c|c|}
\hline $\begin{array}{c}180 \mathrm{lb} \\
\text { Hamimer }\end{array}$ & $\begin{array}{c}400 \mathrm{lb} \\
\text { Hammer }\end{array}$ & $\begin{array}{c}\text { Sample } \\
\text { Date }\end{array}$ \\
\hline - & 26 & $5 / 9 / 78$ \\
\hline - & - & $5 / 10 / 78$ \\
\hline- & - & $5 / 11 / 78$ \\
\hline - & $5 \hat{3}$ & $5 / 11 / 78$ \\
\hline - & 51 & $5 / 11 / 78$ \\
\hline - & 51 & $5 / 11 / 78$ \\
\hline
\end{tabular}

$\begin{array}{lll}- & 54 & 5 / 11 / 78\end{array}$

$\begin{array}{lll}- & 50 \quad 5 / 11 / 78\end{array}$

$\begin{array}{lll}- & 39 & 5 / 17 / 78\end{array}$

$\begin{array}{lll}- & 53 \quad 5 / 17 / 78\end{array}$

$\begin{array}{lll}- & 60 \quad 5 / 17 / 78\end{array}$

$\begin{array}{lll}- & 55 \quad 5 / 17 / 78\end{array}$

- $5585 / 17 / 78$

$\begin{array}{lll}- & 54 & 5 / 17 / 78\end{array}$

$\begin{array}{lll}- & 51 \quad 5 / 17 / 78\end{array}$

$\begin{array}{lll}- & 48 \quad 5 / 17 / 78\end{array}$

$\begin{array}{lll}- & 40 \quad 5 / 17 / 78\end{array}$

$\begin{array}{lll}- & 39 & 5 / 17 / 78\end{array}$

$\begin{array}{lll} & \\ - & 35 & 5\end{array}$

$\begin{array}{lll}- & 31 \quad \$ / 18 / 78\end{array}$

$-\quad 28 \quad 5 / 18 / 78$
$-\quad 26$

- $\quad 26 \quad 5 / 18 / 78$

- $\quad 25 \quad 5 / 18 / 78$

- $\quad 23 \quad 5 / 18 / 78$

$\begin{array}{lll}- & 25 & 5 / 18 / 78\end{array}$

- $\quad 25 \quad 6 / 7 / 78$

- $246 / 7 / 78$ 
TABLE A-I (cont)

\begin{tabular}{c} 
Sample \\
Depth \\
(ft) \\
\hline
\end{tabular}

$$
84.5-86
$$

$86.0-88.0$

$88.0-90.0$

$90.0-92.0$

$92.0-94.0$

$94.0-96.0$

$96.0-98.0$

$98.0-100.0$

\section{Description and Comments}

on Sample Collected
Blows with

\begin{tabular}{ccc}
\hline $180 \mathrm{lb}$ & $400 \mathrm{lb}$ & $\begin{array}{c}\text { Sample } \\
\text { Date }\end{array}$ \\
\hline
\end{tabular}

Auger advanced without taking sample, sample lost

Light gray tuff

Light gray tuff

Light gray tuff with

somè iron stains

Light gray tuff with

some iron stains

Light gray tuff with

$\begin{array}{ll}- & 28 \\ - & 25\end{array}$

\begin{tabular}{l}
$-\quad 28$ \\
\hline
\end{tabular}

a

a

a

some iron stains

- $34 \quad$ a

$\begin{array}{lll}- & 33\end{array}$

Light gray tuff with

48

a

some iron stains

Light gray tuff with

67

a

${ }^{a}$ Exact sampling date in June 1978 unknown. 
TABLE A-II

SAMPLE LOG FOR HOLE 2 IN ABSORPTION BED I AT AREA T

[ $5.49 \mathrm{~m}$ from east end of bed 1 and in ceiter of bed]

\begin{tabular}{|c|c|c|c|}
\hline $\begin{array}{l}\text { Sample } \\
\text { Depth } \\
\text { (ft) }\end{array}$ & $\begin{array}{c}\text { Description and Comments } \\
\text { on Sample Collected }\end{array}$ & $\begin{array}{c}\text { Blows With } \\
400 \text { lb Hammer }\end{array}$ & $\begin{array}{c}\text { Sampling } \\
\text { Date }\end{array}$ \\
\hline \multirow[t]{2}{*}{$2.0-4.0$} & $\begin{array}{l}2.0-2.5 \mathrm{ft} \text { : gray tuff backfill and } \\
\text { brown soil with high clay } \\
\text { concentration mixture }\end{array}$ & 99 & $6 / 15 / 78$ \\
\hline & $2.5-4.0 \mathrm{ft}:$ gray tuff backfill & 9 & \\
\hline $4.0-6.0$ & $\begin{array}{l}4.0-4.5 \mathrm{ft}: \text { gray tuff backfill } \\
4.5-5.0 \mathrm{ft} \text { : gray tuff backfill } \\
\text { and brown soil with high } \\
\text { clay concentration mixture } \\
5.0-6.0 \mathrm{ft}: \text { gray tuff backfill }\end{array}$ & - & $6 / 15 / 78$ \\
\hline $6.0-10.5$ & $\begin{array}{l}\text { Gravel-cobble layer, no samples } \\
\text { collected, no fractures }\end{array}$ & - & $\begin{array}{l}6 / 15 / 78 \\
6 / 16 / 78\end{array}$ \\
\hline $10.5-12.5$ & $\begin{array}{l}\text { Wet sample of brown weathered } \\
\text { tuff with high clay concentration, } \\
\text { no fractures }\end{array}$ & 91 & $6 / 20 / 78$ \\
\hline $12.5-14.5$ & $\begin{array}{l}\text { Wet sample of brown weathered } \\
\text { tuff with high clay concentration, } \\
\text { no fractures }\end{array}$ & 55 & $6 / 20 / 78$ \\
\hline $14.5-16.5$ & $\begin{array}{l}\text { 14.5-16.4 ft: Wet sample of } \\
\text { brown weathered tuff with } \\
\text { high clay concentration, no fractures } \\
16.4-16.5 \mathrm{ft} \text { : brown weathered tuff }\end{array}$ & 75 & $6 / 20 / 78$ \\
\hline $16.5-18.5$ & $\begin{array}{l}\text { Wet gray tuff with no brown coloration; } \\
2-200 \mathrm{~m} \ell \text { saturated mud samples collected }\end{array}$ & 125 & $6 / 20 / 78$ \\
\hline $18.5-20.5$ & Slightly moist gray tuff, no fractures & 180 & $6 / 20 / 78$ \\
\hline $20.5-22.5$ & Slightly moist gray tuff, no fractures & 150 & $6 / 20 / 78$ \\
\hline $22.5-24.5$ & Slightly moist gray tuff, no fractures & 162 & $6 / 20 / 78$ \\
\hline $24.5-26.5$ & Slightly moist gray tuff, no fractures & 140 & $6 / 20 / 78$ \\
\hline $26.5-28.5$ & $\begin{array}{l}\text { Slightly moist gray tuff, no fractures, } \\
\text { appears to be unit change }\end{array}$ & 190 & $6 / 20 / 78$ \\
\hline $28.5-30.5$ & Slightly moist gray tuff, no fractures & 79 & $6 / 20 / 78$ \\
\hline $30.5-32.5$ & $\begin{array}{l}\text { Slightly moist gray tuff, no fractures, } \\
700 \mathrm{cpm} \text { gross alpha }\end{array}$ & 59 & $6 / 20 / 78$ \\
\hline $32.5-34.5$ & Slightly moist gray tuff, no fractures & 49 & $6 / 20 / 78$ \\
\hline $34.5-36.5$ & $\begin{array}{l}\text { Slightly moist gray tuff, no fractures, } \\
400 \mathrm{cpm} \text { gross alpha }\end{array}$ & 60 & $6 / 21 / 78$ \\
\hline $36.5-38.5$ & Slightly moist gray tuff, no fractures & 65 & $6 / 21 / 78$ \\
\hline $38.5-40.5$ & Slightly moist gray tuff, no fractures & 60 & $6 / 22 / 78$ \\
\hline $40.5-42.5$ & Slightly moist gray tuff, no fractures & 55 & $6 / 22 / 78$ \\
\hline $42.5-44.5$ & $42.5-42.75 \mathrm{ft}$ : some brown & 59 & $6 / 22 / 78$ \\
\hline
\end{tabular}

discoloration of gray tuff

$42.75-44.5 \mathrm{ft}$ : gray tuff 
TABLE A-II (cont)

\begin{tabular}{|c|c|c|c|}
\hline $\begin{array}{l}\text { Sample } \\
\text { Depth } \\
\text { (ft) }\end{array}$ & $\begin{array}{l}\text { Description and Comments } \\
\text { on Sample Collected }\end{array}$ & $\begin{array}{l}\text { Blows With } \\
400 \mathrm{lb} \text { Hammer }\end{array}$ & $\begin{array}{c}\text { Sampling } \\
\text { Date }\end{array}$ \\
\hline $44.5-46.5$ & Slightly moist gray tuff, no fractures & 81 & $6 / 22 / 78$ \\
\hline $46.5-48.5$ & Slightly moist gray tuff, no fractures & 81 & $6 / 22 / 78$ \\
\hline $48.5-50.5$ & $\begin{array}{l}\text { Slightly moist gray tuff, no fractures } \\
\text { but with slight brown stains on tuff }\end{array}$ & 61 & $6 / 22 / 78$ \\
\hline $50.5-52.5$ & Slightly moist gray tuff, no fractures & 74 & $6 / 22 / 78$ \\
\hline $52.5-54.5$ & Slightly moist gray tuff, no fractures & 80 & $6 / 22 / 78$ \\
\hline $54.5-55.5$ & Sample lost, drilling error & & \\
\hline $55.5-57.5$ & Slightly moist gray tuff, no fractures & 81 & $6 / 22 / 78$ \\
\hline $57.5-59.5$ & Slightly moist gray tuff, no fractures & 59 & $6 / 22 / 78$ \\
\hline $59.5-61.5$ & Slightly moist gray tuff, no fractures & 56 & $6 / 22 / 78$ \\
\hline $61.5-63.5$ & Slightly moist gray tuff, no fractures & 54 & $6 / 26 / 78$ \\
\hline $63.5-65.5$ & Slightly moist gray tuff, no fractures & 54 & $6 / 26 / 78$ \\
\hline $65.5-67.5$ & $\begin{array}{l}\text { Slightly moist gray tuff, no fractures } \\
\text { but with slight brown stains in tuff }\end{array}$ & 32 & $6 / 26 / 78$ \\
\hline $67.5-69.5$ & Slightly moist gray tuff, no fractures & 34 & $6 / 26 / 78$ \\
\hline $69.5-71.5$ & Slightly moist gray tuff, no fractures & 30 & $6 / 26 / 78$ \\
\hline $71.5-73.5$ & $\begin{array}{l}\text { Slightly moist gray tuff, no fractures } \\
\text { but with some brown pigmentation }\end{array}$ & 32 & $6 / 26 / 78$ \\
\hline $73.5-75.5$ & Slightly moist gray tuff, no fractures & 28 & $6 / 26 / 78$ \\
\hline $75.5-77.5$ & Slightly moist gray tuff, no fractures & 29 & $6 / 26 / 78$ \\
\hline $77.5-79.5$ & $\begin{array}{l}77.5-78.0 \mathrm{ft} \text { : slightly brownish-gray tuff } \\
78.0-79.5 \mathrm{ft} \text { : slightly moist gray tuff, no fractures }\end{array}$ & 28 & $6 / 26 / 78$ \\
\hline $79.5-81.5$ & 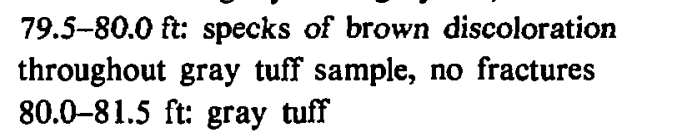 & 39 & $6 / 28 / 78$ \\
\hline $81.5-83.5$ & Gray tuff, no fractures & 33 & $6 / 28 / 78$ \\
\hline $83.5-85.5$ & Gray tuff, no fractures & 33 & $6 / 28 / 78$ \\
\hline $85.5-86.9$ & Drilling error, sample lost & - & $6 / 28 / 78$ \\
\hline $86.9-88.5$ & $\begin{array}{l}\text { Gray tuff with slight brown } \\
\text { discoloration, no fractures }\end{array}$ & 40 & $6 / 28 / 78$ \\
\hline $88.5-90.5$ & $\begin{array}{l}\text { Gray tuff with slight brown } \\
\text { discoloration, no fractures }\end{array}$ & 39 & $6 / 28 / 78$ \\
\hline $90.5-91.0$ & Drilling error, sample lost & - & $6 / 29 / 78$ \\
\hline $91.0-93.0$ & $\begin{array}{l}\text { Gray tuff with slight brown } \\
\text { discoloration, no fractures } \\
\text { (Rained } 6 / 28 \text {-morning of } 6 / 29 \text { ) }\end{array}$ & 43 & $6 / 29 / 78$ \\
\hline $93.0-95.0$ & Gray tuff, no fractures & 40 & $6 / 29 / 78$ \\
\hline $95.0-97.0$ & Gray tuff, no fractures & 43 & $6 / 29 / 78$ \\
\hline $97.0-99.0$ & Gray tuff, no fractures & 63 & $6 / 29 / 78$ \\
\hline $99.0-101.0$ & Gray tuff, no fractures & 87 & $6 / 29 / 78$ \\
\hline
\end{tabular}


TABLE A-III

SAMPLE LOG FOR HOLE I IN ABSORPTION BED 2 AT AREA T

[4.57 $\mathrm{m}$ from the east end of bed 2 and in center of bed]

\begin{tabular}{|c|c|c|c|c|}
\hline \multirow{2}{*}{$\begin{array}{l}\text { Sample } \\
\text { Depth } \\
\text { (ft) }\end{array}$} & \multirow[b]{2}{*}{$\begin{array}{l}\text { Description and Comments } \\
\text { on Sample Collected }\end{array}$} & \multicolumn{2}{|c|}{ Blows with } & \multirow[b]{2}{*}{$\begin{array}{c}\text { Sample } \\
\text { Date }\end{array}$} \\
\hline & & $\begin{array}{c}180 \mathrm{lb} \\
\text { Hammer }\end{array}$ & $\begin{array}{c}400 \mathrm{lb} \\
\text { Hammer }\end{array}$ & \\
\hline $3.0-4.0$ & Brown soil and tuff backfill and wood & - & - & $3 / 17 / 78$ \\
\hline $4.0-7.0$ & $\begin{array}{l}\text { Gravel-cobble layer, } \\
\text { no samples collected }\end{array}$ &. & - & $3 / 17 / 78$ \\
\hline $7.0-9.0$ & $\begin{array}{l}7.0-8.0 \mathrm{ft}: \text { gray tuff, } 1200 \mathrm{cpm} \text { alpha activity } \\
8.0-9.0 \mathrm{ft} \text { : brown fracture }\end{array}$ & 75 & - & $3 / 17 / 78$ \\
\hline $9.0-11.0$ & $\begin{array}{l}\text { Gray tuff, no fractures or } \\
\text { signs of alpha activity }\end{array}$ & 125 & - & $3 / 17 / 78$ \\
\hline $11.0-13.0$ & $\begin{array}{l}11.0-11.5 \mathrm{ft}: \text { gray tuff } \\
11.5-11.8 \mathrm{ft}: \text { fracture } \\
11.8-13.0 \mathrm{ft}: \text { gray tuff }\end{array}$ & - & - & $3 / 17 / 78$ \\
\hline $13.0-15.0$ & $\begin{array}{l}\text { Gray tuff, no apparent } \\
\text { fractures or alpha activity }\end{array}$ & - & - & $3 / 20 / 78$ \\
\hline $15.0-16.5$ & $\begin{array}{l}\text { 15.0-16.2 ft: gray tuff with no apparent } \\
\text { fractures or alpha activity }\end{array}$ & - & - & $3 / 20 / 78$ \\
\hline $16.5-17.5$ & $\begin{array}{l}16.2-16.5 \mathrm{ft} \text { : fracture with brown fill } \\
\text { Drilling error, sample lost }\end{array}$ & - & - & $3 / 20 / 78$ \\
\hline $17.5-19.5$ & $\begin{array}{l}\text { Gray tuff, no fractures, } \\
\text { no signs of alpha activity }\end{array}$ & 150 & - & $3 / 20 / 78$ \\
\hline $19.5-21.5$ & $\begin{array}{l}\text { Gray tuff, no fractures, } \\
\text { no signs of alpha activity }\end{array}$ & 150 & - & $3 / 20 / 78$ \\
\hline $21.5-23.5$ & $\begin{array}{l}\text { Gray tuff, no fractures, } \\
\text { no signs of alpha activity }\end{array}$ & 175 & - & $3 / 20 / 78$ \\
\hline $23.5-25.5$ & $\begin{array}{l}23.5-25.0 \mathrm{ft} \text { : gray tuff, no fractures, } \\
\text { no signs of alpha activity } \\
25.0-25.5 \mathrm{ft} \text { : fracture with a } 30^{\circ} \text { angle }\end{array}$ & 200 & - & $3 / 20 / 78$ \\
\hline $25.5-27.5$ & $\begin{array}{l}\text { Gray tuff, possible fractures } \\
\text { at } 25.8 \mathrm{ft}\end{array}$ & 150 & - & $3 / 21 / 78$ \\
\hline $27.5-29.5$ & $\begin{array}{l}\text { Gray tuff, no fractures, } \\
\text { no signs of alpha activity }\end{array}$ & 130 & - & $3 / 21 / 78$ \\
\hline $29.5-31.5$ & $\begin{array}{l}29.5-30.0 \mathrm{ft} \text { : gray tuff, no fractures } \\
\text { no signs of alpha activity } \\
30.0-31.5 \mathrm{ft} \text { : near-vertical fracture }\end{array}$ & 200 & - & $3 / 21 / 78$ \\
\hline $31.5-33.5$ & $\begin{array}{l}\text { Entire } 2 \mathrm{ft} \text { segment had higher clay } \\
\text { content and water content than previous segment }\end{array}$ & & & \\
\hline $31.5-33.5$ & $\begin{array}{l}31.5-32.0 \mathrm{ft} . \text { no fracture, gray tuff } \\
32.0-32.5 \mathrm{ft} \text {. brown-stained fracture } \\
32.5-33.0 \mathrm{ft} \text {. tuff between fractures } \\
33.0-33.5 \mathrm{ft} .60^{\circ} \text { fracture }\end{array}$ & 125 & - & $3 / 21 / 78$ \\
\hline
\end{tabular}


TABLE A-III (cont)

\begin{tabular}{|c|c|c|c|c|}
\hline \multirow{2}{*}{$\begin{array}{l}\text { Sample } \\
\text { Depth } \\
\text { (ft) }\end{array}$} & \multirow[b]{2}{*}{$\begin{array}{c}\text { Description and Comments } \\
\text { on Sample Collected }\end{array}$} & \multicolumn{2}{|c|}{ Blows with } & \multirow[b]{2}{*}{$\begin{array}{c}\text { Sample } \\
\text { Date }\end{array}$} \\
\hline & & $\begin{array}{l}180 \mathrm{lb} \\
\text { Hammer }\end{array}$ & $\begin{array}{l}400 \mathrm{lb} \\
\text { Hammer }\end{array}$ & \\
\hline \multirow[t]{2}{*}{$33.5-35.5$} & $\begin{array}{l}33.5-34.0 \mathrm{ft}: \text { gray tuff } \\
34.0-34.8 \mathrm{ft}: \text { brown fracture, } 25^{\circ}\end{array}$ & 80 & - & $3 / 21 / 78$ \\
\hline & $34.8-35.5 \mathrm{ft}:$ gray tuff & 85 & - & $3 / 21 / 78$ \\
\hline $35.5-37.5$ & $\begin{array}{l}\text { Gray tuff, no fractures, and } \\
\text { no alpha activity }\end{array}$ & 80 & - & $3 / 21 / 78$ \\
\hline $37.5-39.5$ & $\begin{array}{l}37.5-38.5 \mathrm{ft}: \text { brown tuff } \\
38.5-39.0 \mathrm{ft}: \text { fracture bend } \\
39.0-39.5 \mathrm{ft}: \text { gray tuff }\end{array}$ & 25 & - & $3 / 21 / 78$ \\
\hline $39.5-41.5$ & $\begin{array}{l}39.5-41.0 \mathrm{ft}: \text { gray tuff } \\
41.0-41.5 \mathrm{ft}: \text { brown fracture }\end{array}$ & 70 & - & $3 / 21 / 78$ \\
\hline $41.5-42.3$ & $\begin{array}{l}41.5-42 \mathrm{ft} \text { : brown-gray fracture } \\
42.0-42.3 \mathrm{ft} \text { : gray tuff } \\
\text { (Depth check; end of this hole } \\
\text { is } 42.25 \mathrm{ft} \text {, not } 43.5 \mathrm{ft} \text { : lost } 1.25 \mathrm{ft} \text { ) }\end{array}$ & 65 & - & $3 / 21 / 78$ \\
\hline $42.3-44.0$ & $\begin{array}{l}\text { Gray tuff on one-half of } \\
\text { core and brown fracture on other side }\end{array}$ & 150 & - & $3 / 22 / 78$ \\
\hline $44.0-46.0$ & $\begin{array}{l}\text { Color change from gray- } \\
\text { brown tuff to dark gray } \\
\text { at bottom of core }\end{array}$ & 223 & - & $3 / 22 / 78$ \\
\hline $46.0-46.5$ & $\begin{array}{l}\text { Drilling error, } \\
\text { no sample collected }\end{array}$ & & & \\
\hline $46.5-48.5$ & $\begin{array}{l}46.5-47.0 \mathrm{ft}: \text { gray-brown tuff } \\
47.0-48.5 \mathrm{ft}: \text { gray tuff }\end{array}$ & 235 & - & $3 / 22 / 78$ \\
\hline $48.5-50.5$ & $\begin{array}{l}48.5-50.0 \mathrm{ft}: \text { light brownish-gray tuff } \\
50.0-50.5 \mathrm{ft} \text { : light gray tuff }\end{array}$ & 130 & - & $3 / 22 / 78$ \\
\hline $50.5-52.5$ & $\begin{array}{l}50.5-51.5 \mathrm{ft} \text { : light gray to } \\
\text { brownish-gray tuff } \\
51.5-52.5 \mathrm{ft}: 1.5 \text {-in. wide fracture } \\
\text { with light brown fracture filling } \\
\text { in light gray tuff }\end{array}$ & - & 33 & $3 / 22 / 78$ \\
\hline $52.5-53.5$ & Drilling error, sample lost & - & - & $3 / 22 / 78$ \\
\hline $53.5-55.5$ & $\begin{array}{l}53.5-54.0 \mathrm{ft} \text { : light brown tuff } \\
54.0-55.5 \mathrm{ft} \text { : gray tuff }\end{array}$ & - & 73 & $3 / 22 / 78$ \\
\hline $55.5-57.5$ & Light gray tuff & - & 85 & $3 / 22 / 78$ \\
\hline $57.5-59.5$ & Light gray tuff & - & 75 & $3 / 22 / 78$ \\
\hline $59.5-61.5$ & Light gray tuff & - & 69 & $3 / 23 / 78$ \\
\hline $61.5-63.5$ & $\begin{array}{l}\text { Light gray tuff with a } \\
\text { few iron stains in matrix }\end{array}$ & - & 67 & $3 / 23 / 78$ \\
\hline $63.5-65.5$ & $\begin{array}{l}\text { Light gray tuff }(63.5-64.5 \mathrm{ft} \\
\text { increment got wet from rain on } 3 / 23 / 78)\end{array}$ & - & 50 & $3 / 24 / 78$ \\
\hline $65.5-67.5$ & Light gray tuff & - & 45 & $3 / 24 / 78$ \\
\hline $67.5-69.5$ & Light gray tuff & - & 38 & $3 / 24 / 78$ \\
\hline $69.5-71.5$ & Light gray tuff & - & 30 & $3 / 24 / 78$ \\
\hline
\end{tabular}


TABLE A-III (cont)

\begin{tabular}{c}
$\begin{array}{c}\text { Sample } \\
\text { Depth } \\
\text { (tt) }\end{array}$ \\
\hline $71.5-72.0$ \\
$72.0-74.0$ \\
$74.0-76.0$ \\
$76.0-78.0$ \\
$78.0-80.0$ \\
$80.0-81.0$ \\
$81.0-82.5$ \\
$82.5-84.5$ \\
\\
$84.5-86.5$ \\
$86.5-88.5$ \\
$88.5-90.5$ \\
$90.5-92.5$ \\
$92.5-93.0$ \\
$93.0-95.0$ \\
$95.0-97.0$ \\
$97.0-99.0$ \\
$99.0-101.0$
\end{tabular}

Description and Comments on Sample Collected

Drilling error, sample lost

Light gray tuff

Light gray tuff

Light gray tuff

Light gray tuff

Drilling error, sample lost

Light gray tuff

Light gray tuff $(82.5-82.8 \mathrm{ft}$

iricrement wetter than rest of core)

Light gray tuff

Light gray tuff

Light gray tuff

Light gray tuff

Drilling error, sample lost

(Sample depth check made)

Light gray tuff

Light gray tuff

Light gray tuff with high sand content

Light gray tuff with high sand content

and some small rocks in center of core
Blows with

\begin{tabular}{|c|c|c|}
\hline $\begin{array}{c}180 \mathrm{lb} \\
\text { Hammer }\end{array}$ & $\begin{array}{c}400 \mathrm{lb} \\
\text { Hammer }\end{array}$ & $\begin{array}{c}\text { Sample } \\
\text { Date }\end{array}$ \\
\hline - & 28 & $3 / 24 / 78$ \\
\hline - & 28 & $3 / 24 / 78$ \\
\hline - & - & $3 / 27 / 78$ \\
\hline - & 33 & $3 / 27 / 78$ \\
\hline - & 35 & $3 / 28 / 78$ \\
\hline - & - & $3 / 28 / 78$ \\
\hline - & - & $3 / 28 / 78$ \\
\hline - & - & $3 / 29 / 78$ \\
\hline - & 29 & $3 / 29 / 78$ \\
\hline - & 31 & $3 / 29 / 78$ \\
\hline - & 31 & $3 / 29 / 78$ \\
\hline - & 40 & $3 / 29 / 78$ \\
\hline - & - & $3 / 31 / 78$ \\
\hline - & 39 & $3 / 31 / 78$ \\
\hline - & 55 & $3 / 31 / 78$ \\
\hline - & 92 & $3 / 31 / 78$ \\
\hline - & 79 & $3 / 31 / 78$ \\
\hline
\end{tabular}




\section{TABLE A-IV}

\section{SAMPLE LOG FOR HOLE 2 IN ABSORPTION BED 2 AT AREA T}

[ $5.79 \mathrm{~m}$ from east end of bed 2 and in center of bed]

\begin{tabular}{|c|c|c|c|}
\hline $\begin{array}{l}\text { Sample } \\
\text { Depth } \\
\text { (ft) }\end{array}$ & $\begin{array}{l}\text { Description and Comments } \\
\text { on Samples Collected }\end{array}$ & $\begin{array}{r}180 \mathrm{lb} \\
\text { Hammer }\end{array}$ & $\begin{array}{c}\text { Sample } \\
\text { Date }\end{array}$ \\
\hline \multirow[t]{2}{*}{$2.5-4.5$} & 2.5-3.3 ft: gravel-sand mixture & 34 & $8 / 22 / 78$ \\
\hline & 3.3-4.5 ft: soil and tuff backfill & - & $8 / 22 / 78$ \\
\hline $4.5-8.0$ & Cobble-gravel layer & & \\
\hline $8.0-10.0$ & Light gray ruff, no fractures & 71 & $8 / 22 / 78$ \\
\hline $10.0-12.0$ & $\begin{array}{l}10.0-11.0 \mathrm{ft} \text { : light gray tuff, no fractures } \\
11.0-12.0 \mathrm{ft}: 3 \text { fractures } \\
\text { with brown filling in tuff }\end{array}$ & 78 & $8 / 22 / 78$ \\
\hline $12.0-14.0$ & $\begin{array}{l}12.0-12.5 \text { f:: } 2 \text { fractures } \\
\text { filled with brown clay }\end{array}$ & 100 & a \\
\hline $14.0-16.0$ & $\begin{array}{l}14.0-15.5 \mathrm{ft}: \text { gray tuff } \\
15.5-16.0 \mathrm{ft}: \text { clay filled fracture }\end{array}$ & 100 & a \\
\hline $16.0-18.0$ & $\begin{array}{l}16.0-16.5 \mathrm{ft}: \text { clay filled fracture } \\
16.5-17.0 \mathrm{ft} \text { : gray tuff } \\
17.0-17.5 \mathrm{ft}: \text { clay filled fracture } \\
17.5-18.0 \mathrm{ft}: \text { gray tuff }\end{array}$ & 121 & a \\
\hline $18.0-20.0$ & Light gray tuff, no fractures & 193 & a \\
\hline $20.0-22.0$ & Light gray tuff, no fractures & 306 & a \\
\hline $22.0-24.0$ & Light gray tuff, no fractures & 261 & a \\
\hline $24.0-26.0$ & $\begin{array}{l}24.0-24.5 \mathrm{ft}: \text { clay filled fracture } \\
24.5-25.5 \mathrm{ft}: \text { gray tuff } \\
25.5-26.0 \mathrm{ft}: \text { clay filled fracture }\end{array}$ & 151 & a \\
\hline $26.0-28.0$ & Gray-brown tuff, no fractures & 169 & $\mathbf{a}$ \\
\hline $28.0-30.0$ & $\begin{array}{l}28.0-29.0 \mathrm{ft}: \text { gray tuff } \\
29.0-30.0 \mathrm{ft}: 2 \text { clay filled fractures } \\
\text { surrounded by gray tuff }\end{array}$ & 96 & a \\
\hline $30.0-32.0$ & $\begin{array}{l}30.0-30.5 \mathrm{ft} \text { : rust colored clay filled fracture } \\
30.5-32.0 \mathrm{ft} \text { : gray tuff }\end{array}$ & 84 & a \\
\hline & $\begin{array}{l}32.0-32.5 \mathrm{ft}: \text { clay filled fracture } \\
32.5-34.0 \mathrm{ft}: \text { gray tuff }\end{array}$ & 70 & a \\
\hline $34.0-36.0$ & $\begin{array}{l}34.0-34.3 \mathrm{ft}: \text { clay filled fracture } \\
34.3-36.0 \mathrm{ft}: \text { gray tuff }\end{array}$ & 72 & a \\
\hline $36.0-38.0$ & Gray colored tuff, no fractures & 63 & $\mathbf{a}$ \\
\hline $38.0-40.0$ & $\begin{array}{l}38.0-38.5 \mathrm{ft} \text { : gray colored tuff, no fractures } \\
38.5-40.0 \mathrm{ft} \text { : large vertical clay filled fracture }\end{array}$ & 59 & a \\
\hline $40.0-42.0$ & $\begin{array}{l}40.0-41.0 \mathrm{ft}: \text { gray tuff } \\
41.0-41.5 \mathrm{ft}: \text { clay filled fracture } \\
41.5-42.0 \mathrm{ft}: \text { gray tuff }\end{array}$ & 41 & a \\
\hline $42.0-44.0$ & Gray tuff, no fractures & 54 & a \\
\hline $44.0-44.5$ & Drilling error, sample lost & - & \\
\hline $44.5-46.5$ & Gray tuff, no fractiures & 60 & $\mathbf{a}$ \\
\hline $46.5-48.5$ & $\begin{array}{l}46.5-48.0 \mathrm{ft}: \text { gray tuff, no fractures } \\
48.0-48.5 \mathrm{ft}: \text { clay filled fracture }\end{array}$ & 64 & $\mathbf{a}$ \\
\hline
\end{tabular}


TABLE A-IV (cont)

\begin{tabular}{|c|c|c|c|}
\hline $\begin{array}{l}\text { Sample } \\
\text { Depth } \\
\text { (ft) }\end{array}$ & $\begin{array}{c}\text { Description and Comments } \\
\text { on Samples Collected }\end{array}$ & $\begin{array}{c}180 \mathrm{lb} \\
\text { Hammer }\end{array}$ & $\begin{array}{c}\text { Sample } \\
\text { Date } \\
\end{array}$ \\
\hline $48.5-50.5$ & Gray tuff, no fractures & 76 & a \\
\hline $50.5-52.5$ & Gray tuff, no fractures & 65 & $\mathbf{a}$ \\
\hline $52.5-54.5$ & $\begin{array}{l}52.5-53.0 \mathrm{ft} \text { : clay filled fracture } \\
53.0-54.0 \mathrm{ft} \text { : gray tuff } \\
54.0-54.5 \mathrm{ft}: \text { clay filled fracture }\end{array}$ & 65 & $\mathbf{a}$ \\
\hline $54.5-56.5$ & Gray tuff, no fractures & 64 & $\mathbf{a}$ \\
\hline $56.5-58.5$ & $\begin{array}{l}\text { Gray tuff, fracture in entire } \\
\text { sample length; entire sample is moist }\end{array}$ & $\begin{array}{l}46 \\
40\end{array}$ & $\begin{array}{l}\mathbf{a} \\
\mathbf{a}\end{array}$ \\
\hline $60.5-62.5$ & $\begin{array}{l}\text { Gray tuff, fracture in entire } \\
\text { sample length; entire sample is moist }\end{array}$ & 39 & a \\
\hline $62.5-64.5$ & $\begin{array}{l}62.5-63.0 \mathrm{ft} \text { : clay filled fracture } \\
63.0-64.5 \mathrm{ft} \text { : gray tuff, no fractures }\end{array}$ & 38 & $\mathbf{a}$ \\
\hline $64.5-66.5$ & Gray tuff, no fractures & 28 & $\mathbf{a}$ \\
\hline $66.5-68.5$ & Gray tuff, no fractures & 29 & $\mathbf{a}$ \\
\hline $68.5-70.5$ & Gray tuff, no fractures & 29 & $\mathbf{a}$ \\
\hline $70.5-72.5$ & Gray tuff, no fractures & 32 & a \\
\hline $72.5-74.5$ & Gray tuff, no fractures & 36 & $\mathbf{a}$ \\
\hline $74.5-76.5$ & Gray tuff, no fractures & 37 & $\mathbf{a}$ \\
\hline $76.5-78.5$ & Gray tuff, no fractures & 39 & $\mathbf{a}$ \\
\hline $78.5-82.5$ & Drilling error, sample lost & - & $10 / 3 / 78$ \\
\hline $82.5-84.5$ & Gray tuff, no fractures & 33 & $10 / 3 / 78$ \\
\hline $84.5-86.5$ & $\begin{array}{l}84.5-84.8 \mathrm{ft} \text { : clay filled fracture } \\
84.8-86.5 \mathrm{ft}: \text { gray tuff, no fractures }\end{array}$ & 37 & $10 / 3 / 78$ \\
\hline $86.5-88.5$ & Gray tuff, no fractures & 33 & $10 / 3 / 78$ \\
\hline $88.5-90.5$ & Gray tuff, no fractures & 27 & $10 / 3 / 78$ \\
\hline $90.5-92.5$ & Gray tuff, no fractures & 53 & $10 / 4 / 78$ \\
\hline $92.5-94.5$ & Gray tuff, no fractures & 53 & $10 / 4 / 78$ \\
\hline $94.5-96.5$ & Grayish-brown tuff, no fractures & 43 & $10 / 5 / 78$ \\
\hline $96.5-98.5$ & Gray tuff, no fractures & 54 & $10 / 5 / 78$ \\
\hline $98.5-100.5$ & Grayish-brown tuff, no fractures & 57 & $10 / 5 / 78$ \\
\hline
\end{tabular}

${ }^{\mathrm{a}}$ Exact sampling date between August 22 and October 3, 1978 unknown. 


\section{APPENDIX B}

SAMPLE WEIGHT, WATER CONTENT, AND RADIONUCLIDE CONCENTRATIONS FOR SAMPLES COLLECTED IN 1978 AT AREA T 
SAMPLE WEIGHT, WATER CONTENT, AND PLUTONIUM AND ${ }^{241}$ Am CONCENTRATIONS OF SAMPLES FROM HOLE 1 IN ABSORPTION BED 1

\begin{tabular}{|c|c|c|c|c|c|}
\hline \multicolumn{2}{|c|}{ Sample Depth Increment } & \multirow{2}{*}{$\begin{array}{c}\text { Sample } \\
\text { Oven-Dry } \\
\text { Weight } \\
\text { (g) }\end{array}$} & \multirow{2}{*}{$\begin{array}{c}\text { Water } \\
\text { Content } \\
(\%)\end{array}$} & \multirow{2}{*}{$\begin{array}{c}\text { Pu Conc (pCi/g) } \\
\pm \text { Analytical Error } \\
(\%)\end{array}$} & \multirow{2}{*}{$\begin{array}{c}{ }^{241} \text { Am Conc (pCi/g) } \\
\pm \text { Analytical Error } \\
(\%)\end{array}$} \\
\hline$(\mathrm{ft})$ & (m) & & & & \\
\hline $2.5-3.0$ & $0.76-0.91$ & 671.89 & 16.83 & $N^{a}$ & $2.83 \pm 3$ \\
\hline $3.0-3.5$ & $0.91-1.07$ & 1162.08 & 15.79 & ND & $2.66 \pm 4$ \\
\hline $3.5-4.0$ & $1.07-1.22$ & 1173.04 & 15.66 & ND & $0.73 \pm 11$ \\
\hline $4.5-5.0$ & $1.37-1.52$ & 780.18 & 20.08 & ND & $2.35 \pm 4$ \\
\hline $5.0-5.5$ & $1.52-1.68$ & 888.34 & 20.32 & ND & $2.52 \pm 4$ \\
\hline $5.5-6.0$ & $1.68-1.83$ & 1071.65 & 20.26 & ND & $0.66 \pm 12$ \\
\hline $6.5-7.0$ & $1.98-2.13$ & 682.51 & 15.87 & ND & $661.3 \pm 0$ \\
\hline $7.0-7.5$ & $2.13-2.29$ & 1194.43 & 17.32 & ND & $457.0 \pm 0$ \\
\hline $7.5-7.75$ & $2.29-2.36$ & 865.43 & 18.26 & ND & $161.7 \pm 0$ \\
\hline $7.75-8.0$ & $2.36-2.44$ & 947.53 & 7.76 & ND & $380.6 \pm 0$ \\
\hline $10.5-11.0$ & $3.20-3.35$ & 1034.99 & 17.06 & $39910 \pm 5$ & $16443 \pm 0$ \\
\hline $11.0-11.5$ & $3.35-3.51$ & 934.46 & 13.92 & $8777 \pm 5$ & $2105 \pm 0$ \\
\hline $11.5-12.0$ & $3.51-3.66$ & 929.22 & 12.34 & $6532 \pm 6$ & $1302 \pm 0$ \\
\hline $12.0-12.5$ & $3.66-3.81$ & 983.27 & 12.96 & $2008 \pm 12$ & $4058 \pm 0$ \\
\hline $12.5-13.0$ & $3.81-3.96$ & 784.44 & 26.49 & $2600 \pm 7$ & $855.4 \pm 1$ \\
\hline $13.0-13.5$ & $3.96-4.11$ & 775.90 & 25.35 & $1322 \pm 7$ & $620.4 \pm 0$ \\
\hline $14.5-15.0$ & $4.42-4.57$ & 813.40 & 23.18 & $933.0 \pm 8$ & $696.4 \pm 0$ \\
\hline $15.0-15.5$ & $4.57-4.72$ & 937.35 & 25.06 & $659.0 \pm 8$ & $397.0 \pm 1$ \\
\hline $15.5-16.0$ & $4.72-4.88$ & 984.80 & 25.16 & $1508 \pm 8$ & $776.5 \pm 1$ \\
\hline $16.0-16.5$ & $4.88-5.03$ & 974.00 & 25.60 & $2240 \pm 8$ & $1649 \pm 0$ \\
\hline $16.5-17.0$ & $5.03-5.18$ & 833.38 & 24.27 & $6406 \pm 6$ & $1943 \pm 0$ \\
\hline $17.0-17.5$ & $5.18-5.33$ & 964.42 & 25.48 & $2008+1$ & $390.6 \pm 1$ \\
\hline $17.5-18.0$ & $5.33-5.49$ & 935.82 & 25.52 & $1365:: 0$ & $645.0 \pm 0$ \\
\hline $18.0-18.5$ & $5.49-5.64$ & 1025.36 & 23.62 & $1160 \pm 12$ & $1392 \pm 0$ \\
\hline $18.5-19.0$ & $5.64-5.79$ & 669.88 & 24.17 & $668.0 \pm 10$ & $802.2 \pm 0$ \\
\hline $19.0-19.5$ & $5.79-5.94$ & 871.64 & 25.18 & $1050 \pm 7$ & $585.4 \pm 1$ \\
\hline $19.5-20.0$ & $5.94-6.10$ & 881.65 & 26.27 & $852.9 \pm 8$ & $470.1 \pm 1$ \\
\hline $20.0-20.5$ & $6.10-6.25$ & 820.90 & 29.33 & $9536 \pm 7$ & $10419 \pm 0$ \\
\hline $20.5-21.0$ & $6.25-6.40$ & 918.93 & 24.14 & $461.5 \pm 11$ & $639.4 \pm 0$ \\
\hline $21.0-21.5$ & $6.40-6.55$ & 1031.62 & 25.47 & $1040 \pm 7$ & $277.0 \pm 1$ \\
\hline $21.5-22.0$ & $6.55-6.71$ & 981.86 & 14.71 & $2309 \pm 10$ & $3811 \pm 0$ \\
\hline $22.0-22.5$ & $6.71-6.86$ & 787.76 & 6.86 & $586.6 \pm 6$ & $104.7 \pm 1$ \\
\hline $22.5-23.0$ & $6.86-7.01$ & 898.46 & 10.83 & $338.3 \pm 8$ & $247.5 \pm 0$ \\
\hline $23.0-23.5$ & $7.01-7.16$ & 951.02 & 9.92 & $346.2 \pm 6$ & $41.84 \pm 1$ \\
\hline $23.5-24.0$ & $7.16-7.32$ & 947.39 & 9.81 & $260.6 \pm 7$ & $46.85 \pm 1$ \\
\hline $24.0-24.5$ & $7.32-7.47$ & 913.62 & 10.10 & $372.6 \pm 6$ & $55.09 \pm 1$ \\
\hline $24.5-25.0$ & $7.47-7.62$ & 889.03 & 10.96 & $242.7 \pm 7$ & $91.00 \pm 1$ \\
\hline
\end{tabular}

${ }^{\mathrm{N}} \mathrm{ND}$ signifies non-detectable levels of radionuclides at the 3 sigma probability level: $<30 \mathrm{pCi}$ plutonium $/ \mathrm{g}$ and $<0.8$ $\mathrm{pC.i}{ }^{241} \mathrm{Am} / \mathrm{g}$. 
TABLE B-I (cont)

\begin{tabular}{|c|c|c|c|c|c|}
\hline \multicolumn{2}{|c|}{ Sample Depth Increment } & \multirow{2}{*}{$\begin{array}{c}\text { Samnle } \\
\text { Oven-Dry } \\
\text { Weight } \\
\text { (g) } \\
\end{array}$} & \multirow{2}{*}{$\begin{array}{c}\text { Water } \\
\text { Content } \\
(\%) \\
\end{array}$} & \multirow{2}{*}{$\begin{array}{c}\text { Pu Conc (pCi/g) } \\
\pm \text { Analytical Error } \\
(\%)\end{array}$} & \multirow{2}{*}{$\begin{array}{c}{ }^{241} \text { Am Conc (pCi/g) } \\
\pm \text { Analytical Error } \\
(\%)\end{array}$} \\
\hline$(\mathrm{ft})$ & (m) & & & & \\
\hline $25.0-25.5$ & $7.62-7.77$ & 959.34 & 10.29 & $149.6 \pm 7$ & $78.41 \pm 1$ \\
\hline $25.5-26.0$ & $7.77-7.92$ & 995.67 & 11.50 & $151.8 \pm 7$ & $89.6 \pm 0$ \\
\hline $26.0-26.5$ & $7.92-8.08$ & 936.22 & 11.38 & $276.0 \pm 8$ & $145.9 \pm 1$ \\
\hline $26.5-27.0$ & $8.08-8.23$ & 858.50 & 12.86 & $288.8 \pm 8$ & $150.4 \pm 1$ \\
\hline $27.0-27.5$ & $8.23-8.38$ & 965.24 & 12.92 & $239.5 \pm 8$ & $143.6 \pm 1$ \\
\hline $27.5-28.0$ & $8.38-8.53$ & 926.18 & 12.96 & $158.8 \pm 16$ & $252.3 \pm 0$ \\
\hline $28.0-28.5$ & $8.53-8.69$ & 928.12 & 13.51 & $470.0 \pm 12$ & $708.6 \pm 0$ \\
\hline $28.5-29.0$ & $8.69-8.84$ & 800.59 & 14.63 & $1712 \pm 8$ & $10 i 4 \pm 1$ \\
\hline $29.0-29.5$ & $8.84-8.99$ & 946.47 & 15.26 & $2629 \pm 7$ & $1728 \pm 0$ \\
\hline $29.5-30.0$ & $8.99-9.14$ & 902.30 & 15.54 & $1881 \pm 10$ & $2694 \pm 0$ \\
\hline $30.0-30.5$ & $9.14-9.30$ & 825.08 & 16.41 & $2939 \pm 7$ & $2137 \pm 0$ \\
\hline $30.5-31.0$ & $9.30-9.45$ & 922.35 & 18.78 & $5352 \pm 7$ & $4218 \pm 0$ \\
\hline $31.0-31.5$ & $9.45-9.60$ & 966.86 & 27.60 & $22590 \pm 9$ & $44354 \pm 0$ \\
\hline $31.5-32.0$ & $9.60-9.75$ & 854.09 & 28.05 & $31729 \pm 8$ & $53201 \pm 0$ \\
\hline $32.0-32.5$ & $9.75-9.91$ & 996.75 & 27.66 & $11020 \pm 9$ & $16568 \pm 0$ \\
\hline $32.5-33.0$ & $9.91-10.06$ & 1024.29 & 18.39 & $9648 \pm 0$ & $30723 \pm 0$ \\
\hline $33.0-33.5$ & $10.06-10.21$ & 888.90 & 30.02 & $8275 \pm 0$ & $8727 \pm 0$ \\
\hline $33.5-34.0$ & $10.21-10.36$ & 916.60 & 28.96 & $2125 \pm 10$ & $3249 \pm 0$ \\
\hline $34.0-34.5$ & $10.36-10.52$ & 873.90 & 27.43 & $2271 \pm 7$ & $1781 \pm 0$ \\
\hline $34.5-35.0$ & $10.52-10.67$ & 850.55 & 21.92 & $2513 \pm 12$ & $3963 \pm 0$ \\
\hline $35.0-35.5$ & $10.67-10.82$ & 875.00 & 22.54 & $1313 \pm 10$ & $1552 \pm 0$ \\
\hline $35.5-36.0$ & $10.82-10.97$ & 806.58 & 23.04 & $1355 \pm 8$ & $892.7 \pm 1$ \\
\hline $36.0-36.5$ & $10.97-11.13$ & 901.10 & 16.08 & $593.8 \pm 6$ & $163.7 \pm 1$ \\
\hline $36.5-37.0$ & $11.13-11.28$ & 873.31 & 15.31 & $1045 \pm 7$ & $444.4 \pm 1$ \\
\hline $37.0-37.5$ & $11.28-11.43$ & 950.77 & 12.52 & $881.3 \pm 6$ & $253.9 \pm 1$ \\
\hline $37.5-38.0$ & $11.43-11.58$ & 861.71 & 9.71 & $549.2 \pm 6$ & $83.57 \pm 1$ \\
\hline $38.0-38.5$ & $11.58-11.73$ & -37.48 & 9.61 & $550.7 \pm 6$ & $71.69 \pm 1$ \\
\hline $38.5-39.0$ & $11.73-11.89$ & 849.82 & 10.11 & $874.6 \pm 7$ & $407.4 \pm 1$ \\
\hline $39.0-39.5$ & $11.89-12.04$ & 939.73 & 9.18 & $668.4 \pm 6$ & $75.10 \pm 1$ \\
\hline $39.5-40.0$ & $12.04-12.19$ & 847.94 & 8.39 & $693.8 \pm 6$ & $59.92 \pm 1$ \\
\hline $40.0-40.5$ & $12.19-12.34$ & 955.06 & 8.64 & $1146 \pm 6$ & $114.2 \pm 1$ \\
\hline $40.5-41.0$ & $12.34-12.50$ & 929.08 & 6.70 & $299.4 \pm 7$ & $125.3 \pm 1$ \\
\hline $41.0-41.5$ & $12.50-12.65$ & 909.66 & 7.53 & $332.9 \pm 6$ & $42.26 \pm 1$ \\
\hline $41.5-42.0$ & $12.65-12.80$ & 902.51 & 7.55 & $325.1 \pm 6$ & $40.29 \pm 1$ \\
\hline $42.0-42.5$ & $12.80-12.95$ & 924.10 & 7.43 & $303.2 \pm 7$ & $38.58 \pm 1$ \\
\hline $42.5-43.0$ & $12.95-13.11$ & 898.04 & 7.36 & $307.6 \pm 7$ & $103.1 \pm 1$ \\
\hline $43.0-43.5$ & $13.11-13.26$ & 898.51 & 7.56 & $165.8 \pm 7$ & $35.81 \pm 1$ \\
\hline $43.5-44.0$ & $13.26-13.41$ & 886.68 & 7.54 & $154.4 \pm 7$ & $38.11 \pm 1$ \\
\hline $44.0-44.5$ & $13.41-13.56$ & 882.46 & 7.31 & $175.2 \pm 7$ & $41.45 \pm 1$ \\
\hline $44.5-45.0$ & $13.56-13.72$ & 941.85 & 7.86 & $197.7 \pm 7$ & $64.92 \pm 1$ \\
\hline $45.0-45.5$ & $13.72-13.87$ & 936.43 & 7.72 & $192.2 \pm 7$ & $47.40 \pm 1$ \\
\hline $45.5-46.0$ & $13.87-14.02$ & 881.45 & 7.76 & $272.7 \pm 7$ & $57.66 \pm 1$ \\
\hline $46.0-46.5$ & $14.02-14.17$ & 848.99 & 7.77 & $335.0 \pm 6$ & $72.10 \pm 1$ \\
\hline
\end{tabular}


TABLE B-I (cont)

\begin{tabular}{|c|c|c|c|c|c|}
\hline \multicolumn{2}{|c|}{ Sample Depth Increment } & \multirow{2}{*}{$\begin{array}{c}\text { Sample } \\
\text { Oven-Dry } \\
\text { Weight } \\
\text { (g) }\end{array}$} & \multirow{2}{*}{$\begin{array}{c}\text { Water } \\
\text { Content } \\
\text { (\%) }\end{array}$} & \multirow{2}{*}{$\begin{array}{c}\text { Pu Conc (pCi/g) } \\
\pm \text { Analytical Error } \\
(\%)\end{array}$} & \multirow{2}{*}{$\begin{array}{c}{ }^{241} \text { Am Conc }(\mathrm{pCi} / \mathrm{g}) \\
\pm \text { Analytical Error } \\
(\%)\end{array}$} \\
\hline (ft) & (m) & & & & \\
\hline $46.5-47.0$ & $14.17-14.33$ & 645.25 & 7.21 & $146.9 \pm 9$ & $65.29 \pm 1$ \\
\hline $47.0-47.5$ & $14.33-14.48$ & 907.69 & 7.68 & $165.8 \pm 7$ & $48.49 \pm 1$ \\
\hline $47.5-48.0$ & $14.48-14.63$ & 874.66 & 8.15 & $161.6 \pm 7$ & $49.87 \pm 1$ \\
\hline $48.0-48.5$ & $14.63-14.78$ & 949.79 & 8.33 & $144.0 \pm 8$ & $55.52 \pm 1$ \\
\hline $48.5-49.0$ & $14.78-14.94$ & 913.59 & 8.37 & $142.7 \pm 7$ & $62.03 \pm 1$ \\
\hline $49.0-49.5$ & $14.94-15.09$ & 930.72 & 8.55 & $114.6 \pm 8$ & $35.31 \pm 1$ \\
\hline $49.5-50.0$ & $15.09-15.24$ & 943.96 & 8.93 & $124.1 \pm 8$ & $31.16 \pm 1$ \\
\hline $50.0-50.5$ & $15.24-15.39$ & 991.03 & 8.90 & $101.8 \pm 8$ & $31.31 \pm 1$ \\
\hline $50.5-51.0$ & $15.39-15.54$ & 988.81 & 8.75 & $61.78 \pm 10$ & $37.42 \pm 1$ \\
\hline $51.0-51.5$ & $15.54-15.70$ & 918.91 & 8.57 & $73.72 \pm 12$ & $50.89 \pm 1$ \\
\hline $51.5-52.0$ & $15.70-15.85$ & 949.64 & 9.27 & $109.1 \pm 8$ & $52.73 \pm 1$ \\
\hline $52.0-52.5$ & $15.85-16.00$ & 944.23 & 9.83 & $38.42 \pm 16$ & $67.74 \pm 1$ \\
\hline $52.5-53.0$ & $16.00-16.15$ & 634.23 & 9.51 & $123.1 \pm 9$ & $68.25 \pm 1$ \\
\hline $53.0-53.5$ & $16.15-16.31$ & 744.49 & 9.51 & $74.21 \pm 10$ & $70.8 \pm 1$ \\
\hline $53.5-54.0$ & $16.31-16.46$ & 886.86 & 9.82 & $54.87 \pm 11$ & $62.90 \pm 1$ \\
\hline $54.0-54.5$ & $16.46-16.61$ & 803.26 & 10.25 & $75.89 \pm 9$ & $56.29 \pm 1$ \\
\hline $54.5-55.0$ & $16.61-16.76$ & 878.48 & 10.22 & $58.38 \pm 11$ & $71.13 \pm 1$ \\
\hline $55.0-55.5$ & $16.76-16.92$ & 932.01 & 11.27 & $365.1 \pm 8$ & $249.7 \pm 1$ \\
\hline $55.5-56.0$ & $16.92-17.07$ & 968.89 & 10.38 & $54.4 \pm 17$ & $106.3 \pm 1$ \\
\hline $56.0-56.5$ & $17.07-17.22$ & 937.90 & 10.14 & $81.68 \pm 12$ & $73.12 \pm 1$ \\
\hline $56.5-57.0$ & $17.22-17.37$ & 932.76 & 9.82 & $81.77 \pm 9$ & $66.69 \pm 1$ \\
\hline $57.0-57.5$ & $17.37-17.53$ & 949.54 & 10.34 & $64.14 \pm 10$ & $55.95 \pm 1$ \\
\hline $57.5-58.0$ & $17.53-17.68$ & 910.09 & 11.09 & ND & $56.42 \pm 1$ \\
\hline $58.0-58.5$ & $17.68-17.83$ & 904.72 & 11.22 & $98.40 \pm 8$ & $57.64 \pm 1$ \\
\hline $58.5-59.0$ & $17.83-17.98$ & 929.50 & 10.41 & $136.1 \pm 8$ & $65.28 \pm 1$ \\
\hline $59.0-59.5$ & $17.98-18.14$ & 910.62 & 10.46 & $172.9 \pm 7$ & $66.96 \pm 1$ \\
\hline $59.5-60.0$ & $18.14-18.29$ & 942.20 & 12.01 & $652.6 \pm 6$ & $121.4 \pm 1$ \\
\hline $60.0-60.5$ & $18.29-18.44$ & 985.82 & 9.52 & $165.8 \pm 7$ & $66.24 \pm 1$ \\
\hline $60.5-61.0$ & $18.44-18.59$ & 868.54 & - & $126.0 \pm 8$ & $58.55 \pm 1$ \\
\hline $61.0-61.5$ & $18.59-18.75$ & 941.33 & 10.78 & $160.0 \pm 8$ & $68.62 \pm 1$ \\
\hline $61.5-62.0$ & $18.75-18.90$ & 938.40 & 10.02 & $185.0 \pm 7$ & $62.02 \pm 1$ \\
\hline $62.0-62.5$ & $18.90-19.05$ & 919.97 & 10.68 & $124.5 \pm 8$ & $50.90 \pm 1$ \\
\hline $62.5-63.0$ & $19.05-19.20$ & 884.55 & 10.00 & $65.75 \pm 11$ & $68.17 \pm 1$ \\
\hline $63.0-63.5$ & $19.20-19.35$ & 920.21 & 10.01 & $133.5 \pm 8$ & $62.98 \pm 1$ \\
\hline $63.5-64.0$ & $19.35-19.51$ & 962.11 & 9.61 & $96.25 \pm 9$ & $76.73 \pm 1$ \\
\hline $64.0-64.5$ & $19.51-19.66$ & 916.74 & 9.72 & $187.3 \pm 8$ & $134.4 \pm 1$ \\
\hline $64.5-65.0$ & $19.66-19.81$ & 741.42 & 9.29 & $58.41 \pm 24$ & $138.6 \pm 1$ \\
\hline $65.0-65.5$ & $19.81-19.96$ & 931.42 & 8.06 & ND & $67.40 \pm 1$ \\
\hline $65.5-66.0$ & $19.96-20.12$ & 912.61 & 7.71 & ND & $54.48 \pm 1$ \\
\hline $66.0-66.5$ & $20.12-20.27$ & 902.23 & 8.20 & $37.88 \pm 19$ & $56.86 \pm 1$ \\
\hline $66.5-67.0$ & $20.27-20.42$ & 993.91 & 8.46 & $87.19 \pm 15$ & $152.3 \pm 0$ \\
\hline $67.0-67.5$ & $20.42-20.57$ & 864.81 & 9.01 & ND & $58.20 \pm 1$ \\
\hline $67.5-68.0$ & $20.57-20.73$ & 881.11 & 9.92 & ND & $160.7 \pm 0$ \\
\hline
\end{tabular}


TABLE B-I (cont)

\begin{tabular}{|c|c|c|c|c|c|}
\hline \multicolumn{2}{|c|}{ Sample Depth Increment } & \multirow{2}{*}{$\begin{array}{l}\text { Oven-Dry } \\
\text { Weight } \\
\text { (g) }\end{array}$} & \multirow{2}{*}{$\begin{array}{l}\text { Water } \\
\text { Content } \\
(\%)\end{array}$} & \multirow{2}{*}{$\begin{array}{c}\text { Pu Conc }(\mathrm{pCi} / \mathrm{g}) \\
\pm \text { Analytical Error } \\
(\%) \\
\end{array}$} & \multirow{2}{*}{$\begin{array}{c}{ }^{241} \mathrm{Am} \text { Conc }(\mathrm{pCi} / \mathrm{g}) \\
\pm \text { Analytical Error } \\
(\%)\end{array}$} \\
\hline$(\mathrm{ft})$ & (m) & & & & \\
\hline $68.0-68.5$ & $20.73-20.88$ & 893.85 & 9.98 & $169.1 \pm 10$ & $178.6 \pm 0$ \\
\hline $68.5-69.0$ & $20.88-21.03$ & 753.44 & 10.23 & $429.7 \pm 7$ & $220.9 \pm 1$ \\
\hline $69.0-69.5$ & $21.02-21.18$ & 905.61 & 10.10 & $550.7 \pm 7$ & $320.9 \pm 0$ \\
\hline $69.5-70.0$ & $21.18-21.34$ & 885.89 & 10.17 & $1833 \pm 6$ & $497 \pm 1$ \\
\hline $70.0-70.5$ & $21.34-21.49$ & 928.29 & 8.87 & $302.1 \pm 7$ & $53.30 \pm 1$ \\
\hline $70.5-71.0$ & $21.49-21.64$ & 789.80 & 8.85 & $476.6 \pm 6$ & $145.7 \pm 1$ \\
\hline $71.0-71.5$ & $21.64-21.79$ & 967.36 & 8.90 & $96.32 \pm 9$ & $24.89 \pm 1$ \\
\hline $71.5-72.0$ & $21.79-21.95$ & 961.77 & 9.23 & $64.93 \pm 10$ & $25.58 \pm 1$ \\
\hline $72.0-72.5$ & $21.95-22.10$ & 920.67 & 9.42 & $84.72 \pm 8$ & $33.63 \pm 1$ \\
\hline $72.5-73.0$ & $22.10-22.25$ & 927.86 & 10.01 & $188.2 \pm 7$ & $72.45 \pm 1$ \\
\hline $73.0-73.5$ & $22.25-22.40$ & 867.95 & 8.86 & $112.1 \pm 8$ & $40.03 \pm 1$ \\
\hline $73.5-74.0$ & $22.40-22.56$ & 900.87 & 8.55 & $91.75 \pm 8$ & $40.27 \pm 1$ \\
\hline $74.0-74.5$ & $22.56-22.71$ & 931.44 & 8.81 & $113.6 \pm 8$ & $40.79 \pm 1$ \\
\hline $74.5-75.0$ & $22.71-22.86$ & 957.95 & 8.58 & $105.9 \pm 8$ & $48.46 \pm 1$ \\
\hline $75.0-75.5$ & $22.86-23.01$ & 883.10 & 9.04 & $118.9 \pm 8$ & $30.24 \pm 1$ \\
\hline $75.5-76.0$ & $23.01-23.16$ & 909.17 & 8.71 & $103.5 \pm 8$ & $28.46 \pm 1$ \\
\hline $76.0-76.5$ & $23.16-23.32$ & 946.27 & 8.68 & $69.26 \pm 9$ & $26.37 \pm 1$ \\
\hline $76.5-77.0$ & $23.32-23.47$ & 950.36 & 10.44 & $64.69 \pm 10$ & $44.24 \pm 1$ \\
\hline $77.0-77.5$ & $23.47-23.62$ & 935.15 & 9.25 & $146.4 \pm 7$ & $28.95 \pm 1$ \\
\hline $77.5-78.0$ & $23.62-23.77$ & 902.78 & 7.67 & $142.7 \pm 7$ & $27.99 \pm 1$ \\
\hline $78.0-78.5$ & $23.77-23.93$ & 929.16 & 11.31 & $103.5 \pm 8$ & $30.64 \pm 1$ \\
\hline $78.5-79.0$ & $23.93-24.08$ & 824.31 & 28.73 & $107.0 \pm 8$ & $40.30 \pm 1$ \\
\hline $79.0-79.5$ & $24.08-24.23$ & 911.02 & 24.29 & $102.0 \pm 8$ & $29.01 \pm 1$ \\
\hline $79.5-80.0$ & $24.23-24.38$ & 937.10 & 9.98 & $48.07 \pm 11$ & $31.28 \pm 1$ \\
\hline $80.0-80.5$ & $24.38-2.4 .54$ & 970.89 & 14.97 & $115.6 \pm 8$ & $35.78 \pm 1$ \\
\hline $80.5-81.0$ & $24.54-24.69$ & 852.32 & 7.14 & $88.77 \pm 9$ & $52.49 \pm 1$ \\
\hline $81.0-81.5$ & $24.69-24.84$ & 933.27 & 7.87 & $103.2 \pm 8$ & $35.98 \pm 1$ \\
\hline $81.5-82.0$ & $24.84-24.99$ & 958.67 & 8.10 & $117.8 \pm 8$ & $38.84 \pm 1$ \\
\hline $82.0-82.5$ & $24.99-25.15$ & 894.67 & 7.68 & $144.5 \pm 7$ & $39.22 \pm 1$ \\
\hline $82.5-83.0$ & $25.15-25.30$ & 832.67 & 7.17 & $89.50 \pm 9$ & $65.67 \pm 1$ \\
\hline $83.0-83.5$ & $25.30-25.45$ & 916.88 & 7.69 & $113.3 \pm 8$ & $48.84 \pm 1$ \\
\hline $83.5-84.0$ & $25.45-25.60$ & 913.88 & 6.94 & $111.2 \pm 9$ & $56.76 \pm 1$ \\
\hline $84.0-84.5$ & $25.60-25.76$ & 947.42 & 7.73 & $128.0 \pm 7$ & $54.63 \pm 1$ \\
\hline $86.0-86.5$ & $26.21-26.37$ & 866.52 & 9.93 & $93.62 \pm 9$ & $66.79 \pm 1$ \\
\hline $86.5-87.0$ & $26.37-26.52$ & 919.86 & 7.46 & $116.7 \pm 8$ & $52.02 \pm 1$ \\
\hline $87.0-87.5$ & $26.52-26.67$ & 958.70 & 7.60 & $84.30 \pm 9$ & $53.00 \pm 1$ \\
\hline $87.5-88.0$ & $26.67-26.82$ & 918.94 & 7.29 & $56.60 \pm 15$ & $56.63 \pm 1$ \\
\hline $88.0-88.5$ & $26.82-26.97$ & 525.67 & 5.08 & $55.8 \pm 13$ & $83.77 \pm 1$ \\
\hline $88.5-89.0$ & $26.97-27.13$ & 1037.19 & 7.80 & $53.6 \pm 11$ & $59.38 \pm 1$ \\
\hline $89.0-89.5$ & $27.13-27.28$ & 903.07 & 6.64 & $44.27 \pm 17$ & $51.01 \pm 1$ \\
\hline $89.5-90.0$ & $27.28-27.43$ & 930.01 & 7.08 & $72.71 \pm 10$ & $52.02 \pm 1$ \\
\hline $90.0-90.5$ & $27.43-27.58$ & 961.73 & 9.04 & $30.11 \pm 21$ & $61.86 \pm 1$ \\
\hline
\end{tabular}


TABLE B-I (cont)

\begin{tabular}{|c|c|c|c|c|c|}
\hline \multicolumn{2}{|c|}{ Sample Depth Increment } & \multirow{2}{*}{$\begin{array}{c}\text { Sample } \\
\text { Oven-Dry } \\
\text { Weight } \\
\text { (g) }\end{array}$} & \multirow{2}{*}{$\begin{array}{c}\text { Water } \\
\text { Content } \\
(\%)\end{array}$} & \multirow{2}{*}{$\begin{array}{c}\text { Pu Conc (pCi/g) } \\
\pm \text { Analytical Error } \\
(\%)\end{array}$} & \multirow{2}{*}{$\begin{array}{c}{ }^{241} \text { Am Conc (pCi/g) } \\
\pm \text { Analytical Error } \\
(\%)\end{array}$} \\
\hline$(\mathrm{ft})$ & (m) & & & & \\
\hline $90.5-91.0$ & $27.58-27.74$ & 916.62 & 7.09 & $47.66 \pm 15$ & $64.13 \pm 1$ \\
\hline $91.0-91.5$ & $27.74-27.89$ & 924.31 & 7.38 & $32.32 \pm 21$ & $62.72 \pm 1$ \\
\hline $91.5-92.0$ & $27.89-28.04$ & 912.30 & 7.33 & ND & $74.63 \pm 1$ \\
\hline $92.0-92.5$ & $28.04-28.19$ & 1091.00 & 9.99 & ND & $68.08 \pm 1$ \\
\hline $92.5-93.0$ & $28.19-28.35$ & 910.51 & 7.90 & ND & $74.20 \pm 1$ \\
\hline $93.0-93.5$ & $28.35-28.50$ & 950.88 & 8.01 & $46.50 \pm 13$ & $70.31 \pm 1$ \\
\hline $93.5-94.0$ & $28.50-28.65$ & 946.23 & 7.89 & ND & $78.66 \pm 0$ \\
\hline $94.0-94.5$ & $28.65-28.80$ & 1142.76 & 8.04 & ND & $66.30 \pm 1$ \\
\hline $94.5-95.0$ & $28.80-28.96$ & 928.11 & 7.00 & ND & $67.32 \pm 1$ \\
\hline $95.0-95.5$ & $28.96-29.11$ & 851.81 & 6.87 & ND & $64.39 \pm 1$ \\
\hline $95.5-96.0$ & $29.11-29.26$ & 920.05 & 7.10 & ND & $77.05 \pm 1$ \\
\hline $96.0-96.5$ & $29.26-29.41$ & 961.10 & 10.23 & ND & $66.12 \pm 1$ \\
\hline $96.5-97.0$ & $29.41-29.57$ & 952.10 & 7.69 & ND & $72.93 \pm 1$ \\
\hline $97.0-97.5$ & $29.57-29.72$ & 909.32 & 7.52 & ND & $72.95 \pm 1$ \\
\hline $97.5-98.0$ & $29.72-29.87$ & 942.56 & 7.53 & ND & $78.46 \pm 1$ \\
\hline $98.0-98.5$ & $29.87-30.02$ & 1091.06 & 6.47 & ND & $71.73 \pm 1$ \\
\hline $98.5-99.0$ & $30.02-30.18$ & 813.15 & 7.70 & $28.56 \pm 19$ & $60.71 \pm 1$ \\
\hline $99.0-99.5$ & $30.18-30.33$ & 870.97 & 8.09 & $34.84 \pm 15$ & $62.26 \pm 1$ \\
\hline $99.5-100.0$ & $30.33-30.48$ & 1011.32 & 7.74 & ND & $71.57 \pm 1$ \\
\hline
\end{tabular}


TABLE B-II

SAMPLE WEIGHT, WATER CONTENT, AND PLUTONIUM AND ${ }^{241}$ Am CONCENTRATIONS OF SAMPLES FROM HOLE 2 IN ABSORPTION BED 1

Sample Depth Increment

\begin{tabular}{|c|c|}
\hline (ft) & \\
\hline $2.0-2.5$ & \\
\hline $2.5-3.0$ & \\
\hline $3.0-3.5$ & \\
\hline $3.5-4.0$ & \\
\hline $4.0-4.5$ & \\
\hline $4.5-5.0$ & \\
\hline $5.0-5.5$ & \\
\hline $5.5-6.0$ & \\
\hline $10.5-11.0$ & \\
\hline $11.0-11.5$ & \\
\hline $11.5-12.0$ & \\
\hline $12.0-12.5$ & \\
\hline $12.5-13.0$ & \\
\hline $13.0-13.5$ & \\
\hline $13.5-14.0$ & \\
\hline $14.0-14.5$ & \\
\hline $14.5-15.0$ & \\
\hline $15.0-15.5$ & \\
\hline $15.5-16.0$ & \\
\hline $16.0-16.5$ & \\
\hline $16.5-17.0$ & \\
\hline $17.0-17.5$ & \\
\hline $17.5-18.0$ & \\
\hline $18.0-18.5$ & \\
\hline $18.5-19.0$ & \\
\hline $19.0-19.5$ & \\
\hline $19.5-20.0$ & \\
\hline $20.0-20.5$ & \\
\hline $20.5-21.0$ & \\
\hline $21.0-21.5$ & \\
\hline $21.5-22.0$ & \\
\hline $22.0-22.5$ & \\
\hline $225-23.0$ & \\
\hline $23.0-23.5$ & \\
\hline $23.5-24.0$ & \\
\hline $24.0-24.5$ & \\
\hline $24.5-25.0$ & \\
\hline
\end{tabular}

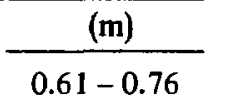

$0.76-0.91$

$0.91-1.07$

$1.07-1.22$

$1.22-1.37$

$1.37-1.52$

$1.52-1.68$

$1.68-1.83$

$3.20-3.35$

$3.35-3.51$

$3.51-3.66$

$3.66-3.81$

$3.81-3.96$

$3.96-4.11$

$4.11-4.27$

$4.27-4.42$

$4.42-4.57$

$4.57-4.72$

$4.72-4.88$

$4.88-5.03$

$5.03-5.18$

$5.18-5.33$

$5.33-5.49$

$5.49-5.64$

$5.64-5.79$

$5.79-5.94$

$5.94-6.10$

$6.10-6.25$

$6.25-6.40$

$6.40-6.55$

$6.55-6.71$

$6.71-6.86$

$6.86-7.01$

$7.01-7.16$

$7.16-7.32$

$7.32-7.47$

$7.47-7.62$
Sample

Oven-Dry

Weight

(g)

710.20

1037.20

1143.89

1052.20

481.10

975.51

1002.90

987.65

720.05

946.17

964.24

954.24

987.01

944.60

940.21

892.80

868.48

910.51

860.06

799.10

1103.70

887.38

883.20

884.70

1070.60

947.90

944.55

946.62

952.01

971.25

920.35

893.17

1084.81

996.10

979.53

879.46

1006.80
Water

Conten

$\frac{(\%)}{16.67}$

16.12

14.32

17.67

14.42

22.37

26.09

27.88

22.41

25.31

25.61

27.01

25.46

27.45

27.57

28.48

25.44

27.01

28.21

b

22.65

23.21

23.48

23.12

13.24

8.68

8.04

8.50

12.74

9.34

8.96

29.33

10.75

9.16

10.36

10.01

9.15
Pu Conc (pCi/g) ${ }^{241} \mathrm{Am}$ Conc $(\mathrm{pCi} / \mathrm{g})$ \pm Analytical Error \pm Analytical Error

(\%)

ND
ND
ND
ND
ND
ND
ND

$562.4 \pm 11$

$469.1 \pm 6$

$91.67 \pm 8$

$36.60 \pm 16$

ND

$32.83 \pm 13$

ND

ND

ND

ND

ND

ND

ND

ND

ND

ND

ND

ND

ND

ND

ND

ND

$36.41 \pm 22$

ND

ND

ND

ND

ND

ND

ND
(\%)

$5.377 \pm 2$
$3.722 \pm 3$
$0.818 \pm 8$
$2.548 \pm 4$
$6.373 \pm 2$
$5.412 \pm 2$
$10.53 \pm 1$

777.;-.0

$79.18 \pm 1$

$29.79 \pm 1$

$26.74 \pm 1$

$21.40 \pm 1$

$27.93 \pm 1$

$36.26 \pm 1$

$55.97 \pm 1$

$64.94 \pm 1$

$76.70 \pm 1$

$85.45 \pm 0$

$88.17 \pm 0$

$141.5 \pm 0$

$143.8 \pm 0$

$50.41 \pm 0$

$26.42 \pm 1$

$35.12 \pm 1$

$152.3 \pm 0$

$67.04 \pm 1$

$49.37 \pm 1$

$34.31 \pm 1$

$42.17 \pm 1$

$1.09 \pm 1$

$11.45 \pm 1$

$10.41 \pm 1$

$14.47 \pm 1$

$4.801 \pm 2$

$3.848 \pm 3$

$3.861 \pm 3$

$7.585 \pm 2$

${ }^{a} \mathrm{ND}$ signifies non-detectable levels of radionuclides at the 3 sigma probability level: $<30 \mathrm{pCi}$ plutonium $/ \mathrm{g}$ and $<0.8$ pCi ${ }^{241} \mathrm{Am} / \mathrm{g}$.

${ }^{6}$ Missing data. 
TABLẸ B-II (cont) -

\begin{tabular}{|c|c|c|c|c|c|}
\hline \multicolumn{2}{|c|}{ Sample Depth Increment } & \multirow{2}{*}{$\begin{array}{c}\text { Sample } \\
\text { Oven-Dry } \\
\text { Weight } \\
\text { (g) } \\
\end{array}$} & \multirow{2}{*}{$\begin{array}{c}\text { Water } \\
\text { Content } \\
(\%) \\
\end{array}$} & \multirow{2}{*}{$\begin{array}{c}\text { Pu Conc (pCi/g) } \\
\pm \text { Analytical Error } \\
(\%)\end{array}$} & \multirow{2}{*}{$\begin{array}{c}{ }^{241} \text { Am Conc (pCi/g) } \\
\pm \text { Analytical Error } \\
\text { (\%) }\end{array}$} \\
\hline$(\mathrm{ft})$ & (m) & & & & \\
\hline $25.0-25.5$ & $7.62-7.77$ & 959.19 & 10.52 & ND & $10.69 \pm 2$ \\
\hline $25.5-26.0$ & $7.77-7.92$ & 893.15 & 10.66 & ND & $15.11 \pm 1$ \\
\hline $26.0-26.5$ & $7.92-8.08$ & 970.50 & 11.23 & ND & $16.71 \pm 1$ \\
\hline $26.5-27.0$ & $8.08-8.23$ & 971.52 & 17.70 & $76.13 \pm 11$ & $85.32 \pm 1$ \\
\hline $27.0-27.5$ & $8.23-8.38$ & 970.86 & 11.07 & ND & $21.55 \pm 1$ \\
\hline $27.5-28.0$ & $8.38-8.53$ & 799.01 & 11.25 & ND & $23.44 \pm 1$ \\
\hline $28.0-28.5$ & $8.53-8.69$ & 875.01 & 13.14 & ND & $29.35 \pm 1$ \\
\hline $28.5-29.0$ & $8.69-8.84$ & 1055.32 & 13.11 & $59.08 \pm 10$ & $50.35 \pm 1$ \\
\hline $29.0-29.51$ & $8.84-8.99$ & 946.90 & 15.09 & $82.46 \pm 9$ & $68.44 \pm 1$ \\
\hline $29.5-30.0$ & $8.99-9.14$ & 1004.00 & 11.18 & ND & $19.04 \pm 1$ \\
\hline $30.0-30.5$ & $9.14-9.30$ & 863.98 & 18.15 & $305.3 \pm 6$ & $88.47 \pm 0$ \\
\hline $30.5-31.0$ & $9.30-9.46$ & 996.92 & 17.51 & $1291 \pm 6$ & $154.4 \pm 1$ \\
\hline $31.0-31.5$ & $9.45-9.60$ & 1005.97 & 17.42 & $3237 \pm 6$ & $243.7 \pm 1$ \\
\hline $31.5-32.0$ & $9.60-9.75$ & 906.60 & 8.36 & $289.9 \pm 6$ & $30.98 \pm 1$ \\
\hline $32.0-32.5$ & $9.75-9.91$ & 885.09 & 7.87 & $243.1 \pm 7$ & $24.90 \pm 1$ \\
\hline $32.5-33.0$ & $9.91-10.06$ & 675.49 & 8.96 & $95.33 \pm 8$ & $28.66 \pm 1$ \\
\hline $33.0-33.5$ & $10.06-10.21$ & 661.40 & 8.69 & $52.11 \pm 10$ & $25.18 \pm 1$ \\
\hline $33.5-34.0$ & $10.21-10.36$ & 774.18 & 8.95 & $40.10 \pm 12$ & $24.18 \pm 1$ \\
\hline $34.0-34.5$ & $10.36-10.52$ & 847.25 & 9.46 & $44.68 \pm 11$ & $37.81 \pm 1$ \\
\hline $34.5-35.0$ & $10.52-10.67$ & 1042.13 & 8.59 & $72.43 \pm 9$ & $33.64 \pm 1$ \\
\hline $35.0-35.5$ & $10.67-10.82$ & 942.70 & 8.87 & $44.47 \pm 12$ & $20.42 \pm 1$ \\
\hline $35.5-36.0$ & $10.82-10.97$ & 900.97 & 8.81 & ND & $16.10 \pm 1$ \\
\hline $36.0-36.5$ & $10.97-11.13$ & 965.44 & 9.52 & ND & $15.01 \pm 1$ \\
\hline $36.5-37.0$ & $11.13-11.28$ & 1014.66 & 9.58 & ND & $15.28 \pm 1$ \\
\hline $37.0-37.5$ & $11.28-11.43$ & 926.12 & 10.08 & ND & $11.91 \pm 1$ \\
\hline $37.5-38.0$ & $11.43-11.58$ & 938.72 & 10.75 & ND & $14.23 \pm 1$ \\
\hline $38.0-38.5$ & $11.58-11.73$ & 909.83 & 10.93 & ND & $14.50 \pm 1$ \\
\hline $38.5-39.0$ & $11.73-11.89$ & 1038.46 & 10.69 & $40.62 \pm 14$ & $18.71 \pm 1$ \\
\hline $39.0-39.5$ & $11.89-12.04$ & 952.00 & 10.97 & $151.5 \pm 7$ & $42.28 \pm 1$ \\
\hline $39.5-40.0$ & $12.04-12.19$ & 921.44 & 9.74 & $50.56 \pm 11$ & $21.88 \pm 1$ \\
\hline $40.0-40.5$ & $12.19-12.34$ & 957.13 & 8.86 & $30.46 \pm 13$ & $21.77 \pm 1$ \\
\hline $40.5-41.0$ & $12.34-12.50$ & 909.60 & 10.25 & $47.32 \pm 11$ & $23.22 \pm 1$ \\
\hline $41.0-41.5$ & $12.50-12.65$ & 879.78 & 10.37 & ND & $23.39 \pm 1$ \\
\hline $41.5-42.0$ & $12.65-12.80$ & 937.26 & 10.76 & $42.99 \pm 12$ & $17.08 \pm 1$ \\
\hline $42.0-42.5$ & $12.80-12.95$ & 913.74 & 11.30 & $45.74 \pm 11$ & $26.08 \pm 1$ \\
\hline $42.5-43.0$ & $12.95-13.11$ & 1017.80 & 8.70 & $40.71 \pm 14$ & $72.50 \pm 1$ \\
\hline $43.0-43.5$ & $13.11-13.26$ & 927.67 & 7.69 & $55.00 \pm 9$ & $20.23 \pm 1$ \\
\hline $43.5-44.0$ & $13.26-13.41$ & 991.00 & 8.00 & $37.14 \pm 11$ & $20.56 \pm 1$ \\
\hline $44.0-44.5$ & $13.41-13.56$ & 900.24 & 8.00 & $41.15 \pm 12$ & $20.01 \pm 1$ \\
\hline $44.5-45.0$ & $13.56-13.72$ & 979.91 & 7.48 & ND & $23.14 \pm 1$ \\
\hline $45.0-45.5$ & $13.72-13.87$ & 929.61 & 8.32 & ND & $18.81 \pm 1$ \\
\hline $45.5-46.0$ & $13.87-14.02$ & 948.62 & 8.47 & ND & $34.77 \pm 1$ \\
\hline $46.0-46.5$ & $14.02-14.17$ & 934.41 & 7.72 & $35.58 \pm 12$ & $24.34 \pm 1$ \\
\hline $46.5-47.0$ & $14.17-14.33$ & 983.20 & 7.01 & $\mathrm{ND}$ & $16.52 \pm 1$ \\
\hline
\end{tabular}


TABLE B-II (cont)

\begin{tabular}{|c|c|c|c|c|c|}
\hline Sample I & Increment & $\begin{array}{c}\text { Sample } \\
\text { Oven-Dry } \\
\text { Weight }\end{array}$ & $\begin{array}{c}\text { Water } \\
\text { Content }\end{array}$ & $\begin{array}{l}\text { Pu Conc (pCi/g) } \\
\pm \text { Analytical Error }\end{array}$ & $\begin{array}{l}{ }^{241} \text { Am Conc }(\mathrm{pCi} / \mathrm{g}) \\
\pm \text { Analytical Error }\end{array}$ \\
\hline (ft) & (m) & (g) & (\%) & & \\
\hline $47.0-47.5$ & $14.33-14.48$ & 966.60 & 7.22 & $33.18 \pm 13$ & $12.94 \pm 1$ \\
\hline $47.5-48.0$ & $14.48-14.63$ & 885.25 & 7.40 & ND & $12.95 \pm 1$ \\
\hline $48.0-48.5$ & $14.63-14.78$ & 926.45 & 7.22 & ND & $13.11 \pm 1$ \\
\hline $48.5-49.0$ & $14.78-14.94$ & 1025.65 & 7.15 & ND & $14.67 \pm 1$ \\
\hline $49.0-49.5$ & $14.94-15.09$ & 916.00 & 7.60 & ND & $13.85 \pm 1$ \\
\hline $49.5-50.0$ & $15.09-15.24$ & 945.60 & 6.62 & ND & $14.40 \pm 1$ \\
\hline $50.0-50.5$ & $15.24-15.39$ & 889.60 & 7.12 & ND & $23.59 \pm 1$ \\
\hline $50.5-51.0$ & $15.39-15.54$ & 991.50 & 6.95 & ND & $27.58 \pm 1$ \\
\hline $51.0-51.5$ & $15.54-15.70$ & 950.37 & 7.55 & ND & $24.54 \pm 1$ \\
\hline $51.5-52.0$ & $15.70-15.85$ & 957.17 & 7.46 & ND & $17.21 \pm 1$ \\
\hline $52.0-52.5$ & $15.85-16.00$ & 919.94 & 7.67 & ND & $14.79 \pm 1$ \\
\hline $52.5-53.0$ & $16.00-16.15$ & 967.46 & 7.64 & ND & $17.41 \pm 1$ \\
\hline $53.0-53.5$ & $16.15-16.31$ & 958.74 & 8.08 & ND & $13.04 \pm 1$ \\
\hline $53.5-54.0$ & $16.31-16.46$ & 951.85 & 8.26 & ND & $12.73 \pm 1$ \\
\hline $54.0-54.5$ & $16.46-16.61$ & 931.10 & 7.55 & ND & $14.27 \pm 1$ \\
\hline $55.5-56.0$ & $16.92-17.07$ & 998.90 & 8.08 & ND & $22.42 \pm 1$ \\
\hline $56.0-56.5$ & $17.07-17.22$ & 907.25 & 8.49 & ND & $20.55 \pm 1$ \\
\hline $56.5-57.0$ & $17.22-17.37$ & 949.63 & 8.62 & ND & $38.55 \pm 1$ \\
\hline $57.0-57.5$ & $17.37-17.53$ & 931.61 & 8.42 & ND & $27.70 \pm 1$ \\
\hline $57.5-58.0$ & $17.53-17.68$ & 895.31 & 8.19 & ND & $26.75 \pm 1$ \\
\hline $58.0-58.5$ & $17.68-17.83$ & 944.82 & 8.81 & ND & $22.45 \pm 1$ \\
\hline $58.5-59.0$ & $17.83-17.98$ & 922.62 & 8.41 & ND & $21.44 \pm 1$ \\
\hline $59.0-59.5$ & $17.98-18.14$ & 961.92 & 9.22 & ND & $31.07 \pm 1$ \\
\hline $59.5-60.0$ & $18.14-18.29$ & 989.02 & 9.13 & ND & $29.90 \pm 1$ \\
\hline $60.0-60.5$ & $18.29-18.44$ & 969.20 & 8.40 & ND & $23.26 \pm 1$ \\
\hline $60.5-61.0$ & $18.44-18.59$ & 960.34 & 9.26 & ND & $24.69 \pm 1$ \\
\hline $61.0-61.5$ & $18.59-18.75$ & 949.64 & 10.01 & ND & $21.58 \pm 1$ \\
\hline $61.5-62.0$ & $18.75-18.90$ & 1043.90 & 9.50 & ND & $25.09 \pm 1$ \\
\hline $62.0-62.5$ & $18.90-19.05$ & 924.50 & 9.39 & ND & $20.04 \pm 1$ \\
\hline $62.5-63.0$ & $19.05-19.20$ & 931.66 & 10.23 & ND & $22.42 \pm 1$ \\
\hline $63.0-63.5$ & $19.20-19.35$ & 943.95 & 9.36 & ND & $21.80 \pm 1$ \\
\hline $63.5-64.0$ & $19.35-19.51$ & 1029.80 & 9.79 & $\mathrm{NL}$ & $24.34 \pm 1$ \\
\hline $64.0-64.5$ & $19.51-19.66$ & 943.40 & 8.41 & ND & $20.74 \pm 1$ \\
\hline $64.5-65.0$ & $19.66-19.81$ & 911.96 & 6.24 & ND & $19.87 \pm 1$ \\
\hline $65.0-65.5$ & $19.81-19.96$ & 910.65 & 4.84 & ND & $19.72 \pm 1$ \\
\hline $65.5-66.0$ & $19.96-20.12$ & 944.10 & 7.91 & ND & $24.96 \pm 1$ \\
\hline $66.0-66.5$ & $20.12-20.27$ & 958.22 & 7.29 & ND & $21.52 \pm 1$ \\
\hline $66.5-67.0$ & $20.27-20.42$ & 855.80 & 7.50 & ND & $19.68 \pm 1$ \\
\hline $67.0-67.5$ & $20.42-20.57$ & 858.97 & 7.82 & ND & $17.92 \pm 1$ \\
\hline $67.5-68.0$ & $20.57-20.73$ & 1026.15 & 7.78 & ND & $23.19 \pm 1$ \\
\hline $68.0-68.5$ & $20.73-20.88$ & 956.30 & 8.02 & ND & $20.44 \pm 1$ \\
\hline $68.5-69.0$ & $20.88-21.03$ & 993.52 & 8.59 & ND & $20.08 \pm 1$ \\
\hline $69.0-69.5$ & $21.03-21.18$ & 100.84 & 8.13 & ND & $22.36 \pm 1$ \\
\hline $69.5-70.0$ & $21.18-21.34$ & 1091.53 & 8.55 & ND & $24.70 \pm 1$ \\
\hline
\end{tabular}


TABLE B.Il (cont)

Sample Depth Increment

\begin{tabular}{c}
\hline (it) \\
\hline $70.0-70.5$ \\
$70.5-71.0$ \\
$71.0-71.5$ \\
$71.5-72.0$ \\
$72.0-72.5$ \\
$72.5-73.0$ \\
$73.0-73.5$ \\
$73.5-74.0$ \\
$74.0-74.5$ \\
$74.5-75.0$ \\
$75.0-75.5$ \\
$75.5-76.0$ \\
$76.0-76.5$ \\
$76.5-77.0$ \\
$77.0-77.5$ \\
$77.5-78.0$ \\
$78.0-78.5$ \\
$78.5-79.0$ \\
$79.0-79.5$ \\
$79.5-80.0$ \\
$80.0-80.5$ \\
$80.5-81.0$ \\
$81.0-81.5$ \\
$81.5-82.0$ \\
$82.0-82.5$ \\
$82.5-83.0$ \\
$83.0-83.5$ \\
$83.5-84.0$ \\
$84.0-84.5$ \\
$84.5-85.0$ \\
$85.0-85.5$ \\
$86.9-87.25$ \\
$87.25-87.75$ \\
$87.75-88.25$ \\
$88.25-88.5$ \\
$88.5-89.0$ \\
$89.0-89.5$ \\
$89.5-90.0$ \\
$90.0-90.5$ \\
$91.0-91.5$ \\
$91.5-92.0$ \\
$92.0-92.5$ \\
$92.5-93.0$ \\
\end{tabular}

\begin{tabular}{c}
$(\mathrm{m})$ \\
\hline $21.34-21.49$ \\
$21.49-21.64$ \\
$21.64-21.79$ \\
$21.79-21.97$ \\
$21.95-22.10$ \\
$22.10-22.25$ \\
$22.25-22.40$
\end{tabular}

$22.40-22.56$

$22.56-22.71$

$22.71-22.86$

$22.86-23.01$

$23.01-23.16$

$23.16-23.32$

$23.32-23.47$

$23.47-23.62$

$23.62-23.77$

$23.77-23.93$

$23.93-24.08$

$24.08-24.23$

$24.23-24.38$

$24.38-24.54$

$24.54-24.69$

$24.69-24.84$

$24.84-24.99$

$24.99-25.15$

$25.15-25.30$

$25.30-25.45$

$25.45-25.60$

$25.60-25.76$

$25.76-25.91$

$25.91-26.06$

$26.49-26.59$

$26.59-26.75$

$26.75-26.90$

$26.90-26.97$

$26.97-27.13$

$27.13-27.28$

$27.28-27.43$

$27.43-27.58$

$27.74-27.89$

$27.89-28.04$

$28.04-28.19$

$28.19-28.35$
Sample
Oven-Dry

Weight

(g)

955.15

958.22

962.03

959.76

950.32

942.90

1011.55

931.00

936.90

952.30

853.62

1087.20

1109.40

971.48

973.58

935.48

921.25

945.75

962.08

1094.27

934.45

986.45

962.33

969.68

958.43

959.30

1009.83

977.12

1002.62

972.22

966.60

1075.13

947.48

994.87

938.88

1051.07

920.53

990.37

953.80

1075.10

981.20

969.55

991.40
Water Pu Canc (pCi/g)

Content \pm A.ralytical Error

(\%)

ND

ND

ND

ND

ND

ND

ND

ND

ND

ND

ND

ND

ND

ND

ND

ND

ND

ND

ND

ND

ND

ND

ND

ND

ND

ND

ND

ND

ND

ND

ND

ND

ND

ND

ND

ND

ND

ND

ND

ND

ND

ND

ND
${ }^{241}$ Am Conc (pCi/g)

\pm Analytical Error

(\%)

$23.38 \pm 1$

$26.22 \pm 1$

$22.02 \pm 1$

$28.30 \pm 1$

$26.32 \pm 1$

$25.53 \pm 1$

$26.59 \pm 1$

$33.94 \pm 1$

$27.10 \pm 1$

$23.11 \pm 1$

$23.93 \pm 1$

$32.88 \pm 1$

$29.74 \pm 1$

$30.64 \pm 1$

$28.80 \pm 1$

$31.11 \pm 1$

$29.50 \pm 1$

$31.00 \pm 1$

$33.12 \pm 1$

$36.42 \pm 1$

$34.18 \pm 1$

$38.27 \pm 1$

$41.93 \pm 1$

$49.90 \pm 1$

$41.62 \pm 1$

$44.68 \pm 1$

$50.62 \pm 1$

$56.89 \pm 1$

$67.85 \pm 1$

$73.74 \pm 1$

$81.89 \pm 1$

$93.81 \pm 1$

$71.78 \pm 1$

$52.63 \pm 1$

$46.70 \pm 1$

$59.02 \pm 1$

$48.81 \pm 1$

$38.78 \pm 1$

$36.02 \pm 1$

$42.21 \pm 1$

$32.77 \pm 1$

$29.44 \pm 1$

$29.44 \pm 1$ 
TABLE B-II (cont)

\begin{tabular}{|c|c|c|c|c|c|}
\hline \multicolumn{2}{|c|}{ Sample Depth Increment } & \multirow{2}{*}{$\begin{array}{c}\text { Sample } \\
\text { Oven-Dry } \\
\text { Weight } \\
\text { (g) }\end{array}$} & \multirow{2}{*}{$\begin{array}{c}\text { Water } \\
\text { Content } \\
(\%)\end{array}$} & \multirow{2}{*}{$\begin{array}{l}\text { Pu Cone }(\mathrm{pCi} / \mathrm{g}) \\
\pm \text { Analytical Error } \\
(\%)\end{array}$} & \multirow{2}{*}{$\begin{array}{c}{ }^{241} \text { Am Conc (pCi/g) } \\
\pm \text { Analytical Error } \\
(\%)\end{array}$} \\
\hline (ft) & (m) & & & & \\
\hline $93.0-93.5$ & $28.35-28.50$ & 994.92 & 6.95 & ND & $33.43 \pm 1$ \\
\hline $93.5-94.0$ & $28.50-28.65$ & 930.22 & 6.74 & ND & $21.88 \pm 1$ \\
\hline $94.0-94.5$ & $28.65-28.80$ & 975.75 & 6.31 & ND & $17.64 \pm 1$ \\
\hline $94.5-95.0$ & $28.80-28.96$ & 929.55 & 5.97 & ND & $12.19 \pm 1$ \\
\hline $95.0-95.5$ & $28.96-29.11$ & 1072.34 & 6.41 & ND & $17.54 \pm 1$ \\
\hline $95.5-96.0$ & $29.11-29.26$ & 964.11 & 6.17 & ND & $8.390 \pm 1$ \\
\hline $96.0-96.5$ & $29.26-29.41$ & 1006.23 & 6.40 & ND & $8.156 \pm 2$ \\
\hline $96.5-97.0$ & $29.41-29.57$ & 966.08 & 6.28 & ND & $7.010 \pm 2$ \\
\hline $97.0-97.5$ & $29.57-29.72$ & 1109.55 & 6.90 & ND & $8.059 \pm 2$ \\
\hline $97.5-98.0$ & $29.72-29.87$ & 967.49 & 6.67 & ND & $7.564 \pm 2$ \\
\hline $98.0-98.5$ & $29.87-30.02$ & 946.65 & 6.99 & ND & $8.505 \pm 2$ \\
\hline $98.5-99.0$ & $30.02-30.18$ & 985.99 & 7.28 & ND & $8.883 \pm 2$ \\
\hline $99.0-99.5$ & $30.18-30.33$ & 514.09 & 3.53 & ND & $60.6 E \pm 1$ \\
\hline $99.5-100.0$ & $30.33-30.48$ & 877.88 & 6.65 & ND & $7.994 \pm 1$ \\
\hline $100.0-100.5$ & $30.48-30.63$ & 974.30 & 6.90 & ND & $8.415 \pm 2$ \\
\hline $100.5-101.0$ & $30.63-30.78$ & 1000.80 & 7.27 & ND & $8.743 \pm 2$ \\
\hline
\end{tabular}


SAMPLE WEIGHT, WATER CONTENT, AND PLUTONIUM AND ${ }^{241}$ Am CONCENTRATIONS OF SAMPLES FROM HOLE 1 IN ABSORPTION BED 2

Sample Depth Increment

\begin{tabular}{ccc}
\hline (ft) & & $(\mathrm{m})$ \\
\cline { 1 - 1 } $3.0-4.0$ & & $0.91-1.22$ \\
$7.0-7.5$ & & $2.13-2.29$ \\
$7.5-8.0$ & & $2.29-2.44$ \\
$8.0-8.5$ & & $2.44-2.59$ \\
$8.5-9.0$ & & $2.59-2.74$ \\
$9.0-9.5$ & & $2.74-2.90$ \\
$9.5-10.0$ & & $2.90-3.05$ \\
$10.0-10.5$ & & $3.05-3.20$ \\
$10.5-11.0$ & & $3.20-3.35$ \\
$11.0-11.5$ & & $3.35-3.51$ \\
$11.5-12.0$ & & $3.51-3.66$ \\
$12.0-12.5$ & & $3.66-3.81$ \\
$12.5-13.0$ & & $3.81-3.96$ \\
$13.0-13.5$ & & $3.96-4.11$ \\
$13.5-14.0$ & & $4.11-4.27$ \\
$14.0-14.5$ & & $4.27-4.42$ \\
$14.5-15.0$ & & $4.42-4.57$ \\
$15.0-15.5$ & & $4.57-4.72$ \\
$15.5-16.0$ & & $4.72-4.88$ \\
$16.0-16.5$ & & $4.88-5.03$ \\
$17.5-18.0$ & & $5.33-5.49$ \\
$18.0-18.5$ & & $5.49-5.64$ \\
$18.5-19.0$ & & $5.64-5.79$ \\
$19.0-19.5$ & & $5.79-5.94$ \\
$19.5-20.0$ & & $5.94-6.10$ \\
$20.0-205$ & & $6.10-6.25$ \\
$20.5-21.0$ & & $6.25-6.40$ \\
$21.0-21.5$ & & $6.40-6.55$ \\
$21.5-22.0$ & & $6.55-6.71$ \\
$22.0-22.5$ & & $6.71-6.86$ \\
$22.5-23.0$ & & $6.86-7.01$ \\
$23.0-23.5$ & & $7.01-7.16$ \\
$23.5-24.0$ & & $7.16-7.32$ \\
$24.0-24.5$ & & $7.32-7.47$ \\
$24.5-25.0$ & & $7.47-7.62$ \\
$25.0-25.5$ & & $7.62-7.77$ \\
$25.5-26.0$ & & $7.77-7.92$ \\
$26.0-26.5$ & & $7.92-8.08$ \\
& &
\end{tabular}

Sample

Oven-Dry

Weight

(g)

1199.99

a

923.20

968.20

946.00

766.09

968.72

947.76

930.44

914.13

982.10

993.36

1006.86

949.88

965.54

872.54

1003.46

918.99

935.41

960.09

997.77

985.91

954.04

970.28

990.60

993.32

978.87

969.20

1024.35

971.42

921.66

900.52

933.62

944.11

920.20

670.63

1037.45

1021.08
Water Pu Conc (pCi/g)

Content \pm Analytical Error

(\%)

$12156 \pm 6$

$7903 \pm 6$

$16656 \pm 5$

$15702 \pm 5$

$15744 \pm 5$

$2923 \pm 8$

$2270 \pm 8$

$321.9 \pm 10$

$341.9 \pm 10$

$625.2 \pm 8$

$2063 \pm 8$

$355.4 \pm 10$

$263.8 \pm 9$

$\mathrm{ND}^{\mathrm{b}}$

$200.5 \pm 17$

ND

$256.9 \pm 14$

ND

ND

ND

ND

ND

ND

ND

ND

ND

$158.2 \pm 9$

$29.41 \pm 36$

ND

ND

ND

ND

ND

ND

ND

ND

ND

ND
${ }^{241} \mathrm{Am}$ Conc (pCi/g)

\pm Analytical Error

(\%)

$1548 \pm 1$

$615.1 \pm 1$

$1687 \pm 1$

$3481 \pm 1$

$3240 \pm 1$

$1912 \pm 1$

$520.7 \pm 1$

$303.1 \pm 1$

$303.8 \pm 1$

$425.7 \pm 1$

$1316 \pm 1$

$305.8 \pm 1$

$192.0 \pm 1$

$337.1 \pm 1$

$383.0 \pm 1$

$332.0 \pm 1$

$422.8 \pm 1$

$903.4 \pm 1$

$574.3 \pm 1$

$132.6 \pm 1$

$124.1 \pm 1$

$124.3 \pm 1$

$87.30 \pm 1$

$90.61 \pm 1$

$80.76 \pm 1$

$121.5 \pm 1$

$52.27 \pm 1$

$20.68 \pm 2$

$21.22 \pm 2$

$52.96 \pm 1$

$12.23 \pm 2$

$19.00 \pm 2$

$22.49 \pm 2$

$29.59 \pm 2$

$41.14 \pm 1$

$17.34 \pm 2$

$6.444 \pm 3$

$20.00 \pm 1$

'Missing data.

${ }^{b} \mathrm{ND}$ signifies nondetectable levels of radionuclides at the 3-sigma probability level: $<30 \mathrm{pCi}$ plutonium/g and $<0.8 \mathrm{pCi}{ }^{241} \mathrm{Am} / \mathrm{g}$. 
TABLE B-III (cont)

Sample Depth Increinent

\section{(ft)}$$
26
$$

$27.0-27.5$

$27.5-28.0$

$28.0-28.5$

$28.5-29.0$

$29.0-29.5$

$29.5-30.0$

$30.0-30.5$

$30.5-31.0$

$31.0-31.5$

$31.5-32.0$

$32.0-32.5$

$32.5-33.0$

$33.0-33.5$

33.5. -34.0

$34.0-34.8$

$34.8-35.5$

$35.5-36.0$

$36.0-36.5$

$36.5-37.0$

$37.0-37.5$

$37.5-38.0$

$38.0-38.5$

$38.5-39.0$

$39.0-39.5$

$39.5-40.0$

$40.0-40.5$

$40.5-41.0$

$41.0-41.5$

$41.5-42.0$

$42.0-42.5$

$42.5-43.0$

$43.0-43.5$

$43.5-44.0$

$44.0-44.5$

$44.5-45.0$

$45.0-45.5$

$45.5-46.0$

$46.5-47.0$

$47.0-47.5$

$47.5-48.0$

$48.0-48.5$

$48.5-49.0$ (m)

$8.08-8.23$

$8.23-8.38$

$8.38-8.53$

$8.53-8.69$

$8.69-8.84$

$8.84-8.99$

$8.99-9.14$

$9.14-9.30$

$9.30-9.45$

$9.45-9.60$

$9.60-9.75$

$9.75-9.91$

$9.91-10.06$

$10.06-10.21$

$10.21-10.36$

$10.36-10.61$

$10.61-10.82$

$10.82-10.97$

$10.97-11.13$

$11.13-11.28$

$11.28-11.43$

$11.43-11.58$

$11.58-11.73$

$11.73-11.89$

$11.89-12.04$

$12.04-12.19$

$12.19-12.34$

$12.34-12.50$

$12.50-12.65$

$12.65-12.80$

$12.80-12.95$

$12.95-13.11$

$13.11-13.26$

$13.26-13.41$

$13.41-13.56$

$13.56-13.72$

$13.72-13.87$

$13.87-14.02$

$14.17-14.33$

$14.33-14.48$

$14.48-14.63$

$14.63-14.78$

$14.78-14.94$
Sample

Oven-Dry Water Pu Conc (pCi/g) ${ }^{241} \mathrm{Am}$ Conc $(\mathrm{pCi} / \mathrm{g})$

Weight

(8)

1013.45

1026.80

1048.02

915.88

936.87

990.30

885.35

908.57

962.38

920.58

854.02

951.89

959.59

979.56

989.32

963.36

1066.40

759.32

930.15

1014.16

700.69

969.69

961.26

970.74

987.77

961.64

928.42

1028.16

1021.36

1119.70

974.83

980.78

941.24

948.49

839.24

969.98

1013.90

927.64

993.29

904.52

999.25

910.70

969.42 Content \pm Aralytical Error

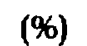

8.89

7.57

8.07

7.58

7.86

7.98

8.14

8.93

9.54

10.43

12.406

15.37

16.15

12.52

13.39

13.19

7.08

9.06

6.48

7.00

11.01

14.51

13.84

8.79

6.71

7.38

6.31

7.79

10.69

9.02

6.63

6.09

6.63

6.79

7.74

8.20

8.28

8.63

9.13

9.13

8.72

8.24

8.30

(\%)

ND

ND

ND

ND

ND

ND

ND

ND

ND

ND

ND

ND

ND

ND

ND

ND

ND

ND

ND

ND

ND

ND

ND

ND

ND

ND

ND

ND

ND

ND

ND

ND

ND

ND

ND

ND

ND

ND

ND

ND

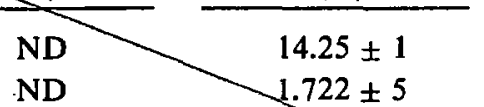

ND $\quad 9.603 \pm 2$
$19.47 \pm 1$ $30.44 \pm 1$ $46.37 \pm 1$

$74.81 \pm 1$

$79.22 \pm 1$

$179.4 \pm 1$

$371.6 \pm 0$

$692.6 \pm 0$

$1310 \pm 0$

$1128 \pm 0$

$693.0 \pm 0$

$2349 \pm 0$

i $570 \pm 0$

$203.5 \pm 0$

$563.4 \pm 0$

$32.77 \pm 1$

$24.21 \pm 1$

$65.39 \pm 1$

$61.18 \pm 1$

$0.493 \pm 15$

ND

ND

$20.13 \pm 1$

ND

ND

ND

$11.54 \pm 1$

$3.715 \pm 3$

$1.381 \pm 6$

$2.377 \pm 4$

$1.401 \pm 6$

ND

ND

ND

ND

ND

ND

ND

ND

ND 
TABLE B-III (cont)

\begin{tabular}{|c|c|c|c|c|c|}
\hline \multicolumn{2}{|c|}{ Sample Depth Increment } & \multirow{2}{*}{$\begin{array}{c}\text { Oven-Dry } \\
\text { Weight } \\
\text { (g) } \\
\end{array}$} & \multirow{2}{*}{$\begin{array}{c}\text { Water } \\
\text { Content } \\
(\%) \\
\end{array}$} & \multirow{2}{*}{$\begin{array}{c}\text { Pu Cone (pCi/g) } \\
\pm \text { Analytical Error } \\
(\%) \\
\end{array}$} & \multirow{2}{*}{$\begin{array}{c}{ }^{241} \text { Am Conc }(\mathrm{pCi} / \mathrm{g}) \\
\pm \text { Analytical Error } \\
(\%)\end{array}$} \\
\hline (ft) & (m) & & & & \\
\hline $49.0-49.5$ & $14.94-15.09$ & 995.80 & 8.44 & ND & ND \\
\hline $49.5-50.0$ & $15.09-15.24$ & 944.49 & 9.00 & ND & ND \\
\hline $50.0-50.5$ & $15.24-15.39$ & 812.91 & 6.18 & ND & ND \\
\hline $50.5-51.0$ & $15.39-15.54$ & 919.22 & 7.35 & ND & ND \\
\hline $51.0-51.5$ & $15.54-15.70$ & 866.07 & 9.95 & ND & ND \\
\hline $51.5-52.0$ & $15.70-15.85$ & 1041.39 & 16.97 & - & - \\
\hline $52.0-52.5$ & $15.85-16.00$ & 893.99 & 14.17 & ND & ND \\
\hline $53.5-54.0$ & $16.31-16.46$ & 988.89 & 6.84 & - & - \\
\hline $54.0-54.5$ & $16.46-16.61$ & 964.00 & 6.75 & ND & ND \\
\hline $54.5-55.0$ & $16.61-16.76$ & 983.60 & 6.90 & - & - \\
\hline $55.0-55.5$ & $16.76-16.92$ & 933.26 & 6.65 & ND & ND \\
\hline $55.5-56.0$ & $16.92-17.07$ & 979.45 & 6.54 & - & - \\
\hline $56.0-56.5$ & $17.07-17.22$ & 939.82 & 6.78 & ND & ND \\
\hline $56.5-57.0$ & $17.22-17.37$ & 1011.19 & 7.71 & - & - \\
\hline $57.0-57.5$ & $17.37-17.53$ & 646.85 & 6.33 & ND & ND \\
\hline $57.5-58.0$ & $17.53-17.68$ & 928.62 & 9.09 & - & - \\
\hline $58.0-58.5$ & $17.68-17.83$ & 966,16 & 6.74 & ND & ND \\
\hline $58.5-59.0$ & $17.83-17.98$ & 995.63 & 7.16 & - & - \\
\hline $59.0-59.5$ & $17.98-18.14$ & 977.10 & 7.07 & - & - \\
\hline $59.5-60.0$ & $18.14-18.29$ & 906.72 & 9.64 & ND & ND \\
\hline $60.0-60.5$ & $18.29-18.44$ & 967.30 & 7.89 & ND & ND \\
\hline $60.5-6.10$ & $18.44-18.59$ & 978.12 & 7.57 & - & - \\
\hline $61.0-61.5$ & $18.59-18.75$ & 943.21 & 7.74 & ND & ND \\
\hline $61.5-62.0$ & $18.75-18.90$ & 1002.39 & 7.51 & - & - \\
\hline $62.0-62.5$ & $18.90-19.05$ & 962.80 & 7.47 & ND & ND \\
\hline $62.5-63.0$ & $19.05-19.20$ & 982.55 & 7.31 & - & - \\
\hline $63.0-63.5$ & $19.20-19.35$ & 922.05 & 7.14 & ND & ND \\
\hline $63.5-64.0$ & $19.35-19.51$ & 937.49 & 10.64 & - & - \\
\hline $64.0-64.5$ & $19.51-19.66$ & 936.45 & 7.84 & ND & ND \\
\hline $64.5-65.0$ & $19.66-19.81$ & 939.20 & 7.09 & - & - \\
\hline $65.0-65.5$ & $19.81-19.56$ & 959.88 & 5.10 & ND & ND \\
\hline $65.6-66.0$ & $19.96-20.12$ & 940.89 & 5.41 & - & - \\
\hline $66.0-66.5$ & $20.12-20.27$ & 962.40 & 5.40 & ND & ND \\
\hline $66.5-67.0$ & $20.27-20.42$ & 944.21 & 5.61 & - & - \\
\hline $67.0-67.5$ & $20.42-20.57$ & 941.30 & 5.87 & ND & ND \\
\hline $67.5-68.0$ & $20.57-20.73$ & 890.03 & 6.31 & - & - \\
\hline $68.0-68.5$ & $20.73-20.88$ & 978.02 & 6.32 & ND & ND \\
\hline $68.5-69.0$ & $20.88-21.03$ & 961.90 & 6.72 & - & - \\
\hline $69.0-69.5$ & $21.03-21: 18$ & 858.80 & 6.45 & ND & ND \\
\hline $69.5-70.0$ & $21.18-21.34$ & 846.80 & 7.13 & - & - \\
\hline $70.0-70.5$ & $21.34-21.49$ & 966.22 & 6.25 & ND & ND \\
\hline $70.5-71.0$ & $21.49-21.64$ & 943.11 & 6.49 & - & - \\
\hline $71.0-71.5$ & $21.64-21.79$ & 1104.08 & 6.33 & ND & ND \\
\hline
\end{tabular}


TABLE B-III (cont)

Sample Depth Increment

\section{(ft)}

$$
\begin{aligned}
& 72 \\
& 72 \\
& 73.0 \\
& 73 . \\
& 74 .
\end{aligned}
$$$$
74.0-74.5
$$$$
74.5-75.0
$$$$
75.0-75.5
$$$$
75.5-76.0
$$$$
76.0-76.5
$$$$
76.5-77.0
$$$$
77.0-77.5
$$$$
77.5-78.0
$$$$
78.0-78.5
$$$$
78.5-79.0
$$$$
79.0-79.5
$$$$
79.5-80.0
$$$$
81.0-81.5
$$$$
81.5-82.0
$$$$
82.0-82.5
$$$$
82.5-83.0
$$$$
83.0-83.5
$$$$
83.5-84.0
$$$$
84.0-84.5
$$$$
84.5-85.0
$$$$
85.0-85.5
$$$$
85.5-86.0
$$$$
86.0-86.5
$$$$
86.5-87.0
$$$$
87.0-87.5
$$$$
87.5-88.0
$$$$
88.0-885
$$$$
88.5-89.0
$$$$
89.0-89.5
$$$$
89.5-90.0
$$$$
90.0-90.5
$$$$
90.5-91.0
$$$$
91.0-91.5
$$$$
91.5-92.0
$$$$
92.0-92.5
$$$$
93.0-93.5
$$$$
93.5-94.0
$$$$
94.0-94.5
$$$$
94.5-95.0
$$

(m)

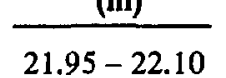

$22.10-22.25$

$22.25-22.40$

$22.40-22.56$

$22.56-22.71$

$22.71-22.86$

$22.86-23.01$

$23.01-23.16$

$23.16-23.32$

$23.32-23.47$

$23.47-23.62$

$23.62-23.77$

$23.77-23.93$

$23.93-24.08$

$24.08-24.23$

$24.23-24.38$

$24.69-24.84$

$24.84-24.99$

$24.99-25.15$

$25.15-25.30$

$25.30-25.45$

$25.45-25.60$

$25.60-25.76$

$25.76-25.91$

$25.91-26.06$

$26.06-26.21$

$26.21-26.37$

$26.37-26.52$

$26.52-26.67$

$26.67-26.82$

$26.82-26.97$

$26.97-27.13$

$27.13-27.28$

$27.28-28.43$

$27.43-27.58$

$27.58-27.74$

$27.74-27.89$

$27.89-28.04$

$28.04-28.19$

$28.35-28.50$

$28.50-28.65$

$28.65-28.80$

$28.80-28.96$

\section{Sample}

Oven-Dry

Weight

(B)

957.45

850.95

854.02

581.04

791.42

941.50

957.03

1044.31

881.70

961.31

963.13

965.29

921.66

875.44

999.87

1060.15

1053.30

982.30

1022.58

865.41

977.69

935.46

994.79

933.11

969.40

970.35

1129.47

867.95

1000.56

971.61

950.70

934.00

954.92

895.27

1102.17

935.98

947.89

956.04

648.00

810.90

960.68

972.24

911.52
Water Pu Conc (pCi/g) ${ }^{241} \mathrm{Am} \mathrm{Conc}(\mathrm{pCi} / \mathrm{g})$

Content \pm Analytical Error \pm Analytical Error

6.47

6.10

6.70

6.37

6.04

6.14

6.18

6.30

7.11

6.07

6.25

6.02

6.52

6.86

6.64

6.71

6.08

6.14

5.35

8.39

5.83

6.52

5.48

5.38

5.74

5.63

5.66

8.50

5.49

5.49

5.30

5.17

5.22

5.42

5.30

5.55

5.40

5.35

5.41

8.76

5.16

5.64

5.55
(\%)

(\%)

ND ND

ND

ND

-

ND

-

ND

ND

ND

ND

ND

ND

-

ND

ND

-

ND

$-$

$-$

ND

-

-

ND

-

ND

ND

-

ND

ND

ND

-

ND

ND

ND

ND

-

ND

-

ND

-

ND

ND

-

ND

ND

$-$

ND 


\section{TABLE B-III (cont)}

\begin{tabular}{|c|c|c|c|c|c|}
\hline \multicolumn{2}{|c|}{ Sample Depth Increment } & \multirow{2}{*}{$\begin{array}{c}\text { Sample } \\
\text { Oven-Dry } \\
\text { Weight } \\
\text { (g) }\end{array}$} & \multirow{2}{*}{$\begin{array}{l}\text { Water } \\
\text {-ontent } \\
(\%) \\
\end{array}$} & \multirow{2}{*}{$\begin{array}{c}\text { Pu Conc (pCi/g) } \\
\pm \text { Analytical Error } \\
(\%)\end{array}$} & \multirow{2}{*}{$\begin{array}{c}{ }^{241} \text { Am Conc (pCi/g) } \\
\pm \text { Analytical Error } \\
(\%)\end{array}$} \\
\hline (ft) & (m) & & & & \\
\hline $95.0-95.5$ & $28.96-29.11$ & 824.47 & 5.48 & ND & ND \\
\hline $95.5-96.0$ & $29.11-29.26$ & 997.33 & 5.66 & - & - \\
\hline $96.0-96.5$ & $29.26-29.41$ & 949.10 & 5.73 & ND & ND \\
\hline $96.5-97.0$ & $29.41-29.57$ & 1015.94 & 5.93 & - & - \\
\hline $97.0-97.5$ & $29.57-29.72$ & 792.89 & 6.87 & ND & ND \\
\hline $97.5-98.0$ & $29.72-29.87$ & 963.27 & 5.65 & - & - \\
\hline $98.0-98.5$ & $29.87-30.02$ & 982.57 & 5.93 & ND & ND \\
\hline $98.5-99.0$ & $30.02-30.18$ & 936.05 & 5.07 & - & - \\
\hline $99.0-99.5$ & $30.18-30.33$ & 920.31 & $6.60^{\circ}$ & ND & ND \\
\hline $99.5-100.0$ & $30.33-30.48$ & 939.56 & 5.92 & - & - \\
\hline $100.0-100.5$ & $30.48-30.63$ & 986.41 & 5.52 & ND & ND \\
\hline $100.5-101.0$ & $30.63-30.78$ & 598.75 & 5.78 & - & - \\
\hline
\end{tabular}




\section{TABLE B-IV}

SAMPLE WEIGHT, WATER CONTENT, AND PLUTONIUM AND ${ }^{241}$ Am CONCENTRATIONS OF SAMPLES FROM HOLE 2 IN ABSORPTION BED 2

\begin{tabular}{|c|c|c|c|c|c|}
\hline \multicolumn{2}{|c|}{ Sample Erepth In:rement } & \multirow{2}{*}{$\begin{array}{c}\text { Sample } \\
\text { Oven-Dry } \\
\text { Weight } \\
\text { (g) } \\
\end{array}$} & \multirow{2}{*}{$\begin{array}{c}\text { Water } \\
\text { Content } \\
(\%) \\
\end{array}$} & \multirow{2}{*}{$\begin{array}{c}\text { Pu Conc (pCi/g) } \\
\pm \text { Analytical Error } \\
(\%)\end{array}$} & \multirow{2}{*}{$\begin{array}{c}{ }^{241} \mathrm{Am} \text { Conc }(\mathrm{pCi} / \mathrm{g}) \\
\pm \text { Analytical Error } \\
(\%) \\
\end{array}$} \\
\hline$(\mathrm{ft})$ & (m) & & & & \\
\hline $2.5-3.0$ & $0.76-0.91$ & 527.92 & 10.26 & $988.4 \pm 7$ & $382.1 \pm 1$ \\
\hline $3.0-3.5$ & $0.91-1.07$ & 1101.81 & 6.24 & $2435 \pm 6$ & $457.0 \pm 1$ \\
\hline $3.5-4.0$ & $1.07-1.22$ & 1152.10 & 9.79 & $300.6 \pm 6$ & $71.69 \pm 1$ \\
\hline $4.0-4.5$ & $1.22-1.37$ & 1016.14 & 6.58 & $\mathrm{ND}^{\mathrm{a}}$ & $957.1 \pm 0$ \\
\hline $8.0-8.5$ & $2.44-2.59$ & 869.97 & 9.01 & $11479 \pm 5$ & $1076 \pm 1$ \\
\hline $8.5-9.0$ & $2.59-2.74$ & 976.87 & 9.26 & $7137 \pm 6$ & $422.1 \pm 1$ \\
\hline $9.0-9.5$ & $2.74-2.90$ & 916.50 & 9.07 & $7579 \pm 6$ & $496.0 \pm 1$ \\
\hline $9.5-10.0$ & $2.90-3.05$ & 997.69 & 9.13 & $3788 \pm 5$ & $349.8 \pm 1$ \\
\hline $10.0-10.5$ & $3.05-3.20$ & 919.20 & 10.54 & $3880 \pm 6$ & $1021 \pm 1$ \\
\hline $10.5-11.0$ & $3.20-3.35$ & 865.11 & 20.70 & $1572 \pm 14$ & $2887 \pm 1$ \\
\hline $11.0-11.5$ & $3.35-3.51$ & 939.01 & 14.10 & ND & $1520 \pm 1$ \\
\hline $11.5-12.0$ & $3.51-3.66$ & 1122.90 & 11.71 & ND & $680 \pm 0$ \\
\hline $12.0-12.5$ & $3.66-3.81$ & 895.38 & 11.22 & ND & $1155 \pm 1$ \\
\hline $12.5-13.0$ & $3.81-3.96$ & 953.00 & 12.32 & ND & $1032 \pm 1$ \\
\hline $13.0-13.5$ & $3.96-4.11$ & 852.53 & 8.14 & ND & $231.6 \pm 0$ \\
\hline $13.5-14.0$ & $4.11-4.27$ & 1041.64 & 8.19 & ND & $268.7 \pm 0$ \\
\hline $14.0-14.5$ & $4.27-4.42$ & 952.33 & 9.40 & $218.7 \pm 20$ & $596.3 \pm 1$ \\
\hline $14.5-15.0$ & $4.42-4.57$ & 984.24 & 8.38 & ND & $319.4 \pm 0$ \\
\hline $15.0-15.5$ & $4.57-4.72$ & 903.30 & 11.50 & ND & $1034 \pm 0$ \\
\hline $15.5-16.0$ & $4.72-4.88$ & 1061.98 & 16.54 & ND & $1031 \pm 1$ \\
\hline $16.0-16.5$ & $4.88-5.03$ & 1036.82 & 14.41 & ND & $666.7 \pm 0$ \\
\hline $16.5-17.0$ & $5.03-5.18$ & 805.07 & 8.41 & $284.2 \pm 17$ & $511.3 \pm 0$ \\
\hline $17.0-17.5$ & $5.18-5.33$ & 871.17 & 6.92 & ND & $187.7 \pm 0$ \\
\hline $17.5-18.0$ & $5.33-5.49$ & $1075.3^{2} 4$ & 5.94 & ND & $109.1 \pm 0$ \\
\hline $18.0-18.5$ & $5.49-5.64$ & 860.80 & 6.41 & ND & $117.0 \pm 0$ \\
\hline $38.5-19.0$ & $5.64-5.79$ & 969.84 & 6.25 & ND & $89.82 \pm 0$ \\
\hline $19.0-19.5$ & $5.79-5.94$ & 951.16 & 6.25 & ND & $90.55 \pm 0$ \\
\hline $19.5-20.0$ & $5.94-6.10$ & 877.51 & 6.37 & ND & $85.41 \pm 0$ \\
\hline $20.0-20.5$ & $6.10-6.25$ & 905.14 & 6.19 & ND & $55.62 \pm 1$ \\
\hline $20.5-21.0$ & $6.25-6.40$ & 979.62 & 5.95 & ND & $43.65 \pm 1$ \\
\hline $21.0-21.5$ & $6.40-6.55$ & 968.31 & 6.43 & ND. & $32.14 \pm 1$ \\
\hline $21.5-22.0$ & $6.55-6.71$ & 1107.74 & 5.76 & ND & $19.97 \pm 1$ \\
\hline $22.0-22.5$ & $6.71-6.86$ & 994.64 & 6.90 & ND & $23.67 \pm 1$ \\
\hline $22.5-23.0$ & $6.86-7.01$ & 929.73 & 6.81 & ND & $17.32 \pm 1$ \\
\hline $23.0-23.5$ & $7.01-7.16$ & 914.28 & 6.74 & ND & $18.98 \pm 1$ \\
\hline $23.5-24.0$ & $7.16-7.32$ & 1083.79 & 7.40 & ND & $18.76 \pm 1$ \\
\hline $24.0-24.5$ & $7.32-7.47$ & 896.51 & 7.61 & ND & $45.12 \pm 1$ \\
\hline $24.5-25.0$ & $7.47-7.62$ & 860.57 & 10.58 & ND & $19.50 \pm 1$ \\
\hline
\end{tabular}

${ }^{\mathrm{a}} \mathrm{ND}$ signifies non-detectable levels of radionuclides at the 3 sigma probaioility level: $<30 \mathrm{pCi}$ plutonium/g and $<0.8$ $\mathrm{pCi}{ }^{241} \mathrm{Am} / \mathrm{g}$. 
TABLE B-IV (cont)

Sample Depth Increment

\begin{tabular}{c}
\hline$(\mathrm{ft})$ \\
\hline $25.0-25.5$ \\
$25.5-26.0$ \\
$26.0-26.5$ \\
$26.5-27.0$ \\
$27.0-27.5$ \\
$27.5-28.0$ \\
$28.0-28.5$ \\
$28.5-29.0$ \\
$29.0-29.5$ \\
$29.5-30.0$ \\
$30.0-30.5$ \\
$30.5-31.0$ \\
$31.0-31.5$ \\
$31.5-32.0$ \\
$22.0-32.5$ \\
$32.5-33.0$ \\
$33.0-33.5$ \\
$33.5-34.0$ \\
$34.0-34.5$ \\
$34.5-35.0$ \\
$35.0-35.5$ \\
$35.5-36.0$ \\
$36.0-36.5$ \\
$36.5-37.0$ \\
$37.0-37.5$ \\
$37.5-38.0$ \\
$38.0-38.5$ \\
$38.5-39.0$ \\
$39.0-39.5$ \\
$39.5-40.0$ \\
$40.0-40.5$ \\
$40.5-41.0$ \\
$41.0-41.5$ \\
$41.5-42.0$ \\
$42.0-42.5$ \\
$42.5-43.0$ \\
$43.0-43.5$ \\
$43.5-44.0$ \\
$44.5-45.0$ \\
$45.0-45.5$ \\
$45.5-46.0$ \\
$46.0-46.5$ \\
$46.5-47.0$ \\
\end{tabular}

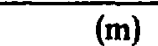

$7.62-7.77$

$7.77-7.92$

$7.92-8.08$

$8.08-8.23$

$8.23-8.38$

$8.38-8.53$

$8.53-8.69$

$8.69-8.84$

$8.84-8.99$

$8.99-9.14$

$9.14-9.30$

$9.30-9.45$

$9.45-9.60$

$9.60-9.75$

$9.75-9.91$

$9.91-10.06$

$10.06-10.21$

$10.21-10.36$

$10.36-10.52$

$10.52-10.67$

$10.67-10.82$

$10.82-10.97$

$10.97-11.13$

$11.13-11.28$

$11.28-11.43$

$11.43-11.58$

$11.58-11.73$

$11.73-11.89$

$11.89-12.04$

$12.04-12.19$

$12.19-12.34$

$12.34-12.50$

$12.50-12.65$

$12.65-12.80$

$12.80-12.95$

$12.95-13.11$

$13.11-13.26$

$13.26-13.41$

$13.56-13.72$

$13.72-13.87$

$13.87-14.02$

$14.02-14.71$

$14.17-14.33$
Sample

Oven-Dry

Weight

(g)

965.71

1052.17

963.54

935.66

941.71

935.66

997.98

919.36

905.35

871.95

842.76

893.92

901.54

934.01

863.22

895.02

902.92

887.98

850.28

915.04

893.99

881.22

806.83

895.71

881.79

838.04

900.91

930.00

847.85

951.29

519.25

875.51

944.34

936.60

915.43

920.66

915.50

916.08

911.30

954.83

928.38

907.89

1019.81
Water

Conten

$(\%)$

13.79

8.69

12.50

7.36

7.63

7.38

6.56

6.87

6.85

8.17

13.67

13.76

7.17

6.89

8.28

6.85

6.27

5.21

6.66

7.46

7.29

5.88

5.48

5.86

6.47

6.41

5.90

6.23

6.97

6.13

3.31

4.81

5.59

3.87

4.13

3.12

2.80

5.06

5.15

4.26

4.17

3.79

5.08
Pu Conc (pCi/g) ${ }^{241}$ Am Conc $(\mathrm{pCi} / \mathrm{g})$

\pm Analytical Error \pm Analytica! Error

(\%)

ND

ND

ND

ND

ND

ND

ND

ND

ND

ND

ND

ND

ND

ND

ND

ND

$-$

ND

ND

ND

ND

ND

ND

ND

ND

ND

ND

ND

ND

ND

ND

ND

ND

ND

ND

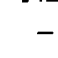

ND

ND

-

ND
(\%)

$7.106 \pm 2$

ND

$2.320 \pm 5$

ND

ND

$2.741 \pm 4$

$23.20 \pm 1$

$93.67 \pm 0$

$20.48 \pm 1$

$7.953 \pm 2$

$5.888 \pm 2$

ND

ND

ND

$1.801 \pm 5$

ND

ND

$8.851 \pm 2$

$36.03 \pm 1$

$18.19 \pm 1$

$1 \hat{3} .14 \pm 1$

$11.27 \pm 1$

$8.561 \pm 2$

$12.68 \pm 1$

$19.07 \pm 1$

$22.41 \pm 1$

$26.31 \pm 1$

$93.61 \pm 1$

$54.95 \pm 1$

$21.26 \pm 1$

$7.760 \pm 2$

$1.765 \pm 5$

$0.976 \pm 10$

$-$

ND

ND

ND

-

ND 
TABLE B-IV (cont)

Sample Depth Increment

\begin{tabular}{|c|c|}
\hline (ft) & (m) \\
\hline $47.0-47.5$ & $14.33-14.4$ \\
\hline $47.5-48.0$ & $14.48-14.63$ \\
\hline $48.0-48.5$ & $14.63-14.78$ \\
\hline $48.5-49.0$ & $14.78-14.94$ \\
\hline $49.0-49.5$ & $14.94-15.09$ \\
\hline $49.5-50.0$ & $15.09-15.24$ \\
\hline $50.0-50.5$ & $15.24-15.39$ \\
\hline $50.5-51.0$ & $15.39-15.54$ \\
\hline $51.0-51.5$ & $15.54-15.70$ \\
\hline $51.5-52.0$ & $15.70-15.85$ \\
\hline $52.0-52.5$ & $15.85-16.00$ \\
\hline $52.5-53.0$ & $16.00-16.15$ \\
\hline $53.0-53.5$ & $16.15-16.31$ \\
\hline $53.5-54.0$ & $16.31-16.46$ \\
\hline $54.0-54.5$ & $16.46-16.61$ \\
\hline $54.5-55.0$ & $16.61-16.76$ \\
\hline $55.0-55.5$ & $16.76-16.92$ \\
\hline $55.5-56.0$ & $16.92-17.07$ \\
\hline $56.0-56.5$ & $17.07-17.22$ \\
\hline $56.5-57.0$ & $17.22-17.37$ \\
\hline $57.0-57.5$ & $17.37-17.53$ \\
\hline $57.5-58.0$ & $17.53-17.68$ \\
\hline $58.0-58.5$ & $17.68-17.83$ \\
\hline $58.5-59.0$ & $17.83-17.98$ \\
\hline $59.0-59.5$ & $17.98-18.14$ \\
\hline $59.5-60.0$ & $18.14-18.29$ \\
\hline $60.0-60.5$ & $18.29-18.44$ \\
\hline $60.5-61.0$ & $18.44-18.59$ \\
\hline $61.0-61.5$ & $18.59-18.75$ \\
\hline $61.5-62.0$ & $18.75-18.90$ \\
\hline $62.0-62.5$ & $18.90-19.05$ \\
\hline $62.5-63.0$ & $19.05-19.20$ \\
\hline $63.0-63.5$ & $19.20-19.35$ \\
\hline $63.5-64.0$ & $19.35-19.51$ \\
\hline $64.0-64.5$ & $19.51-19.66$ \\
\hline $64.5-65.0$ & $19.66-19.81$ \\
\hline $65.0-65.5$ & $19.81-19.96$ \\
\hline $65.5-66.0$ & $19.96-20.12$ \\
\hline $66.0-66.5$ & $20.12-20.27$ \\
\hline $66.5-67.0$ & $20.27-20.42$ \\
\hline $67.0-67.5$ & $20.42-20.57$ \\
\hline $67.5-68.0$ & $20.57-20.73$ \\
\hline $68.0-68.5$ & $20.73-20.88$ \\
\hline
\end{tabular}

Sample

Oven-Dry

Weight

(F)

905.86

884.45

924.47

992.14

938.45

958.09

907.59

1017.67

927.60

926.98

945.95

954.55

986.16

822.24

900.50

942.71

913.21

897.17

882.93

920.98

879.39

875.12

846.71

936.04

872.15

880

843.42

897.07

863.17

872.07

772.75

970.49

918.56

861.69

901.34

885.34

906.72

886.11

904.62

854.57

854.76

946.18

813.00
Water Pu Conc (pCi/g) ${ }^{241} \mathrm{Am}$ Conc (pCi/g)

Content \pm Analytical Error \pm Analytical Error

(\%)

4.94

4.78

6.25

5.10

5.30

5.50

5.50

5.75

5.82

4.97

5.82

6.28

6.54

6.04

6.78

6.39

6.49

6.92

6.97

7.57

10.11

11.53

13.64

12.34

16.36

18.76

17.85

13.15

16.33

13.93

9.18

10.28

7.39

6.46

5.70

6.13

5.78

6.41

8.50

6.84

6.62

6.62

6.13
(\%)

ND

ND

ND

$-$

ND

-

ND

ND

-

ND

ND

-

ND

-

ND

ND

-

ND

-

ND

ND

$-$

ND

ND

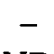

ND

ND

$-$

ND

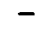

ND

ND

ND
(\%)

ND

ND

ND

ND

-

ND

ND

ND

ND

-

ND

ND

-

ND

-

ND

ND

ND

$-$

ND

ND

ND

ND

-

ND

-

ND

ND

ND 
TABLE B-IV (cont)

Sample Depth Increment

(ft)$$
\begin{aligned}
& 68.5 \\
& 69.0 \\
& 69.5 \\
& 70.0
\end{aligned}
$$

it)

$68.5-69.0$

$69.0-69.5$

$69.5-70.0$

$70.0-70.5$

$70.5-71.0$

$71.0-71.5$

$71.5-72.0$

$72.0-72.5$

$72.5-73.0$

$73.0-73.5$

$73.5-74.0$

$74.0-74.5$

$74.5-75.0$

$75.0-75.5$

$75.5-76.0$

$76.0-76.5$

$76.5-77.0$

$77.0-77.5$

$77.5-78.0$

$78.0-78.5$

$82.5-83.0$

$83.0-83.5$

$83.5-84.0$

$84.0-84.5$

$84.5-85.0$

$85.0-85.5$

$85.5-86.0$

$86.0-86.5$

$86.5-87.0$

$87.0-87.5$

$87.5-88.0$

$88.0-88.5$

$88.5-89.0$

$89.0-89.5$

$89.5-90.0$

$90.0-90.5$

$90.5-91.0$

$91.0-91.5$

$91.5-92.0$

$92.0-92.5$

$92.5-93.0$

$93.0-93.5$

$93.5-94.0$ (m)

$\frac{(\mathrm{m})}{20.88-21.03}$

?1.03-21.18

$21.18-21.34$

$21.34-21.49$

$21.49-21.64$

$21.64-21.79$

$21.79-21.95$

$21.95-22.10$

$22.10-22.25$

$22.25-22.40$

$22.40-22.56$

$22.56-22.71$

$22.71-22.86$

$22.86-23.01$

$23.01-23.16$

$23.16-23.32$

$23.32-23.47$

$23.47-23.62$

$23.62-23.77$

$23.77-23.93$

$25.15-25.30$

$25.30-25.45$

$25.45-25.60$

$25.60-25.76$

$25.76-25.91$

$25.91-26.06$

$26.06-26.21$

$26.21-26.37$

$26.37-26.52$

$26.52-26.67$

$26.67-26.82$

$26.82-26.97$

26.97-27.13

$27.13-27.28$

$27.28-27.43$

$27.43-27.58$

$27.58-27.74$

$27.74-27.89$

$27.89-28.04$

$28.04-28.19$

$28.19-28.35$

$28.35-28.50$

$28.50-28.65$
Sample

Oven-Dry Weight

(g)

957.56

919.64

916.21

887.10

802.23

878.58

900.15

887.38

777.19

856.68

912.29

868.12

832.84

945.89

937.05

870.80

849.38

977.75

886.02

893.64

960.60

900.94

914.17

892.52

945.79

943.99

905.78

836.35

936.38

980.47

902.63

871.63

962.77

934.88

924.35

866.69

1056.42

859.37

954.40

936.70

952.53

956.37

907.86
Water

Content

(\%)

6.15

6.74

6.69

6.67

6.78

6.49

6.59

6.50

6.15

6.75

6.46

6.56

6.30

6.43

6.66

6.29

5.83

6.03

5.62

5.64

7.80

5.86

4.48

4.56

4.55

3.94

3.99

3.69

4.50

4.95

4.41

4.68

4.33

4.76

4.94

4.56

7.28

4.93

4.98

4.81

4.71

5.34

5.03
Pu Cone (pCi/g) ${ }^{241}$ Am Conc (pCi/g) \pm Analytical Error \pm Analytical Error (\%) (\%)

ND

ND

ND

ND

ND

ND

ND

ND ND

ND ND

- $\quad-$

ND ND

$-$

ND ND

ND ND

$-$

ND

$-$

ND

ND

ND

$-$

ND

ND

ND

ND

-

ND

ND

ND

ND

-

ND

ND

-

ND

ND

-

ND

ND

ND

IND

$\overline{N D}$

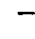

ND 
TABLE B-IV (cont)

\begin{tabular}{|c|c|c|c|c|c|}
\hline \multicolumn{2}{|c|}{ Sample Depth Increment } & \multirow[t]{2}{*}{$\begin{array}{c}\text { Sample } \\
\text { Oven-Dry } \\
\text { Weight } \\
\text { (g) }\end{array}$} & \multirow{2}{*}{$\begin{array}{c}\text { Water } \\
\text { Content } \\
(\%)\end{array}$} & \multirow{2}{*}{$\begin{array}{c}\text { Pu Conc (pCi/g) } \\
\pm \text { Analytical Error } \\
(\%)\end{array}$} & \multirow{2}{*}{$\begin{array}{c}{ }^{241} \text { Am Conc (pCi/g) } \\
\pm \text { Analyticai Error } \\
(\%)\end{array}$} \\
\hline (ft) & (m) & & & & \\
\hline $94.0-94.5$ & $28.65-28.80$ & 868.34 & 5.31 & ND & ND \\
\hline $94.5-95.0$ & $28.80-28.96$ & 913.16 & 4.54 & - & - \\
\hline $95.0-95.5$ & $28.69-29.11$ & 934.26 & 5.45 & ND & ND \\
\hline $95.5-96.0$ & $29.11-29.26$ & 922.81 & 5.66 & - & - \\
\hline $96.0-96.5$ & $29.26-29.41$ & 883.04 & 6.47 & ND & ND \\
\hline $96.5-97.0$ & $29.41-29.57$ & 893.15 & 6.06 & - & - \\
\hline $97.0-97.5$ & $29.57-29.72$ & 960.75 & 5.32 & ND & ND \\
\hline $97.5 \sim 98.0$ & $29.72-29.87$ & 875.88 & 5.17 & - & - \\
\hline $98.0-98.5$ & $29.87-30.02$ & 885.66 & 4.77 & ND & ND \\
\hline $98.5-99.0$ & $30.02-30.18$ & 736.43 & 5.06 & - & - \\
\hline $99.0-99.5$ & $30.18-30.33$ & 954.13 & 4.54 & ND & ND \\
\hline $99.5-100.0$ & $30.33-30.48$ & 935.47 & 4.02 & - & - \\
\hline $100.0-100.5$ & $30.48-30.63$ & 909.34 & 3.82 & ND & ND \\
\hline
\end{tabular}

